\title{
Deciphering the function of canonical Wnt signals in development and disease: conditional loss- and gain-of-function mutations of $\beta$-catenin in mice
}

\author{
Tamara Grigoryan, Peter Wend, Alexandra Klaus, and Walter Birchmeier ${ }^{1}$ \\ Max-Delbück Center for Molecular Medicine, 13125 Berlin, Germany
}

Wnt signaling is one of a handful of powerful signaling pathways that play crucial roles in the animal life by controlling the genetic programs of embryonic development and adult homeostasis. When disrupted, these signaling pathways cause developmental defects, or diseases, among them cancer. The gateway of the canonical Wnt pathway, which contains $>100$ genes, is an essential molecule called $\beta$-catenin (Armadillo in Drosophila). Conditional loss- and gain-of-function mutations of $\beta$ catenin in mice provided powerful tools for the functional analysis of canonical Wnt signaling in many tissues and organs. Such studies revealed roles of Wnt signaling that were previously not accessible to genetic analysis due to the early embryonic lethality of conventional $\beta$-catenin knockout mice, as well as the redundancy of Wnt ligands, receptors, and transcription factors. Analysis of conditional $\beta$-catenin loss- and gain-offunction mutant mice demonstrated that canonical Wnt signals control progenitor cell expansion and lineage decisions both in the early embryo and in many organs. Canonical Wnt signaling also plays important roles in the maintenance of various embryonic or adult stem cells, and as recent findings demonstrated, in cancer stem cell types. This has opened new opportunities to model numerous human diseases, which have been associated with deregulated Wnt signaling. Our review summarizes what has been learned from genetic studies of the Wnt pathway by the analysis of conditional $\beta$ catenin loss- and gain-of-function mice.

That a single cell, the fertilized egg, can generate a complete animal with a wide variety of complex tissues and organs is the most remarkable process in nature. The rise of multicellular animal life was a huge evolutionary step that apparently only happened once, as evidenced by the genomic content of today's species. The molecular foot-

[Keywords: $\beta$-Catenin; development; disease; mouse]

${ }^{1}$ Corresponding author.

E-MAIL wbirch@mdc-berlin.de; FAX 49-30-94062656.

Article is online at http://www.genesdev.org/cgi/doi/10.1101/gad.1686208. prints of evolution can be seen both between species and within them; a small number of signaling pathways are used over and over again, to build similar structures in different organisms as well as to create a wide variety of structures within a single animal's body. Such core signaling pathways include Wnt, Hedgehog, Tgf- $\beta /$ Bmp, Notch, and receptor tyrosine kinases and are widely conserved in vertebrates and invertebrates (for review, see Beddington and Robertson 1999; Jessell and Sanes 2000; Capdevila and Izpisua Belmonte 2001; Logan and Nusse 2004; Schier and Talbot 2005). They act in parallel or in sequence in order to regulate crucial aspects of development and morphogenesis including cellular proliferation, differentiation, cell migration, and apoptosis. Deregulation of these signaling cascades may lead to severe developmental perturbations and lethality. In adult organisms, the same pathways play crucial roles in the maintenance of tissue homeostasis and control stem cell functions. Their dysfunction may lead to pathological conditions such as cancer (for review, see Hunter 1997; Polakis 2000; Chari and McDonnell 2007; Dreesen and Brivanlou 2007). Almost three decades of interdisciplinary research have revealed the physiological function of these pathways in a spectrum of model organisms including hydra, worms, flies, fish, frogs, mice, and humans. Mice have proven to be a particularly powerful model to study molecular mechanisms of development and disease. This is due to the close evolutionary relationship of rodents and humans, similarities in physiological and pathophysiological mechanisms in mice and man, and the large repertoire of genetic techniques available to assess gene functions in mice.

Wnt signaling is an ancient and highly conserved pathway (for review, see Logan and Nusse 2004; Clevers 2006; Klaus and Birchmeier 2008). The molecular components of Wnt signaling and the mechanisms of Wnt signal transduction have been elucidated through genetic and biochemical experiments in various model organisms and in cultured cells. In 1982, Nusse and Varmus identified the proto-oncogene int-1 (integration-1) as a preferential site for proviral integration of the mouse mammary tumor virus (MMTV) in a mouse model of 
mammary cancer (Nusse and Varmus 1982). Int-1 turned out to be the mammalian homolog of the genetically characterized segment polarity gene in Drosophila, wingless (wg) (Nusslein-Volhard and Wieschaus 1980; Cabrera et al. 1987; Rijsewijk et al. 1987). The name currently used for these molecules, "Wnt," is a fusion of the two terms, "int" and "wingless," and refers to the extracellular ligands of the pathway (Nusse et al. 1991). In the late 1980s and early 1990s, many components of the Wnt signaling cascade were discovered through other Drosophila mutations, which produced segment polarity defects like wingless, such as the cytoplasmatic and nuclear signal transducing molecules Disheveled, Armadillo/ $\beta$-catenin, Pangolin/Lef1, and the characterization of the epistatic relationship between the genes that encode these molecules (McMahon and Moon 1989; Dominguez et al. 1995; Guger and Gumbiner 1995; Behrens et al. 1996). Xenopus oocytes provided an additional, widely used assay to study components of the Wnt signaling system. The injection of Xenopus oocytes with RNA that encodes components regulating the Wnt pathway in a positive manner-e.g., Wnt $1, \beta$-catenin, dominant-negative GSK3 $\beta$, or Lef1-resulted in axis duplication (McMahon and Moon 1989; Dominguez et al. 1995; Guger and Gumbiner 1995; Behrens et al. 1996), whereas injection of the RNA of Wnt signaling inhibitors such as Axin1 or Axin2/Conductin resulted in a loss of the primary body axis (Zeng et al. 1997; Behrens et al. 1998). Wnt signaling's contribution to the establishment of the anterior-posterior (A-P) axis was analyzed by gene ablation in the mouse, which demonstrated the conserved function of Axin 1 and $\beta$-catenin in the Wnt pathway (Zeng et al. 1997; Huelsken et al. 2000).

Our current knowledge of the molecular components of the Wnt signaling cascade is summarized in Figure 1. The signal is initiated by Wnt ligands (there are $19 \mathrm{Wnt}$ genes in the human genome). The secretion and posttranslational modifications of Wnt ligands are accomplished by the retromer complex and accompanying molecules, such as porcupine and Wntless (Wls) (for review, see Coudreuse and Korswagen 2007; Hausmann et al. 2007). Wnts bind to and activate specific receptors, members of the Frizzled and LRP families (for review, see Mikels and Nusse 2006; Huang and He 2008). Inhibitors of Wnt-receptor interactions are secreted frizzledrelated proteins (sFRP), Dickkopfs (Dkk), and Wntinhibitory factor (WIF) (Finch et al. 1997; Leyns et al. 1997; Hsieh et al. 1999). The signal transduction cascades downstream from the Wnt receptors comprise a large number of molecules that signal through different branches and effector molecules (see the Wnt genes homepage at http://www.stanford.edu/ rnusse/ Wntwindow.html). These include the canonical Wnt/ $\beta$-catenin branch (Fig. 1, blue and red in the center), and the noncanonical Jun kinase and the Wnt/Ca ${ }^{2+}$ branches (Fig. 1, green and orange on the right; Veeman et al. 2003; Kuhl 2004; Logan and Nusse 2004; Seifert and Mlodzik 2007). Central to canonical Wnt signaling is the control of the stability of its core component, $\beta$-catenin (Fig. 1, red; Munemitsu et al. 1995). $\beta$-Catenin has dual functions and can form a stable complex with the cell adhesion molecules of the cadherin family, participating in formation of adherens junctions (Fig. 1, top left and right; Takeichi 1991; Kemler 1993; Hulsken et al. 1994; Huber et al. 1997). In the absence of Wnt signals, $\beta$-catenin that is not bound in a complex with cadherins is captured by a destruction complex containing GSK $3 \beta$, Axin/Conductin, and APC, where it is first phosphorylated, then ubiquitinated on $\mathrm{N}$-terminal sequences, and subsequently targeted to proteosomes that mediate its degradation (Fig. 1, left; Aberle et al. 1994; Salomon et al. 1997; Behrens et al. 1998; Marikawa and Elinson 1998; Liu et al. 2002; Yanagawa et al. 2002). In contrast, in the presence of the Wnt ligands, the destruction complex is disassembled through phosphorylation of LRP5/6 and binding of Axin to LRP, which prevents $\beta$-catenin degradation (Mao et al. 2001; Bilic et al. 2007; Schwarz-Romond et al. 2007). Free $\beta$-catenin (Fig. 1, red in the center) can then enter the nucleus, where it binds to the Tcf/Lef family of transcription factors, replacing the transcriptional inhibitor Groucho, and activates transcription of Wnt target genes (Behrens et al. 1996; Molenaar et al. 1996; Zeng et al. 1997; Roose et al. 1998; Tetsu and McCormick 1999; for review, see Nelson and Nusse 2004; Clevers 2006; Willert and Jones 2006; see Wnt genes homepage http://www.stanford.edu/ rnusse/wntwindow.html).

In line with the initial discovery of Wnt1 in mouse mammary neoplasias, the constitutive activation of Wnt signaling causes tumor formation and progression in humans. Gain-of-function mutations of activators of the Wnt pathway can have oncogenic activity, whereas lossof-function mutations of inhibitors of Wnt signaling can lead to a loss of tumor suppressor activity. For instance, mutations in the $\beta$-catenin gene that enhance its stability, or mutations in genes that control $\beta$-catenin stability like APC, the Axins, or E-cadherin, cause various types of human cancers (for review, see Birchmeier and Behrens 1994; Bienz and Clevers 2000; Polakis 2000; Fodde and Brabletz 2007).

Over nearly two decades, gene targeting techniques have provided ever deeper insights into Wnt activity and functions. In mice, these methods are based on homologous recombination in embryonic stem cells and allow the introduction of mutations into any gene (work for which Mario R. Capecchi, Martin J. Evans, and Oliver Smithies were awarded the Nobel Prize in Physiology or Medicine in 2007) (Evans and Kaufman 1981; Doetschman et al. 1987; Thomas and Capecchi 1990). These mutant embryonic stem cells are then used to produce mice that carry the mutant allele. The first targeted mutations in Wnt genes of mice, today commonly referred to as "knockout mouse models," were indeed reported in 1990: In parallel, the laboratories of Mario Capecchi and of Andy McMahon and Alan Bradley had introduced null mutations of the int-1 (Wnt1) gene, which produced developmental changes in the midbrain and cerebellum (McMahon and Bradley 1990; Thomas and Capecchi 1990). During the 1990s, knockout mice carrying targeted mutations in genes encoding newly identified members of the Wnt family of ligands were 


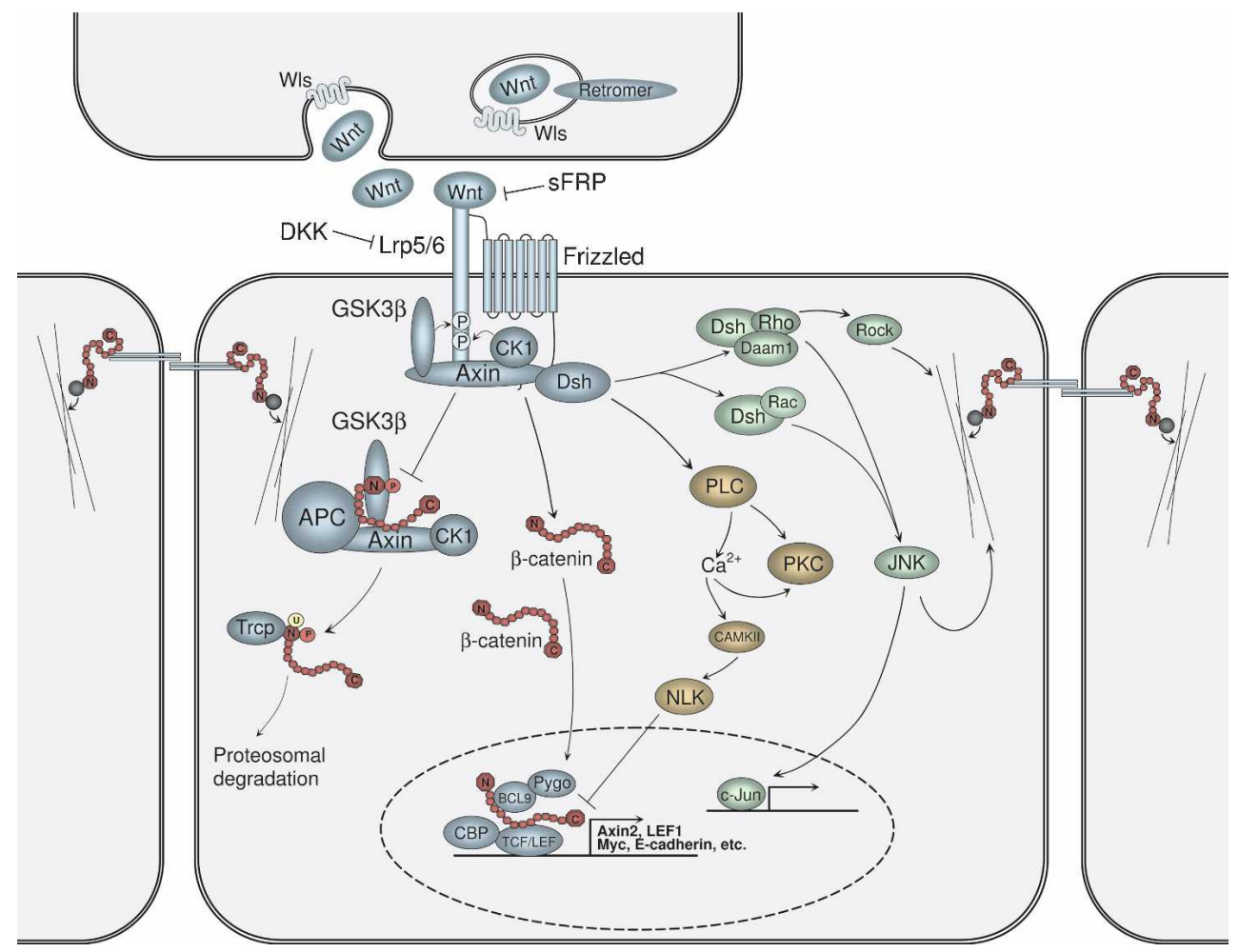

Figure 1. Scheme of the Wnt signaling pathway. The Wnt glycoproteins are produced by the neighboring cells and secreted in a process that involves many components, such as a multiprotein retromer complex, and the multispanning transmembrane protein Wntless (Wls). The secreted Wnt ligands bind to the receptors of the seven-membrane-spanning Frizzled family and single-spanning LRP family. Secreted factors like secreted Frizzled-related proteins (sFRPs) bind to Wnts and block the interaction with Frizzled receptors. Dickkopf antagonizes Wnt signaling by blocking LRP receptors. Three main branches are activated downstream from the Wnt signals: canonical Wnt/ $\beta$-catenin signaling (blue and red, in the center and on the left), and the noncanonical Jun kinase and $\mathrm{Wnt} / \mathrm{Ca}^{2+}$ pathways (green and orange on the right). The central component of the canonical Wnt signaling is $\beta$-catenin (red). (Left and right) In the absence of the Wnt signals, $\beta$-catenin forms a stable complex with E-cadherin and participates in adherens junction formation. (Left) Excess $\beta$-catenin is captured by a destruction complex containing GSK3 $\beta$, Axin1, Axin2/Conductin, and APC, where it gets $\mathrm{N}$-terminally phosphorylated and, following ubiquitination by $\beta$-Trcp, targeted to proteosome-mediated degradation. In contrast, in the presence of the Wnt ligands, disassembly of the destruction complex occurs through phosphorylation of LRP5/6 by GSK3 $\beta$ and $\mathrm{CK} 1 \alpha$, and binding of Axin to LRP, thereby preventing $\beta$-catenin degradation. Free cytoplasmatic $\beta$-catenin can then enter the nucleus, where it forms a transcriptionally active complex with Tcf/Lef family of transcription factors, by replacing Grouchos from chromatin, and interacting with other coactivators like CBP, BCL9, and Pygopus. The three pathways branch at the level of Dishevelled (Dsh) protein. In the noncanonical Jun kinase pathway, Dsh via Daaml, is connected to downstream effectors, such as Rho, and regulates cytoskeletal organization and cell polarity. The $\mathrm{Wnt} / \mathrm{Ca}^{2+}$ pathway leads to the release of intracellular calcium, and involves activation of Phospholipase $\mathrm{C}$ (PLC) and protein kinase $\mathrm{C}(\mathrm{PKC}) . \mathrm{Ca}^{2+}$ can activate Calmodulin-dependent protein kinase $\mathrm{C}$ (CaMKII), and Nemo-like kinase (NLK), and suppress canonical Wnt signaling.

generated (Stark et al. 1994; Takada et al. 1994; Fritzsch et al. 1995; Parr and McMahon 1995; Yamaguchi 2001; for review, see van Amerongen and Berns 2006). These studies revealed an important role of Wnt genes in development of additional tissues including the mesoderm, kidney, and extremities. The fact that compound mutations of these genes often exhibited stronger and earlier phenotypes than the single mutations suggested a functional redundancy between the different Wnt genes (Ikeya et al. 1997; Ikeya and Takada 1998; Yamaguchi et al. 2005). Identification of $\beta$-catenin as the one nonredundant and central component of the canonical Wnt pathway, a bottleneck through which all signals pass, made it a particularly attractive target for genetic manipulation. Null mutations of $\beta$-catenin result in gastrulation defects and embryonic lethality (Haegel et al.
1995; Huelsken et al. 2000; Morkel et al. 2003). Such mutant embryos failed to form an A-P axis at embryonic day 6 (E6) and did not generate mesoderm at E7. Apparently, $\beta$-catenin does not play an essential earlier role in Wnt signaling; e.g., in embryonic stem cells or blastocyst formation (but see also Doble et al. 2007; Cole et al. 2008). Importantly, $\beta$-catenin-deficient embryos preserved intact adherens junctions, since plakoglobin $(\gamma$ catenin), another member of armadillo protein family, can take over the role of $\beta$-catenin in cell adhesion (Huelsken et al. 2000). However, early constitutive activation of $\beta$-catenin in mouse embryos leads to a change of the cell fate in the epiblast (Morkel et al. 2003; Kemler et al. 2004). We should also mention that the use of the various Wnt reporter mice generated by several groups was an important help to the field, and those mice were 
used extensively to monitor endogenous Wnt signaling activity (DasGupta and Fuchs 1999; Cheon et al. 2002; Lustig et al. 2002; Soshnikova et al. 2003; Bridgewater et al. 2008).

The ability to mutate genes in the mouse in a temporal and tissue-specific manner by conditional gene mutation, techniques developed by Klaus Rajewsky and collaborators (Gu et al. 1994), has permitted both overcoming the early embryonic lethality of the $\beta$-catenin mutation and accurate studies of the role of canonical Wnt signaling in various tissues at many developmental stages. This strategy relies on the introduction of recombinase recognition sites (LoxP or Frt) that flank the target gene or parts of it. These recognition sites are, for instance, inserted into intronic sequences of a gene in such a way that in the absence of the recombinase (Cre or Flp), the normal gene function is not altered. However, tissuespecific expression of Cre or Flp leads to a recombination event, resulting in the excision of the flanked ("floxed" or "Flrted") part of the gene and, as a consequence, the alteration or elimination of gene function (for review, see Lewandoski 2001; Yu and Bradley 2001). In the last de- cade, two different approaches have been applied in order to conditionally mutate $\beta$-catenin in mice: The first, a deletion of several exons of the $\beta$-catenin gene, resulted in tissue-specific null mutations and loss of canonical Wnt signaling (Fig. 2a). The second, a deletion of a single exon of the $\beta$-catenin gene, exon 3 , resulted in the production of an $\mathrm{N}$-terminally truncated and stabilized form of the protein, which constitutively activates Wnt signaling (Fig. 2b). In order to generate conditional null mutations of $\beta$-catenin, two alleles were generated in which about a third of the $\beta$-catenin gene is flanked by loxP sites (Fig. 2a): in the $\beta$-catenin ${ }^{\text {Wbm/flox }}$ allele produced by our laboratory (Jackson laboratory nomenclature: Ctnnb1 ${ }^{\mathrm{tm} 4 / \mathrm{Wbm}}$ ), the loxP sites flank exons 3-6 (Huelsken et al. 2001); in the $\beta$-catenin ${ }^{\mathrm{Kem} / \text { flox }}$ allele produced by Kemler's laboratory (Brault et al. 2001) (Ctnnb1 $\left.{ }^{\mathrm{tm} 2 / \mathrm{Kem}}\right)$, loxP sites flank exons 2-6. Cre-mediated recombination produced loss-of-function mutations of $\beta$-catenin in a tissue-specific manner (Fig. 2c). In order to generate a conditional gain-of-function mutation of $\beta$-catenin, the Taketo laboratory introduced loxP sites that flank exon 3, $\beta$-catenin ${ }^{\text {Mmt/flox }}\left(\right.$ Ctnnb $^{\text {tm1/Mmt }}$ ) (Fig. 2b; Harada et

\section{a}
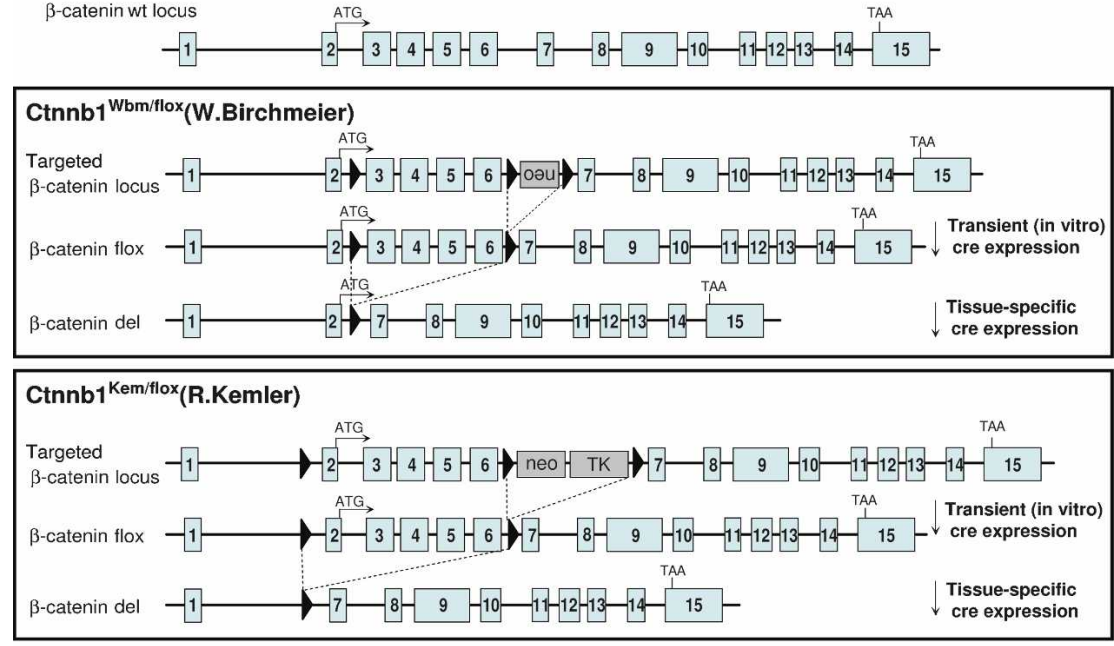

b

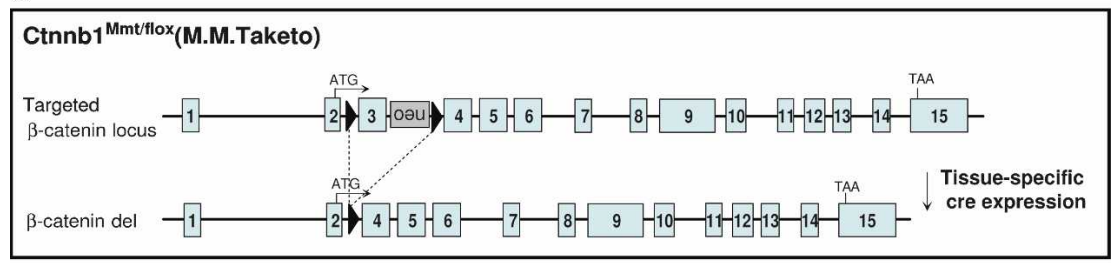

C

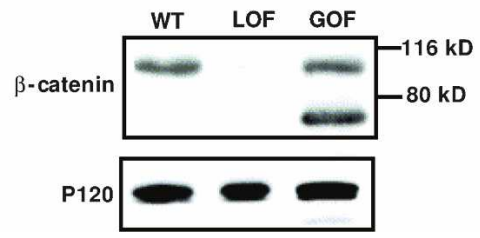

d

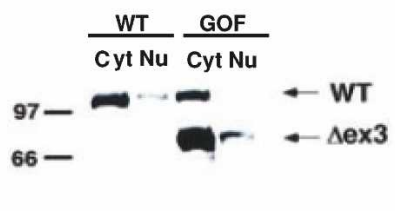

Figure 2. Introduction of conditional loss- and gain-of-function mutations into the $\beta$-catenin locus. (a) Genomic locus of the $\beta$-catenin gene and the two strategies of generation of the $\beta$-catenin loss-of-function alleles. In one strategy, loxP sites flank exons 3-6, to generate the Ctnnb $1^{\text {Wbm/flox }}$ allele; in the second strategy, loxP sites flank exons 2-6 to generate the Ctnnb1 ${ }^{\mathrm{Kem} / \text { flox }}$ allele. In both cases, the floxed parts encode the $\mathrm{N}$-terminal domain and the Armadillo repeats 1-4 of the $\beta$-catenin protein. Transient expression of cre recombinase results in excision of the neo resistance cassette. Subsequently, tissue-specific cre expression leads to excision of the floxed exons, frameshift mutations, and production of a null-allele (see in $c$, cf. wild type with LOF). (b) Generation of the $\beta$-catenin gain-of-function allele. LoxP sites flank exon 3 , which encodes phosphorylation sites targeted by GSK3 $\beta$. Tissue-specific cre expression leads to excision of exon 3 and in-frame splicing on exons 2 and 4 , thus resulting in expression of a protein that escapes the degradation. $(c, d)$ Western blot analysis showing tissue-specific recombination of the targeted loci. In the conditional lossof-function mutant, no $\beta$-catenin protein can be detected, whereas in the gain-offunction mutants, a shortened $\beta$-catenin variant is produced (cf. wild type, LOF, and GOF). On the right, the expression of the mutant $\beta$-catenin protein after cre-mediated recombination in cytoplasmic (Cyt) and nuclear $(\mathrm{Nu})$ fractions of the recombinant embryonic stem cells is shown. (WT) Wild type; (LOF) loss-of-function allele; (GOF) gain-of-function allele. $d$ was reprinted with permission from Macmillan Publishers Ltd: Harada et al. (1999), (C) 1999; and $c$ was reprinted from Zechner et al. (2003) with permission from Elsevier. 
al. 1999). Exon 3 of the $\beta$-catenin gene encodes the $\mathrm{N}$ terminal part of the protein containing serine $(S)$ and threonine $(\mathrm{T})$ residues $(\mathrm{S} 45, \mathrm{~T} 41, \mathrm{~S} 37, \mathrm{~S} 33)$ that are phosphorylated by CK1 $\alpha$ and GSK3 $\beta$ (Amit et al. 2002; Liu et al. 2002; Yanagawa et al. 2002). Cre-mediated recombination excises exon 3 and leads to an in-frame fusion of exon 2 and 4 sequences, which encodes a shortened version of $\beta$-catenin lacking $\mathrm{N}$-terminal phosphorylation and ubiquitination sites (Fig. 2c,d; Harada et al. 1999; Zechner et al. 2003). These alleles, which allow conditional inhibition (loss-of-function) or activation (gain-offunction) of $\mathrm{Wnt} / \beta$-catenin signaling, provided powerful tools to analyze Wnt functions in mammalian development (Table 1).

\section{Wnt/ß-catenin signaling in skin and teeth}

By the mid- and end-1990s, several lines of evidence indicated a role of $\mathrm{Wnt} / \beta$-catenin in development of the skin and skin appendages. The epidermis forms the outermost layer of the mammalian skin. Progenitor cells in the basal layer of the epidermis constantly proliferate, ensuring the renewal of the epithelium. In addition to these epidermal progenitors, the bulge attached to the hair follicles is a niche for skin stem cells. These are able to contribute to all epithelial cell types of the skin appendages; e.g., hair follicles and glands (Fig. 3a, stem cells are marked with $\mathrm{K} 15$ and $\beta 1$ integrin probes, arrows; Huelsken et al. 2001). After wounding, bulge stem cells contribute in addition to the newly formed epidermal epithelium (for review, see Paus and Foitzik 2004; Blanpain and Fuchs 2006). Several Wnt genes are expressed in the skin (Wang and Shackleford 1996; Saitoh et al. 1998; for review, see Millar et al. 1999). Early experiments, in which Wnt3, Lef1, or activated $\beta$-catenin were overexpressed in the skin epithelium, had indicated a role of the Wnt/ $\beta$-catenin pathway in development of the hair follicles (Zhou et al. 1995; Gat et al. 1998; Millar et al. 1999; Kishimoto et al. 2000). In addition, gene ablation had demonstrated an essential role of Lef1 in formation of hair, whiskers, and other epidermal appendages (van Genderen et al. 1994). Conversely, one-third of human sebaceous gland tumors carry inactivating mutations of Lef1, indicating that Wnt signaling activity needs to be repressed for proper sebaceous gland development (Takeda et al. 2006).

By conditional mutation of $\beta$-catenin in the skin, using cre driven by the cytokeratin $(\mathrm{K}) 14$ promoter, we showed that canonical Wnt signals are crucial for the generation of hair follicles (Table 1 ; Huelsken et al. 2001). The epidermis develops correctly, but the skin of the mutant mice becomes naked. Instead of hair, unusual cyst-like structures appeared in the skin of these mice (Fig. 3b). The multilayered epithelium surrounding the cysts still contained stem cells (stained with K15 and $\beta 1$ integrin, arrows in Fig. $3 b$ ), and was positive for epidermal markers but negative for hair follicle markers (Huelsken et al. 2001). Postnatal deletion of $\beta$-catenin leads to loss of quiescence and stem cell character of the bulge stem cells (Lowry et al. 2005). Altogether, these data show that Wnt/ $\beta$-catenin signals control the cell fate of the bulge stem cells: Such signals are required for follicular but not epidermal differentiation (see scheme in Fig. 3e). Moreover, transgenic expression of dominantnegative Lef1 also resulted in the formation of cysts instead of hair (Merrill et al. 2001; Niemann et al. 2002). A similar phenotype-i.e., a lack of hair and other epidermal appendages, such as teeth and mammary glandswas observed after ectopic expression of the Wnt inhibitor Dkk1 in the skin (Andl et al. 2002). Finally, Wnt signals have also been found to be essential for de novo hair follicle formation after wounding (Ito et al. 2007). A converse phenotype, accelerated and excessive formation of hair placodes, was observed when a conditional gain-of-function mutation of $\beta$-catenin was introduced by K14 cre in the skin (Närhi et al. 2008). Such animals display densely packed hair follicles with little or no interfollicular epidermis (Fig. 3c,d). This is in line with a previous report of transgenic overexpression of $\Delta \mathrm{N}-\beta$ catenin in the skin; i.e., constitutively active $\beta$-catenin, which resulted in a de novo formation of hair follicles and in the generation of hair follicle tumors (Gat et al. 1998; Chan et al. 1999). That $\beta$-catenin plays a minor role in epidermal development, in contrast to hair, was corroborated using cultured epidermal keratinocytes isolated from the skin of $\beta$-catenin ${ }^{\text {Kemflox }}$ mice, in which the loss-of-function mutation was introduced by Adenovirus-mediated gene transfer of cre (Posthaus et al. 2002). In such cells, proliferation, cell cycle progression, and expression of CyclinD1 were similar to the processes in control cells. Furthermore, $\beta$-catenin-null mutant keratinocytes remained adhesion-competent, due to the functional substitution of $\beta$-catenin by plakoglobin $(\gamma$ catenin). More recently, interactions between Wnt and Bmp signaling have been described as essential in the control of the skin stem cell niche (Zhang et al. 2006; Kobielak et al. 2007). The conditional ablation of Bmp receptor 1a (BmpRla) resulted in increased canonical Wnt signaling, stem cell overproliferation and expansion of the bulge, and loss of quiescent cells. Oscillating expression of Bmps in normal skin regulate oscillations in Wnt signaling in cases such as when Bmp levels in the dermis are high, Wnt signaling activity is low and vice versa (Plikus et al. 2008). The oscillations of Bmp and Wnt signaling ensure periodic activation of the bulge stem cells and allow the coordinated hair differentiation during the hair cycle. Finally, the function of Wnt $/ \beta$ catenin signaling has also been studied in the skin mesenchyme by conditional loss- and gain-of-function mutations of $\beta$-catenin, using an engrailed-1 cre or HoxB6 cre allele (Atit et al. 2006; Ohtola et al. 2008). This demonstrated an essential role of canonical Wnt signals in the specification of the dermis (Table 1).

Loss- and gain-of-function mutations of $\beta$-catenin, using K14 cre, have also allowed the analysis of canonical Wnt signals in the development of teeth, another epidermal appendage (Table 1; Järvinen et al. 2006; Liu et al. 2008). Canonical Wnt signals are required in the epithelium at several steps during the formation of teeth, first at an early stage for proper tooth bud development, and 
Table 1. Loss- and gain-of-function mutations of $\beta$-catenin in mice

\begin{tabular}{|c|c|c|c|c|c|}
\hline Organ $^{a}$ & Cre line & Cre expression & $\beta$-catenin & Phenotype & References \\
\hline \multirow[t]{7}{*}{$\begin{array}{l}\text { Bone/ } \\
\text { cartilage }\end{array}$} & $\begin{array}{l}\text { Prxl cre } \\
\text { Dermol cre }\end{array}$ & $\begin{array}{l}\text { Osteo- } \\
\text { chondroprogenitors }\end{array}$ & LOF & $\begin{array}{l}\text { Reduced osteoblastogenesis, } \\
\text { increased chondrogenesis }\end{array}$ & \multirow{7}{*}{$\begin{array}{l}\text { Akiyama et al. 2004; Guo } \\
\text { et al. 2004; Day et al. } \\
\text { 2005; Hill et al. 2005; } \\
\text { Glass et al. 2005; } \\
\text { Rodda and McMahon } \\
2006\end{array}$} \\
\hline & Col2al cre & & GOF & Increased osteoblastogenesis, & \\
\hline & \multirow[t]{3}{*}{ Colla cre } & \multirow{3}{*}{$\begin{array}{l}\text { Osteoblast } \\
\text { progenitors }\end{array}$} & & reduced chondrogenesis & \\
\hline & & & LOF & $\begin{array}{l}\text { Low bone mass and high } \\
\text { resorption }\end{array}$ & \\
\hline & & & GOF & $\begin{array}{l}\text { Increased bone mass and low } \\
\text { resorption }\end{array}$ & \\
\hline & \multirow[t]{2}{*}{ Osxl-GFP cre ${ }^{\mathrm{b}}$} & \multirow{2}{*}{$\begin{array}{l}\text { Osteoblast } \\
\text { progenitors }\end{array}$} & LOF & Defective osteoblast maturation & \\
\hline & & & GOF & Accelerated osteoblast maturation & \\
\hline \multirow[t]{9}{*}{ CNS } & \multirow[t]{2}{*}{ Brn 4 cre } & \multirow[t]{2}{*}{ CNS } & LOF & $\begin{array}{l}\text { Reduction of the progenitor pool, } \\
\text { loss of } \mathrm{dI} 2 \text { and } \mathrm{dI} 3 \text { interneurons }\end{array}$ & \multirow[t]{2}{*}{$\begin{array}{l}\text { Ille et al. 2007; Zechner } \\
\text { et al. 2003, } 2007\end{array}$} \\
\hline & & & GOF & $\begin{array}{l}\text { Expansion of the progenitor pool, } \\
\text { expansion of dI } 2 \text { and dI } 3 \\
\text { interneurons }\end{array}$ & \\
\hline & POMC cre ${ }^{c}$ & $\begin{array}{l}\text { Cerebral cortex and } \\
\text { hippocampus }\end{array}$ & LOF & $\begin{array}{l}\text { Abnormal neuronal maturation } \\
\text { and dendritic morphology }\end{array}$ & Gao et al. 2007 \\
\hline & Nestin cre & Cerebellum & LOF & $\begin{array}{l}\text { Mid-brain and cerebellum } \\
\text { abnormalities }\end{array}$ & $\begin{array}{l}\text { Schuller and Rowitch } \\
2007\end{array}$ \\
\hline & Emx 1 cre & Telencephalon & LOF & Increased seizure susceptibility & Campos et al. 2004 \\
\hline & D6 cre & $\begin{array}{l}\text { Cerebral cortex and } \\
\text { hippocampus }\end{array}$ & LOF & $\begin{array}{l}\text { Impaired proliferation of } \\
\text { hippocampus progenitors }\end{array}$ & Machon et al. 2003 \\
\hline & HSA cre ${ }^{\mathrm{d}}$ & Myotome & LOF & $\begin{array}{l}\text { Impaired differentiation of } \\
\text { neuron-muscular junctions }\end{array}$ & Li et al. 2008 \\
\hline & \multirow[t]{2}{*}{ Nes8 cre } & \multirow[t]{2}{*}{ Telencephalon } & LOF & $\begin{array}{l}\text { Down-regulation of dorsal } \\
\text { markers, up-regulation of ventral } \\
\text { markers }\end{array}$ & \multirow[t]{2}{*}{ Backman et al. 2005} \\
\hline & & & GOF & $\begin{array}{l}\text { Up-regualtion of dorsal markers, } \\
\text { down-regulation of ventral } \\
\text { markers }\end{array}$ & \\
\hline \multirow[t]{2}{*}{ Ear } & \multirow[t]{2}{*}{ Pax2 cre } & \multirow[t]{2}{*}{ Otic precursors } & LOF & Reduction of the otic placode & \multirow[t]{2}{*}{ Ohyama et al. 2006} \\
\hline & & & GOF & $\begin{array}{l}\text { Expansion of the otic placode at } \\
\text { the expense of epidermis }\end{array}$ & \\
\hline \multirow[t]{5}{*}{ Eye } & \multirow[t]{2}{*}{ Lens cre } & \multirow[t]{2}{*}{ Lens surface ectoderm } & LOF & $\begin{array}{l}\text { Abnormal lens morphology, } \\
\text { ectopic lens }\end{array}$ & \multirow{3}{*}{$\begin{array}{l}\text { Smith et al. 2005; Miller } \\
\text { et al. 2006; Kreslova et } \\
\text { al. } 2007\end{array}$} \\
\hline & & & GOF & Loss of lens structure & \\
\hline & LR cre ${ }^{\mathrm{e}}$ & $\begin{array}{l}\text { Lens ectoderm, } \\
\text { partially in retina }\end{array}$ & LOF & $\begin{array}{l}\text { Abnormal eye morphology, ectopic } \\
\text { lens in the periocular area }\end{array}$ & \\
\hline & Six 3 cre & Developing retina & LOF & $\begin{array}{l}\text { Disruption of the retinal laminar } \\
\text { structure, loss of retinal } \\
\text { progenitor orientation and } \\
\text { arrangement }\end{array}$ & Fu et al. 2006 \\
\hline & $\alpha$ cre & $\begin{array}{l}\text { Anterior-peripheral } \\
\text { retina }\end{array}$ & GOF & $\begin{array}{l}\text { Loss of proper retinal structure, } \\
\text { transdifferentiation of neural } \\
\text { cells into pigmented cells }\end{array}$ & \\
\hline \multirow[t]{8}{*}{ Heart } & \multirow[t]{2}{*}{ Mespl cre $^{f}$} & \multirow[t]{2}{*}{ All heart progenitors } & LOF & $\begin{array}{l}\text { Defects in second heart field } \\
\text { proliferation }\end{array}$ & \multirow{8}{*}{$\begin{array}{l}\text { Kioussi et al. 2002; } \\
\text { Lickert et al. 2002; } \\
\text { Liebner et al. 2004; } \\
\text { Chen et al. 2006; } \\
\text { Ai et al. 2007; Baurand } \\
\text { et al. 2007; Cohen et al. } \\
\text { 2007; Klaus et al. 2007; } \\
\text { Kwon et al. 2007; Lin } \\
\text { et al. 2007; Qu et al. } \\
\text { 2007; Qyang et al. }\end{array}$} \\
\hline & & & GOF & Disrupted heart tube formation & \\
\hline & Nkx2.5 cre & All heart precursors & LOF & Defects in outflow tract and right & \\
\hline & $\operatorname{Sm} 22 \alpha$ cre $^{g}$ & \multirow{2}{*}{$\begin{array}{l}\text { Cardiomyocytes and } \\
\text { endothelial cells } \\
\text { Second heart field }\end{array}$} & GOF & $\begin{array}{l}\text { ventricle } \\
\text { Fnlarged size of second heart field }\end{array}$ & \\
\hline & Isl1 cre & & & $\begin{array}{l}\text { derivatives due to enhanced } \\
\text { proliferation of the second heart } \\
\text { field }\end{array}$ & \\
\hline & \multirow[t]{2}{*}{$\begin{array}{l}\text { Mef2c-AHF } \\
\text { cre }^{\text {h }}\end{array}$} & \multirow[t]{2}{*}{ Second heart field } & LOF & $\begin{array}{l}\text { Defects in outflow tract and right } \\
\text { ventricle }\end{array}$ & \\
\hline & & & GOF & $\begin{array}{l}\text { Shortened right ventricle, dense } \\
\text { outflow tract myocardium }\end{array}$ & \\
\hline & $\alpha \mathrm{MHC}$ cre & Cardiomyocytes & Het-LOF & $\begin{array}{l}\text { Attenuated cardiac hypertrophy } \\
\text { following pathological stress }\end{array}$ & \\
\hline
\end{tabular}


Table 1. (continued)

\begin{tabular}{|c|c|c|c|c|c|}
\hline Organ $^{a}$ & Cre line & Cre expression & $\beta$-catenin & Phenotype & References \\
\hline & Wnt1 cre & $\begin{array}{l}\text { Cardiac neural crest } \\
\text { cells }\end{array}$ & LOF & $\begin{array}{l}\text { Defects in outflow tract } \\
\text { remodeling }\end{array}$ & \\
\hline & Tie2 cre & Endothelial cells & LOF & $\begin{array}{l}\text { Defects in endocardial cushion } \\
\text { formation }\end{array}$ & \\
\hline & GATA5 cre & Epicardium & LOF & Impaired coronary artery formation & \\
\hline & K19 cre & Embryonic endoderm & LOF & Multiple heart formation & \\
\hline & $\alpha M H C$ cre $^{i}$ & Cardiomyocytes & LOF & Cardiac hypertrophy & \\
\hline \multirow{4}{*}{$\begin{array}{l}\text { Hemato- } \\
\text { poietic } \\
\text { system }\end{array}$} & Lck cre & Thymocytes & GOF & Impaired T-cell development & \multirow{4}{*}{$\begin{array}{l}\text { Gounari et al. 2001; } \\
\text { Mulroy et al. 2003; Xu e } \\
\text { al. 2003; Scheller et al. } \\
\text { 2006; Zhao et al. 2007; } \\
\text { Jeannet et al. 2008; Koch } \\
\text { et al. 2008 }\end{array}$} \\
\hline & Mx cre & $\begin{array}{l}\text { Hematopoeitic } \\
\text { precursors }\end{array}$ & LOF & $\begin{array}{l}\text { Impaired HSC self-renewal, no } \\
\text { effect in combination with } \\
\text { plakoglobin }\end{array}$ & \\
\hline & & & GOF & Loss of quiescent HSCs & \\
\hline & Vav cre & $\begin{array}{l}\text { Hematopoeitic } \\
\text { precursors }\end{array}$ & LOF & Prevention of CML development & \\
\hline \multirow[t]{3}{*}{ Intestine } & $\begin{array}{l}\text { Cyp } 450 \text { cre } \\
\text { Villin cre } \text { crTj }^{\mathrm{ERT}}\end{array}$ & Intestinal epithelium & LOF & Loss of crypts & \multirow{2}{*}{$\begin{array}{l}\text { Harada et al. 1999; Ireland } \\
\text { et al. 2004; Fevr et al. } \\
2007\end{array}$} \\
\hline & $\begin{array}{l}\text { K19 cre } \\
\text { Fabpl cre }\end{array}$ & & GOF & Intestinal polyposis & \\
\hline & Bmil cre & Intestinal crypts & GOF & Intestinal adenoma formation & $\begin{array}{l}\text { Sangiorgi and Capecchi } \\
2008\end{array}$ \\
\hline \multirow[t]{3}{*}{ Kidney } & Six2GFP cre & Kidney mesenchyme & $\begin{array}{l}\text { LOF } \\
\text { GOF }\end{array}$ & $\begin{array}{l}\text { Reduced kidney size and branching } \\
\text { Increased kidney size, absent } \\
\text { branching }\end{array}$ & \multirow[t]{3}{*}{$\begin{array}{l}\text { Park et al. 2007; } \\
\text { Bridgewater et al. 2008; } \\
\text { Marose et al. } 2008\end{array}$} \\
\hline & Hoxb7 cre & Kidney epithelium & LOF & Hypoplasia, loss of UB & \\
\hline & & & GOF & Increased differentiation & \\
\hline \multirow[t]{5}{*}{ Limb } & Brn4 cre & AER & LOF & $\begin{array}{l}\text { Limb malformations, defects in } \\
\mathrm{D}-\mathrm{V} \text { and } \mathrm{P}-\mathrm{D} \text { patterning }\end{array}$ & \multirow[t]{2}{*}{ Soshnikova et al. 2003} \\
\hline & & & GOF & $\begin{array}{l}\text { Enlarged limbs, D-V patterning } \\
\text { defects }\end{array}$ & \\
\hline & Msx 2 cre & AER & LOF & $\begin{array}{l}\text { Loss of hindlimbs, truncated } \\
\text { forelimbs, disrupted D-V } \\
\text { patterning }\end{array}$ & Barrow et al. 2003 \\
\hline & Prxl cre & Limb mesenchyme & LOF & Shortened limbs & Hill et al. 2006 \\
\hline & & & GOF & Premature AER regression & \\
\hline \multirow[t]{5}{*}{ Liver } & Albumin cre & Hepatocytes & LOF & $\begin{array}{l}\text { Smaller liver size, normal recovery of } \\
\text { liver mass after hepatectomy, } \\
\text { impaired ammonia detoxification }\end{array}$ & $\begin{array}{l}\text { Sekine et al. 2006, 2007; Tan } \\
\text { et al. } 2006\end{array}$ \\
\hline & Fabpl cre & Hepatocytes & GOF & No liver carcinogenesis & Harada et al. 2002 \\
\hline & Viral cre & Mosaic in liver and gut & & & \\
\hline & Foxa3 cre & $\begin{array}{l}\text { Foregut and liver } \\
\text { endoderm }\end{array}$ & LOF & $\begin{array}{l}\text { Defects in hepatoblast expansion and } \\
\text { maturation }\end{array}$ & Tan et al. 2008 \\
\hline & $\begin{array}{l}\alpha \text { FP-Albumin } \\
\text { cre }^{\mathrm{k}}\end{array}$ & Postnatal hepatocytes & LOF & Impaired liver growth & Apte et al. 2006, 2007 \\
\hline \multirow[t]{3}{*}{ Lung } & SP-C cre $^{1}$ & Lung epithelium & LOF & $\begin{array}{l}\text { Inhibition of distal airways, } \\
\text { enlargement of proximal airways }\end{array}$ & \multirow{3}{*}{$\begin{array}{l}\text { Mucenski et al. 2003, 2005; } \\
\text { Shu et al. 2005; De Langhe } \\
\text { et al. 2008; Yin et al. 2008; } \\
\text { Zhang et al. } 2008\end{array}$} \\
\hline & CCSP cre $^{\mathrm{m}}$ & & GOF & $\begin{array}{l}\text { Enlargement of distal airways, } \\
\text { inhibition of proximal airways, } \\
\text { increased amount of } \\
\text { bronchioalveolar stem cells }\end{array}$ & \\
\hline & Dermol cre & Lung mesenchyme & LOF & $\begin{array}{l}\text { Loss of lung muscle progenitors, } \\
\text { impaired lung growth }\end{array}$ & \\
\hline $\begin{array}{l}\text { Mammary } \\
\text { gland }\end{array}$ & $\begin{array}{l}\text { WAP cre } \\
\text { MMTV cre }\end{array}$ & Mammary epithelium & GOF & $\begin{array}{l}\text { Mammary hyperplasia, precocious } \\
\text { differentiation }\end{array}$ & $\begin{array}{l}\text { Miyoshi et al. 2002; Renou et } \\
\text { al. } 2003\end{array}$ \\
\hline \multirow[t]{2}{*}{$\begin{array}{r}\text { Neural } \\
\text { crest }\end{array}$} & Wntl cre & $\begin{array}{l}\text { Neural crest } \\
\text { progenitors }\end{array}$ & LOF & $\begin{array}{l}\text { Loss of mid-brain and part of } \\
\text { hindbrain, loss of cranial bone } \\
\text { and cartilage, lack of sensory } \\
\text { neurons and melanocytes, loss of } \\
\text { Schwann cells }\end{array}$ & \multirow[t]{2}{*}{$\begin{array}{l}\text { Brault et al. 2001; Hari et al. } \\
\text { 2002; Lee et al. } 2004\end{array}$} \\
\hline & & & GOF & Expansion of sensory lineage & \\
\hline
\end{tabular}


Table 1. (continued)

\begin{tabular}{|c|c|c|c|c|c|}
\hline Organ $^{a}$ & Cre line & Cre expression & $\beta$-catenin & Phenotype & References \\
\hline \multirow[t]{4}{*}{ Pancreas } & \multirow[t]{2}{*}{ Pdxl cre } & \multirow[t]{2}{*}{ Pancreas progenitors } & LOF & $\begin{array}{l}\text { Reduction of exocrine and } \\
\text { endocrine compartments }\end{array}$ & \multirow{4}{*}{$\begin{array}{l}\text { Dessimoz et al. 2005; } \\
\text { Murtaugh et al. 2005; } \\
\text { Heiser et al. 2006; } \\
\text { Rulifson et al. 2007; } \\
\text { Wells et al. } 2007\end{array}$} \\
\hline & & & GOF & Increased exocrine compartment & \\
\hline & Elastase cre & Exocrine pancreas & LOF & Reduced exocrine compartment & \\
\hline & RIP cre & Pancreatic $\beta$ cells & GOF & Increased $\beta$-cell proliferation & \\
\hline \multirow[t]{2}{*}{ Pituitary } & Pitx1 cre & $\begin{array}{l}\text { Radthke's pouch } \\
\text { progenitors }\end{array}$ & $\begin{array}{l}\text { LOF } \\
\text { GOF }\end{array}$ & $\begin{array}{l}\text { Loss of Pit1-dependent cell types } \\
\text { Absence of the pituitary }\end{array}$ & \multirow[t]{2}{*}{ Olson et al. 2006} \\
\hline & Pit1 cre & $\begin{array}{l}\text { Sublineages of the } \\
\text { pituitary }\end{array}$ & LOF & No effect on cell differentiation & \\
\hline \multirow[t]{5}{*}{$\begin{array}{l}\text { Reproductive } \\
\text { system }\end{array}$} & 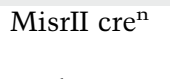 & $\begin{array}{l}\text { Müllerian duct } \\
\text { mesenchyme }\end{array}$ & LOF & $\begin{array}{l}\text { Switch from myogenesis to } \\
\text { adipogenesis }\end{array}$ & \multirow[t]{2}{*}{$\begin{array}{l}\text { Arango et al. 2005; } \\
\text { Deutscher et al. } 2007\end{array}$} \\
\hline & Amhr2 cre $^{\mathrm{o}}$ & & LOF & $\begin{array}{l}\text { Uterine horn hypotrophy and loss } \\
\text { of oviduct coiling }\end{array}$ & \\
\hline & \multirow[t]{2}{*}{$\mathrm{AMH} \mathrm{cre}^{\mathrm{p}}$} & \multirow[t]{2}{*}{ Sertoli cells } & LOF & $\begin{array}{l}\text { No effect on testis/Sertoli cell } \\
\text { development }\end{array}$ & \multirow[t]{2}{*}{ Chang et al. 2008} \\
\hline & & & GOF & $\begin{array}{l}\text { Testicular cord disruption and } \\
\text { germ cell loss }\end{array}$ & \\
\hline & MMTV cre & Prostate epithelium & GOF & $\begin{array}{l}\text { Hyperproliferation and metasplasia } \\
\text { of prostate epithelium }\end{array}$ & Bierie et al. 2003 \\
\hline \multirow[t]{6}{*}{ Skin } & K14 cre & Epidermis and teeth & LOF & Loss of hair follicles & \multirow{4}{*}{$\begin{array}{l}\text { Gat et al. 1999; Huelsken } \\
\text { et al. 2001; Ito et al. } \\
\text { 2007; Malanchi et al. } \\
2008\end{array}$} \\
\hline & & & GOF & $\begin{array}{l}\text { De novo hair generation, tumor } \\
\text { formation after wounding }\end{array}$ & \\
\hline & $\mathrm{K} 14^{\mathrm{ERT}} \mathrm{cre}^{\mathrm{q}}$ & & LOF & $\begin{array}{l}\text { Tumor regression, loss of cancer } \\
\text { stem cells, prevention of de novo } \\
\text { hair follicle generation after } \\
\text { wounding }\end{array}$ & \\
\hline & \multirow[t]{2}{*}{$\begin{array}{l}\text { Engrailed } 1 \\
\text { cre }\end{array}$} & \multirow[t]{2}{*}{$\begin{array}{l}\text { Central } \\
\text { dermomyotome }\end{array}$} & LOF & $\begin{array}{l}\text { Loss of dorsal and ventral dermis } \\
\text { and hair placodes }\end{array}$ & \\
\hline & & & GOF & $\begin{array}{l}\text { Expansion of dorsal dermis, ectopic } \\
\text { dermis }\end{array}$ & \multirow[t]{2}{*}{$\begin{array}{l}\text { Atit et al. 2006; Ohtola } \\
\text { et al. } 2008\end{array}$} \\
\hline & HoxB6 cre & $\begin{array}{l}\text { Lateral plate } \\
\text { mesoderm }\end{array}$ & LOF & $\begin{array}{l}\text { Lack of the ventral dermis and } \\
\text { ventral body wall }\end{array}$ & \\
\hline \multirow[t]{2}{*}{ Somites } & $\begin{array}{l}\text { Brachyury } \\
\text { cre }\end{array}$ & Mesoderm progenitors & LOF & $\begin{array}{l}\text { Loss of posterior paraxial } \\
\text { mesoderm, abnormal } \\
\text { segmentation }\end{array}$ & \multirow[t]{2}{*}{$\begin{array}{l}\text { Aulehla et al 2008; Dunty } \\
\text { et al } 2008\end{array}$} \\
\hline & & & GOF & $\begin{array}{l}\text { Expanded posterior paraxial } \\
\text { mesoderm, abnormal } \\
\text { segmentation }\end{array}$ & \\
\hline $\begin{array}{l}\text { Stomach/ } \\
\text { esophagus }\end{array}$ & Shh cre & Stomach endoderm & GOF & $\begin{array}{l}\text { Reduced stomach size, inverted } \\
\text { positioning of cell types of the } \\
\text { esophagus, posteriorization of the } \\
\text { gut tube }\end{array}$ & Kim et al. 2005 \\
\hline Taste buds & K14 cre & Sensory epithelium & $\begin{array}{l}\text { LOF } \\
\text { GOF }\end{array}$ & $\begin{array}{l}\text { Loss of fungiform taste placodes } \\
\text { Ectopic fungiform placodes }\end{array}$ & Liu et al. 2007 \\
\hline Tooth & K14 cre & Tooth progenitors & GOF & Supernumerary tooth generation & Järvinen et al. 2006 \\
\hline
\end{tabular}

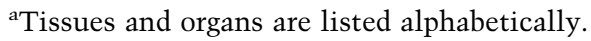

${ }^{\mathrm{b}}$ Osterix $1 \mathrm{cre}$.

${ }^{\mathrm{c}}$ Proopiomelanocortin cre.

${ }^{\mathrm{d}}$ Human skeletal actin cre.

${ }^{\text {e}} \mathrm{Cre}$ is expressed in lens, and partially in retina.

${ }^{\mathrm{f}}$ Mesoderm posterior cre.

${ }^{g}$ Smooth muscle $22 \alpha$ cre.

${ }^{\mathrm{h}}$ Myocyte enhancer factor 2C anterior heart field enhancer and promoter (AHF) cre.

${ }^{i}$ Inducible $\alpha$-myosin light chain cre.

'Tamoxifen-inducible Villin cre.

${ }^{\mathrm{k}} \alpha$-fetoprotein enhancer-albumin cre.

${ }^{1}$ Inducible surfactant protein $\mathrm{C}$ cre.

${ }^{m}$ Clara cell-specific protein cre.

${ }^{\mathrm{n}}$ Müllerian inhibiting substance type II receptor cre.

${ }^{\circ}$ Anti-Müllerian hormone receptor 2 cre.

${ }^{\mathrm{p} A n t i-M u ̈ l l e r i a n ~ h o r m o n e ~ c r e . ~}$

'Tamoxifen-inducible K14 cre. 


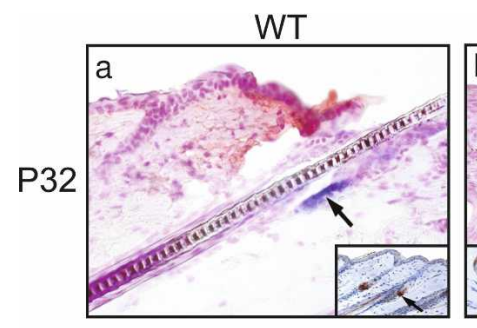

WT
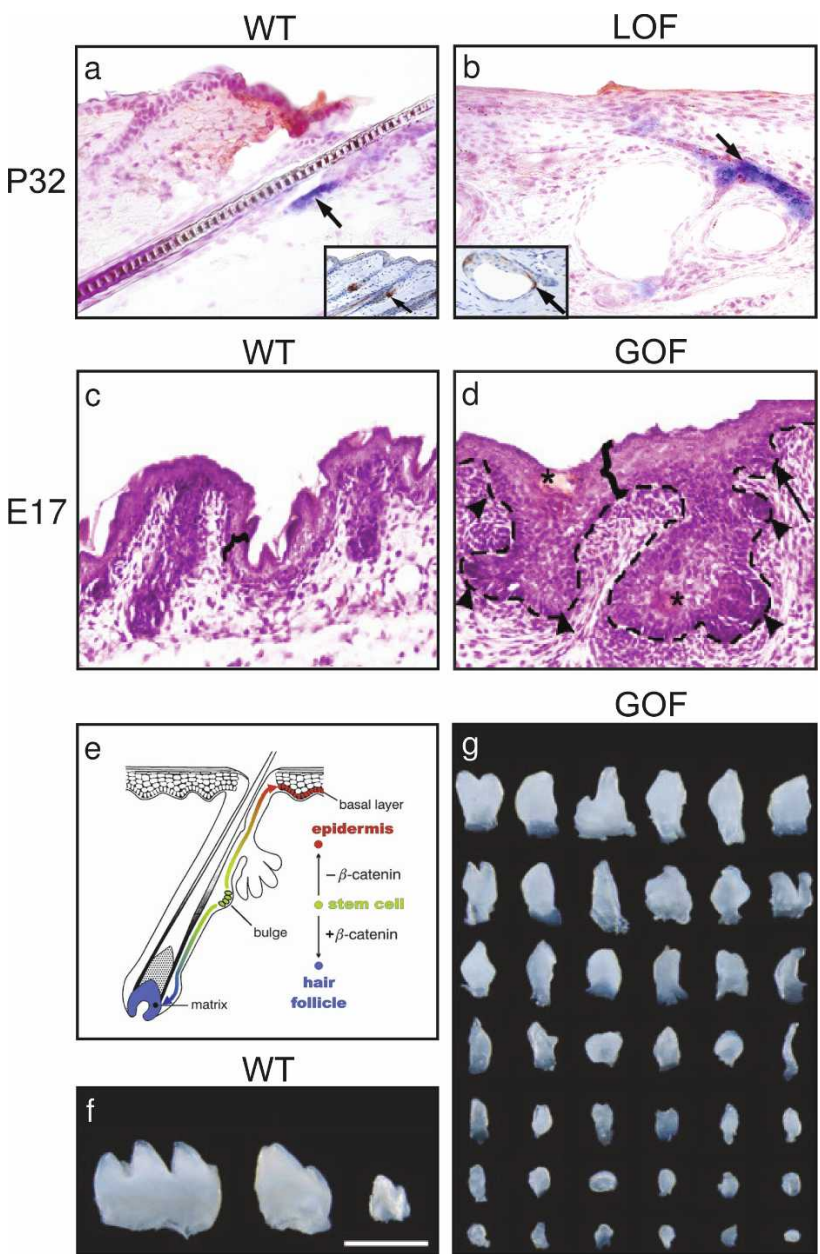

GOF

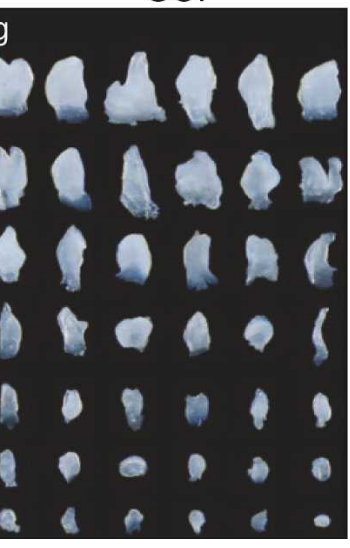

Figure 3. Wnt $/ \beta$-catenin signaling in skin and teeth. $(a, b)$ Conditional loss-of-function mutations of $\beta$-catenin in skin prevent hair follicle generation and result in formation of cysts at P32. Stem cells are localized to the specific areas close to the cysts in $\beta$-catenin loss-of-function mutants, as shown by in situ hybridization for the stem cell marker Keratin 15 (arrows) and immunohistochemistry for $\beta 1$-integrin (insets, arrows). $(c, d)$ Conditional gain-of-function mutations of $\beta$-catenin in skin result in disturbed hair follicle morphogenesis at E17, which is accompanied by epidermal thickening (brackets) and the formation of additional hair placodes ( $d$, arrows and arrowheads), as well as in keratin deposits $(d$, asterisks). (e) Scheme of the role of $\beta$-catenin in fate decisions of the bulge stem cells toward follicular or epidermal lineages. $(f, g)$ Conditional gain-of-function mutations of $\beta$-catenin in tooth epithelium lead to generation of supernumerary teeth of various developmental stages and sizes from one mutant molar tooth bud. $a, b$, and $e$ are reprinted with permission from Huelsken et al. (2001) with permission from Elsevier. $c$ and $d$ are reprinted by permission of the Company of Biologists from Närhi et al. (2008). $f$ and $g$ are reprinted with permission from Järvinen et al. (2006); (c) 2006 National Academy of Sciences, U.S.A.

at later stages for patterning of the molar cusp and for establishment of molar polarity (Liu et al. 2008). Wnt signaling is also essential in tooth renewal (Järvinen et al. 2006): Conditional gain-of-function mutations of $\beta$ catenin in tooth epithelium resulted in continuous for- mation of teeth, and in generation of supernumerary teeth ( $>40$ teeth from one tooth germ) (Fig. $3 f, g)$. It remains to be determined whether a stem cell population exists in the tooth germs of the dental epithelium and if so, what role Wnt signaling plays in such cells. Canonical Wnt signaling is not only required in the epithelium, but also in the mesenchyme of skin and its appendages, as demonstrated by the analysis of Lef1 mutant and Dkk1-transgenic mice (van Genderen et al. 1994; Andl et al. 2002; Sasaki et al. 2005; Liu et al. 2008). This fits given the fact that epithelial-mesenchymal interactions are known to govern hair and tooth development.

Just as proper canonical Wnt signaling guides healthy development in these tissues, defects play a role in tumors, as revealed by the analysis of loss- and gain-of function mutations in $\beta$-catenin. Cancer stem cells and normal stem cells share many characteristics, like the capacity for self-renewal and differentiation and their dependence on a particular micro-environment, the (cancer) stem cell niche (for review, see Passegue and Weissman 2005; Wilson and Trumpp 2006; Fodde and Brabletz 2007; Sneddon and Werb 2007). Malanchi et al. (2008) have now identified a population of cancer stem cells in mouse epidermal tumors-i.e., early squamous cell carcinomas-that are dependent on $\beta$-catenin and that are phenotypically and functionally similar to normal bulge skin stem cells. These cancer stem cells can be isolated by cell sorting based on the presence of the stem cell marker CD34 and absence of other markers. In normal mouse skin, $\mathrm{CD} 34^{+}$bulge stem cells account for $\sim 1.8 \%$ of keratinocytes. However, cutaneous tumors, induced by chemical (DMBA/TPA) carcinogenesis or by expression of the Ras oncogene, contain a ninefold increase of the $\mathrm{CD} 34^{+}$cell population. The tumorigenic capacity of the CD $34^{+}$cells was $>100$-fold greater than that of unsorted cells. Secondary tumors that formed after transplantation resembled the parental tumors. For example, they also contained a small population of $\mathrm{CD} 34^{+}$stem cells. Remarkably, the deletion of $\beta$-catenin in DMBA/ TPA or Ras-induced tumors using an inducible system that allows conditional mutagenesis after the addition of tamoxifen (K14-cre ${ }^{\mathrm{ERT}} ; \beta$-catenin ${ }^{\mathrm{Wbm} / \text { flox }}$ ) resulted in complete tumor regression (Malanchi et al. 2008).

Thus, canonical Wnt signals are required in normal skin to instruct bulge stem cells toward the hair cell fate, whereas in epidermal tumors, they control the maintenance of skin cancer stem cells. It may be possible to exploit this differential response of normal and cancer stem cells in therapies. Overall, the analysis of conditional loss- and gain-of-function mutations of $\beta$-catenin was fundamental for these discoveries.

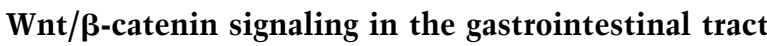 and pancreas}

Wnt signaling plays a crucial role during development of the gastrointestinal tract, in particular, in endoderm specification and gut tube patterning, as well as in intestinal stem cell maintenance (Lickert et al. 2002; Gregorieff et al. 2004). During development, the gastrointesti- 
nal tract forms from the embryonic gut tube. This structure, which is of endodermal origin, undergoes a series of morphogenic changes and patterning events along its A-P and dorsal-ventral (D-V) axes that give rise to major organs such as the esophagus, stomach, and intestine (small intestine, colon), as well as to associated organs including the liver, pancreas, and thyroid (Wells and Melton 1999; Gregorieff and Clevers 2005). The absorptive epithelium of the small intestine is ordered into villi and crypts of Lieberkuehn; in contrast, colon epithelium consists of crypts only. Intestinal crypts are stem cell niches that ensure the self-renewing capacity of the intestine through maintenance of intestinal stem cells and proliferation of transit amplifying cells, which give rise to all differentiated cell types, that is, enterocytes, enteroendocrine and goblet cells of the villi, and to the Paneth cells, which reside at the bottom of the crypts. Activated Wnt signaling is required in the posterior part of the gut tube for intestinal lineage specification, whereas in the anterior part, stomach and esophagus formation require Wnt repression (Gregorieff et al. 2004; Okubo and Hogan 2004). In the adult intestine, canonical Wnt activity is restricted to the proliferative compartment of crypts only. Remarkably, the crypt progenitor compartment of the small intestine was completely lost in Tcf4 ${ }^{-/-}$mice, whereas the differentiated villus epithelium was initially unaffected (Korinek et al. 1998). This demonstrated that downstream from canonical Wnt signaling, the Tcf4-driven genetic program is essential to maintain the crypt stem cells of the small intestine.

As in the skin, defects in Wnt signaling in the intestine can lead to cancer. The first gene of the Wnt pathway to be implicated in human cancer was APC (Adenomatous Polyposis coli), a gene that is silenced in $85 \%$ of human colon cancers (for review, see Kinzler and Vogelstein 1996; Bienz and Clevers 2000; Polakis 2000; Clevers 2006). Consequently, numerous mouse models have been generated that resembled human colon cancer, such as APC ${ }^{\mathrm{Min}}$ and other APC mutants, as well as a mouse that overexpresses $\mathrm{N}$-terminally truncated $\beta$ catenin (Moser et al. 1990; Oshima et al. 1995; Wong et al. 1996; Smits et al. 1999). The first conditional gain-offunction mutation of $\beta$-catenin related to the formation of the intestinal epithelium was introduced by Taketo and colleagues (Harada et al. 1999), using $\beta$-cate$\operatorname{nin}^{\mathrm{Mmt} / \text { flox }}$ and $\mathrm{K} 19$ cre (Table 1). Numerous polyps in the small intestine (up to 3000 per mouse) were found in all mice at a young age. In contrast to the well-separated polyps in the Apc ${ }^{\text {min }}$ model, polyps of the $\beta$-catenin mutants were mainly formed in contiguous sheet-like structures, and nascent microadenomas were found in the colon mucosa. Conditional gain-of-function mutations of $\beta$-catenin were also introduced postnatally in the intestinal villae, using a cre driven by the fatty acid binding protein gene promoter (Fabl cre). The mutant mice developed well-separated polyps at the crypt intervillus region (200-700 per mouse) (Harada et al. 1999). In both models, polyps were composed uniquely of enterocytes. Since the gain-of-function $\beta$-catenin mutations closely resembled $\mathrm{APC}^{\mathrm{min}}$, it is likely that APC acts through $\beta$-catenin in adenoma formation (for review, see Clarke 2006). An elegant recent study genetically demonstrated that $\mathrm{c}-\mathrm{myc}$ is an essential downstream target of APC/ $\beta$ catenin in the intestine. The conditional ablation of $\mathrm{c}$ myc using an inducible Cyp450 promoter-driven cre normalized the tissue; i.e., restored proper proliferation, induced differentiation, and increased crypt size, which were perturbed following conditional loss of Apc (Sansom et al. 2007). Conditional loss-of-function mutations of $\beta$-catenin were also introduced in the intestinal epithelium using two cre lines, inducible Cyp450 and villin cre (Table 1; Ireland et al. 2004; Fevr et al. 2007). Inactivation of $\beta$-catenin resulted in rapid loss of crypt structures, and the increased differentiation of stem cells and transient amplifying cells into enterocytes, similar to the Tcf4 $4^{--}$phenotype (Korinek et al. 1998). Conditional gain-of-function mutations of $\beta$-catenin were also introduced in the stomach and esophagus epithelium, using Sonic Hedgehog cre (Table 1; Kim et al. 2005). Mutant embryos showed reduced stomach size and highly disorganized glandular morphology. The esophagus displayed inverted positioning of squamous and cuboidal epithelial cell types along the $\mathrm{D}-\mathrm{V}$ axis. The esophagus epithelium showed abnormal mucin secretion, which is normally produced by the stomach, indicating posteriorization of the gut tube (Kim et al. 2005, 2007). These data are consistent with the general role of Wnt signaling in the establishment of A-P and D-V polarity of the gut tube.

In summarizing the data on conditional mutagenesis of $\beta$-catenin in the intestine, we should mention that many important functions of canonical Wnt signals were identified earlier, in the 1990s; i.e., before conditional mutagenesis of $\beta$-catenin was first used in 1999. For instance, much information on the role of Wnt signaling in the intestine was generated by the analysis of APC functions in tumor formation, or the biochemical characterization of the $\beta$-catenin/APC and $\beta$-catenin/Tcf interaction and their role in Wnt signaling (Bodmer et al. 1987; Leppert et al. 1987; Moser et al. 1990; Su et al. 1992; Munemitsu et al. 1995; Behrens et al. 1996; for review, see Kinzler and Vogelstein 1996; Bienz and Clevers 2000; Polakis 2000; Clevers 2006). The generation of the first $\beta$-catenin gain-of-function mutation $\left(\beta\right.$-catenin ${ }^{\mathrm{Mmt} / \mathrm{flox}}$, K19 cre) in the intestine was, however, revealing (Harada et al. 1999), since it demonstrated consistency with the previously shown data and validated the genetic approach of the conditional gain-of-function mutations of $\beta$-catenin in mice.

In order to study the role of canonical Wnt signaling in pancreas development, several laboratories produced loss- and gain-of-function mutations of $\beta$-catenin in the endoderm that is committed to form pancreas (Table 1 ; Dessimoz et al. 2005; Murtaugh et al. 2005; Heiser et al. 2006; Rulifson et al. 2007; Wells et al. 2007). Development of the pancreas starts with two epithelial invaginations of the posterior foregut endoderm, which expand and invade the surrounding mesenchyme. There they branch and differentiate to form two lobes of the mature pancreas (for review, see Wells and Melton 1999). Gut rotation brings these dorsal and ventral lobes to a close 
proximity, where they undergo partial fusion. The mature pancreas consists of two functionally different compartments: endocrine and exocrine. The exocrine compartment occupies most of the pancreatic mass and consists of acinar cells, which produce digestive enzymes. These enzymes are directed to the intestine through a branched network of ducts. The endocrine compartment is localized to the islets of Langerhans and is comprised of several hormone-producing cell types, the most prominent being $\beta$ cells, producing insulin; $\alpha$ cells, producing glucagon; $\delta$ cells, producing somatostatin; PP cells, producing pancreatic polypeptide; and $\varepsilon$ cells, producing Ghrelin (for review, see Wells and Melton 1999).

$\beta$-Catenin gain-of-function mutations in mice demonstrated that canonical Wnt signaling plays a crucial role in the regulation of pancreatic growth in temporal and spatial manners. By characterizing the two available Pdxl cre lines, Heiser et al. (2006) showed that early $\beta$-catenin gain-of-function mutations, introduced using an early Pdx1 cre (expression starting E11.5), resulted in pancreatic agenesis and reduction in both endocrine and exocrine compartments (Table 1). In contrast, when $\beta$ catenin gain-of-function mutations were introduced using the late Pdx1 cre (expression starting E12.5), the pancreas was enlarged by $>50 \%$ due to an increase in the proliferation of the exocrine compartment, whereas the endocrine compartment was not affected. Similar results were observed using an inducible Pdxl creER line (Heiser et al. 2006). A role for another member of the Wnt signaling cascade, GSK3, downstream from Wnt and insulin signaling has been shown (McManus et al. 2005). These results indicate that canonical Wnt signaling plays various roles at different stages of pancreas development. In addition, it has also been shown that $\beta$-catenin acts upstream of Fgf10 and Hedgehog signaling in mediating pancreatic hypoplasia and cyst formation (Heiser et al. 2006). The characterization of the two Pdx1 cre transgenic models might, in part, explain the previously observed differences in pancreatic phenotypes following $\beta$-catenin loss-of-function mutations. $\beta$-Catenin loss-of-function mutantions using early $\mathrm{Pdx} 1$ cre demonstrated pancreatic hypoplasia associated with a dramatic reduction of the exocrine tissue (Murtaugh et al. 2005; Wells et al. 2007). Expression of Ptfla, an essential gene in acinar development, was lost in the $\beta$-catenin loss-of-function mutant mice. Similar results were obtained when loss-of-function mutations of $\beta$-catenin were introduced specifically into the acinar cell lineage, using an inducible Elastase cre ${ }^{\mathrm{ERT}}$ (Murtaugh et al. 2005). Conversely, Dessimoz et al. (2005) demonstrated that loss-of-functions mutations of $\beta$-catenin, using late Pdxl cre affected the endocrine pancreas. The respective total numbers of insulin and glucagon-expressing cells dropped to about a half of their normal levels (Dessimoz et al. 2005). Gain-of function mutations of $\beta$-catenin introduced specifically in the $\beta$-cell lineage, using rat insulin II promoter-driven cre (RIP cre), demonstrated a threefold increase in the proliferation of $\beta$ cells and a 2.5 -fold increase in $\beta$-cell mass (Table 1 ; Rulifson et al. 2007). Serum insulin levels in these mice were signifi- cantly increased, and blood glucose concentration was reduced. The increase in $\beta$-cell proliferation was associated with an increase in expression of Wnt signaling targets cyclinD2 and Pitx2. These results suggest that Wnt signaling is required for cyclinD2- and Pitx2-mediated $\beta$-cell proliferation (Rulifson et al. 2007). Overall, these results demonstrated that canonical Wnt signaling plays a role at different stages of pancreas development. In early stages, it affects overall pancreas development, whereas in late stages, it is required for exocrine and endocrine cell proliferation. In view of a recent discovery that pancreas size is limited by the size of the progenitor cell pool that is specified during early pancreatic development (Stanger et al. 2007), it would be important to investigate what impact Wnt signaling has on this progenitor pool.

\section{Wnt/ $\beta$-catenin signaling in the CNS}

Various signaling systems play crucial roles in the development of different cell types and tissues during the formation of the CNS, and here, too, Wnt signaling has been found to be essential (Table 1). Neural progenitor cells are located in defined areas of the CNS; the precursors proliferate to renew the progenitor pool, while giving rise to postmitotic neuronal cells that move out of the progenitor areas (Temple 2001; Zhao et al. 2008). The progenitors receive information that allocates positional identity in the early stages of nervous system development. This positional identity will eventually determine whether a progenitor will become a glial or a neuronal cell and if the latter, which type it becomes. Positional identity is transmitted via signaling systems, which work along the A-P and D-V axes of the neural tube. These signaling systems also control progenitor proliferation, the size of the tissue domains, and the number of neurons generated by the precursors. Wnt signaling plays important roles at different stages of this developmental program, as demonstrated by the complex expression patterns of Wnts and Wnt receptors, as well as by knockdown and overexpression studies in Xenopus, zebrafish, chick, and mice (for instance, see Capecchi 1990; McMahon and Bradley 1990; Muroyama et al. 2002; Bonner et al. 2008). Wnt signals can direct cell fates in a concentration-dependent manner, thus acting as morphogens (for review, see Yamaguchi 2001). Noteworthy are early studies that demonstrated the expression of Wnts in various patterning centers of the nervous system, for instance, in the mid-hindbrain organizer or in the telencephalon. These signals are now known to control proliferation and cell fate specification of neuronal progenitors in these regions. The functions have usually been recognized and analyzed in mutants that lack genes encoding Wnt ligands or receptors (McMahon et al. 1992; Sur and Rubenstein 2005).

Loss- and gain-of-function mutations of $\beta$-catenin have been used to systematically investigate the role of Wnt signaling in the spinal cord, using Brain 4 (Brn4) cre (Table 1; Zechner et al. 2003, 2007). The most pronounced effect of these mutations was changes in the 
size of the spinal cord. It is significantly smaller in lossof-function mutants (Fig. 4a,b) and significantly enlarged in the $\beta$-catenin gain-of-function mutants (Fig. 4a,c). Similar effects were seen in the ventricular zones occupied by progenitor cells, which were reduced in the lossof-function and were enlarged in the gain-of-function mutant mice (Fig. 4a-c, marked green, with anti-Nestin antibodies). Predictably, lower numbers of progenitors were accompanied by higher numbers of differentiated neurons, and an increase in progenitors was correlated with lower numbers of differentiated cells (Fig. 4a-c, red, marked by anti Tubulin J1 antibodies). The change in size of the spinal cord is the result of a shift in the balance between precursor renewal and differentiation: Loss of $\beta$-catenin increases the probability that a precursor will undergo neuronal differentiation instead of self-renewal, whereas $\beta$-catenin gain-of-function mutation has the converse effect (Zechner et al. 2003). These data are in line with earlier reports that relied on the overexpression of activated $\beta$-catenin in the chick spinal cord by electroporation, or transgenic expression of Nestin$\Delta$ N90 $\beta$-catenin in mice: Overexpression resulted in in-
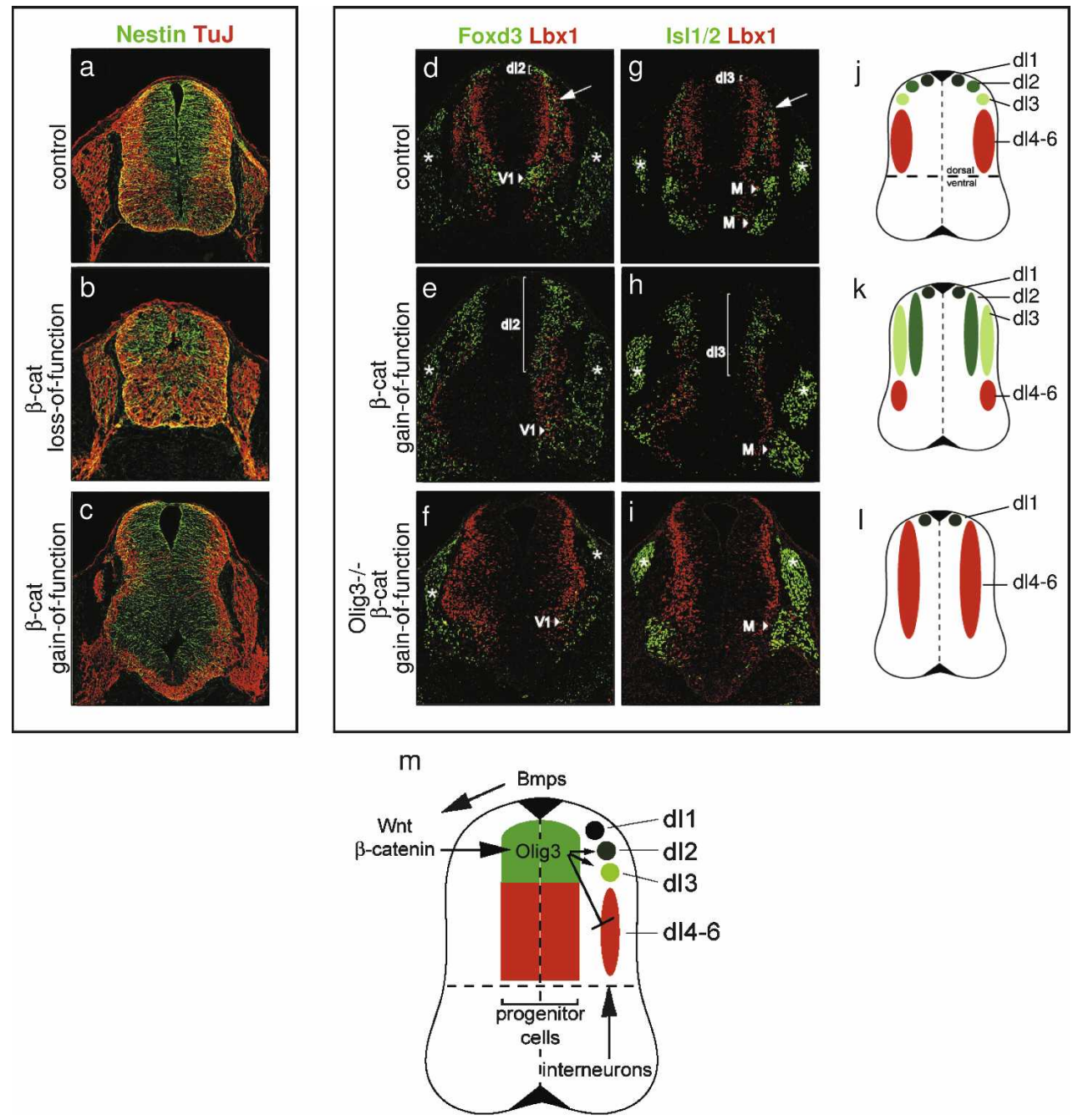

Figure 4. Wnt $/ \beta$-catenin signaling in the spinal cord. $(a-c)$ Changes in the size of the neural progenitor pool in $\beta$-catenin mutants. At E11.5, sizes of spinal cords and the neural progenitor pool are reduced in $\beta$-catenin loss-of-function mutants $(a, b)$ and increased in $\beta$-catenin gain-of-function mutants, as shown by Nestin-specific antibodies in green $(a, c)$. Accordingly, the mantle zones are increased in the loss-of-function mutants $(a, b)$ and decreased in gain-of-function mutants $(a, c)$, as shown by Tubulin J1-specific antibodies in red. $(d-m)$ Changes in neuronal specification in $\beta$-catenin mutants. Differentiated neurons are shown by antibody staining against Foxd3, dI2 (darker green), Isl1/2, dI3 (light green), and Lbx1, dI4-6 (red). Arrowheads label motor neurons (M) and V1 interneurons (V1) in the ventral spinal cord, and asterisks label the dorsal root ganglia. Progenitor domains that generate dI2 and dI 3 neurons are expanded in $\beta$-catenin gain-of-function mutants (cf. $d, g, j$ and $e, h, k$, labeled with vertical brackets). In compound mutants that carry a gain-offunction mutation of $\beta$-catenin and loss-of-function mutations of Olig3, only Lbx $1+$ but not Foxd3+ and Isl1/2+ neurons are generated in the dorsal spinal cord $(f, i, l)$, indicating requirement of Olig3 expression for dI2 and dI3 neuron generation. (m) In the neuronal progenitor cells, Wnt $/ \beta$-catenin acts downstream from Bmp signaling to promote specification of dI $2 / 3$ neuronal lineages and restrict expansion of dI4-6 lineages via the patterning gene Olig3. Reprinted with permission from Zechner et al. $(2003$, 2007) with permission from Elsevier. 
creased precursor proliferation and a decrease in the neuronal precursor pool, whereas loss-of-function had the opposite effect (Chenn and Walsh 2002; Megason and McMahon 2002).

In parallel, Wnt $/ \beta$-catenin signals pattern the dorsal spinal cord. Six distinct progenitor domains can be distinguished in the dorsal spinal cord based on the expression of different combinations of basic helix-loop-helix (bHLH) transcription factors, like Olig3 (Müller et al. 2005). From these progenitor domains, six types of postmitotic neurons, dI1-dI6, distinguishable by the expression of homeobox transcription factors like Foxd3 (expressed in dI2, Isl1/2 in dI3, and Lbx1 in dI4-6), emerge in the lateral mantle zone. In $\beta$-catenin gain-of-function mutant mice, the expression of the patterning gene Olig3 was massively expanded in dorsal precursors, while in the $\beta$-catenin loss-of-function mutant mice, the Olig 3 expression domain was extinguished (Zechner et al. 2007). These changes in the progenitor zone were accompanied by changes in specification of neurons: Supernumerary and ectopic Foxd $3^{+}(\mathrm{dI} 2)$ and Isl1/2+ (dI 3$)$ neurons were generated in the gain-of-function mutant (Fig. $4 e, h, k$; Zechner et al. 2007). In line with this finding, earlier ablation of Wnt1/3a in mice had resulted in a reduction of the numbers of $\mathrm{dI} 2$ and $\mathrm{dI} 3$ neurons (Muroyama et al. 2002). Previous genetic experiments had shown that Olig3 in the progenitor domain is essential for specification of dI2 and dI3 neurons (Müller et al. 2005). Therefore, we generated compound mutant mice that carry a gain-of-function mutation in $\beta$-catenin and a loss-of-function mutation in Olig3. The proliferative response in the progenitor zone was still observed, while the $\beta$-catenin-dependent specification of supernumerary dI 2 and dI3 neurons was blocked in the compound mutant mice (Fig. 4f,i,l; Zechner et al. 2007). Another finding was that Bmp signals act upstream of Wnt $/ \beta$-catenin signals in the control of Olig3 expression and the specification of dorsal interneurons (Zechner et al. 2007). Other studies in the mouse and chick had suggested that Wnt signaling acts downstream from Bmp signaling in the expansion of progenitor population, rather than in patterning in the dorsal spinal cord (Chesnutt et al. 2004; Ille et al. 2007). Recent data obtained from zebrafish experiments, consistent with findings in the mouse, revealed a dual role of Wnt signaling both in proliferation and in patterning. In the zebrafish, the two activities of the Wnt signaling system are mediated by distinct mechanisms: Proliferation is controlled by a Wnt signal via Tcf3, and patterning of the dorsal spinal cord is controlled by a Wnt signal that is mediated by Tcf7; this is Tcf4 in the mouse (Bonner et al. 2008).

Several lines of evidence indicate that Wnts also take over functions in A-P patterning of the brain and spinal cord. Several canonical and noncanonical Wnt ligands are expressed along the neural A-P axis, where they are thought to have developmental functions (Kimura et al. 2000; Perea-Gomez et al. 2001). The importance of inhibiting the Wnt pathway for brain specification in the anterior neural tube is demonstrated by genetic studies in zebrafish, Xenopus, and mice (Kazanskaya et al. 2000;
Kim et al. 2000; Kiecker and Niehrs 2001; Yamaguchi 2001). In mice, overexpression of Wnt8c resulted in posterior axis duplication and a loss of the anterior neural structures (Popperl et al. 1997). Moreover, loss of Dickkopf1 (Dkk1) expression led to posteriorization of the anterior neuroectoderm and loss of forebrain structure, but did not affect the spinal cord (Kimura et al. 2000; Mukhopadhyay et al. 2001; Perea-Gomez et al. 2001; del Barco Barrantes et al. 2003). Finally, recent studies demonstrated that guidance of commissural axons along the A-P axis of the spinal cord is mediated by Wnts (Lyuksyutova et al. 2003). Future studies in which $\beta$-catenin undergoes conditional loss- and gain-of-function mutations in the early stages of neural tube development could help to understand the role of canonical Wnt signaling in patterning the neural $\mathrm{A}-\mathrm{P}$ axis and separate canonical from noncanonical Wnt signaling in this complex process. Loss-of-function mutations of $\beta$-catenin have also been used to study brain morphogenesis, using Nestin, D6, Emx1, and proopiomelanocortin cre lines (Table 1; Machon et al. 2003; Campos et al. 2004; Gao et al. 2007; Schuller and Rowitch 2007). These studies have demonstrated the important role of $\beta$-catenin-mediated signals in the formation of the cerebral cortex and hippocampus. Moreover, conditional ablation of $\beta$-catenin in postnatal motorneurons using human skeletal actin cre (HSA cre) revealed a role of canonical Wnt signaling in neuro-muscular junction formation (Li et al. 2008). Overall, the studies of loss- and gain-of-function mutations of $\beta$-catenin in the CNS demonstrated that Wnt signals direct differentiation, for instance, determine subtypes of sensory neurons and pattern the spinal cord. In parallel, Wnt signals allow maintenance and expansion of the corresponding progenitor pool.

\section{Wnt/ $\beta$-catenin signaling in the neural crest}

As in the CNS, canonical Wnt signaling is essential in the peripheral nervous system (PNS), where it steps in at an early stage of neural development to help direct cell migrations and patterning in the neural crest. The neural crest begins as a population of multipotent cells that arise at the border between neural and nonneural ectoderm in vertebrates. As the neural tube closes, neural crest cells delaminate dorsally in a rostro-caudal wave and migrate along specific routes throughout the embryo, generating a broad variety of neural and nonneural derivatives. These include peripheral neurons and glia, the craniofacial skeleton, connective tissue and cartilage, pigment cells, and the neuroendocrine epithelium of adrenal glands (for review, see Gammill and BronnerFraser 2003). The differentiation potential of neural crest cells varies along the A-P axis. Cranial neural crest cells give rise to the craniofacial skeleton and cranial ganglia. Vagal and sacral neural crest generate parasympathetic as well as enteric ganglia and contribute to the heart. Trunk neural crest cells give rise to dorsal root ganglia, the sympathetic nervous system, and chromaffin cells of the adrenal gland, as well as melanocytes. A large amount of data obtained in Xenopus, zebrafish, chick, 
and mouse has provided evidence that the Wnt pathway is required for neural crest induction and differentiation (Saint-Jeannet et al. 1997; Chang and Hemmati-Brivanlou 1998; LaBonne and Bronner-Fraser 1998; Tamai et al. 2000; Deardorff et al. 2001; Garcia-Castro et al. 2002; Abu-Elmagd et al. 2006). In the mouse, compound mutant embryos lacking both Wnt1 and Wnt3a show major deficits in neural crest derivatives due to a reduction in neural crest cells (Ikeya et al. 1997). Since not all neural crest derivatives were affected to a similar extent, it was proposed that Wnt1 and Wnt3a might be responsible for the generation of specific subsets of neural crest cells, but not all types (Salinas and Nusse 1992; Parr et al. 1993).

Conditional loss-of-function mutations of the $\beta$-catenin gene using Wntl cre, which introduces cremediated recombination in the dorsal neural tube and all neural crest cells, resulted in dramatic defects in neural crest derivatives (Table 1; Brault et al. 2001). Cranial bones and cartilage of cranial neural crest origin were absent. Craniofacial development requires the communication between cells derived from the neural crest and the cranial paraxial mesoderm, which generates muscle. Conditional $\beta$-catenin/Wnt 1 cre mutant mice permitted an assessment of this interaction, due to the severe changes in cranial neural crest cell differentiation. Neural crest cells are dispensable for cranial muscle progenitor specification but are required for muscle patterning (Rinon et al. 2007). Furthermore, the formation of a further neural crest cell derivative, the heart outflow tract, is also affected in the conditional Wntl cre/ $\beta$-catenin mutant, which is discussed in the next section (Kioussi et al. 2002). In addition, melanocytes did not form, as demonstrated by the absence of the expression of melanocyte-specific genes, such as Mitf, a bHLH transcription factor essential for melanoblast specification (Dorsky et al. 2000; Takeda et al. 2000; Hari et al. 2002; Larue et al. 2003; Saito et al. 2003). Neuronal derivatives of the neural crest also require canonical Wnt signals for differentiation (Hari et al. 2002). Neural crest cells in the lossof-function mutant mice failed to differentiate into the sensory neurons (Hari et al. 2002; Lee et al. 2004). Conditional gain-of-function mutants of $\beta$-catenin, again using Wntl cre, exhibited a converse phenotype (Lee et al. 2004): Neurogenin-2-expressing sensory neurons were found ectopically in the anterior part of the embryo. Thus, activation of canonical Wnt signaling resulted in the expansion of the sensory neuronal lineage at the expense of other neural crest derivatives, indicating that neural crest cells are instructed by Wnt/ $\beta$-catenin signals to assume a sensory neuronal fate (Lee et al. 2004). Moreover, the neural crest of such mutants was unable to generate enteric ganglia and Schwann cells that associate with peripheral axons.

These data on the use of loss- and gain-of-function $\beta$-catenin mutants in mice demonstrate that $\beta$-catenin controls many aspects of neural crest cell development, including survival, progenitor cell expansion, and important lineage decisions. These data, together with experiments in Xenopus, zebrafish, chick, and mouse, suggest that Wnt signaling acts at several stages of neural crest development. At an early stage, Wnt appears to instruct neuronal progenitors that migrate to the dorsal spinal cord to assume a neural crest cell fate (Saint-Jeannet et al. 1997; Lewis et al. 2004), whereas at later stages, Wnt induces expansion and lineage decisions of the neural crest cells. These functions of Wnt $/ \beta$-catenin in neural crest development seem to occur independently of its general role in A-P patterning (for review, see Raible and Ragland 2005).

\section{Wnt/ $\beta$-catenin signaling in cardiogenesis}

Investigations of heart development and homeostasis in mice are prime examples of cases in which many different types of conditional loss- and gain-of-function mutations have been used successfully to expose the roles of Wnt/ $\beta$-catenin signaling (Table 1$)$. The vertebrate heart originates from three separate progenitor cell lineages, the mesoderm-derived first and second heart fields, and the neural crest (see Fig. 5a; Buckingham et al. 2005; Srivastava 2006). Initially, the cells of first and second heart fields (the crescent) migrate toward the midline to form a linear cardiac tube. Cells of the first heart field then contribute to the future left ventricle. Cells of the second heart field proliferate and migrate and direct the rightward looping of the cardiac tube, thereby contributing to the future right ventricle, and inflow and outflow tracts (Buckingham et al. 2005). Neural crest-derived precursors contribute to the complex organization of the heart outflow tract. A role of Wnt/ $\beta$-catenin signaling in heart development has been postulated previously, based on expression profiles of Wnt pathway members, as well as on explant studies in animal models, and in cell culture (for example, see Frasch 1995; Marvin et al. 2001; Schneider and Mercola 2001; Tzahor and Lassar 2001; Nakamura et al. 2003; Foley and Mercola 2005; Eisenberg and Eisenberg 2006).

Conditional ablation of the $\beta$-catenin gene in mesodermal precursors of first and second heart field progenitors during development did not affect the first heart field, but resulted in defects of the second heart field (Klaus et al. 2007). This work used mesoderm posterior 1 (MesP1) promoter-driven cre, the earliest available cre that targets heart lineages (Saga et al. 2000; Klaus et al. 2007). The linear heart tube was correctly formed, while cardiac looping, proper outflow tract, and right ventricle formation were prevented (Fig. 5b,c). The self-renewal of Islet1-expressing progenitor cells, which contribute to second heart field derivatives, was impaired. In contrast, constitutive activation of $\beta$-catenin again using MesP1 cre resulted in disruption of the linear heart tube (Fig. 5, cf. $b$ and d) and in expansion of Islet 1 progenitors. The loss- and gain-of-function mutations of $\beta$-catenin therefore suggest that absence of Wnt $/ \beta$-catenin signaling allows first heart field generation, and that the generation of the second heart field may depend on the correct amount and timing of Wnt/ $\beta$-catenin signaling (Klaus et al. 2007). Consistent with these data, similar phenotypes were produced by removing competence to respond to 


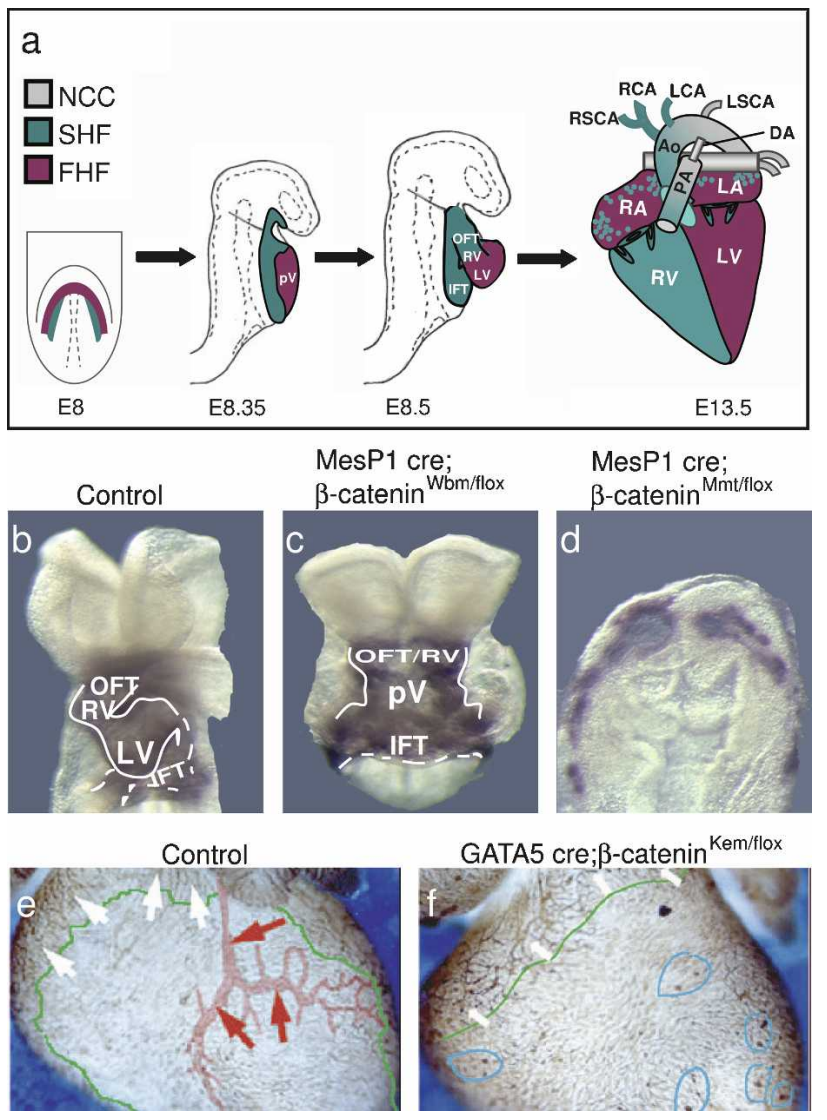

Figure 5. Wnt $/ \beta$-catenin signaling during cardiogenesis. (a) Schemes of mouse embryos at different stages of embryonic development show the location and contribution of first (red) and second (green) heart field cells at cardiac crescent (frontal view), linear heart tube, and looping stages (lateral views). Following rightward looping of the linear heart tube, neural crest cells migrate into the outflow tract and take part in septation and remodeling of the outflow tract, resulting in a multichambered heart at E13.5. (b-d) Conditional ablation and activation of $\beta$-catenin using MesP1-driven cre shows the loss of cardiac looping in MesP1 cre; $\beta$-catenin ${ }^{\text {lox}} /$ lox mice $(b, c)$, and the disruption of cardiac tube formation in MesP1 cre, $\beta$-catenin ${ }^{\text {loxEx } 3 /+}$ mice $(b, d)$ as indicated by whole-mount in situ hybridization for $\mathrm{Nkx2.5}$ and MLC2a at E8.5. $(e, f)$ Conditional ablation of $\beta$-catenin in the proepicardial lineage (Gata5 cre) resulted in the absence of coronary arterial vasculature as indicated by PECAM 1 staining at E18.5 (cf. red arrows in $e$ with $f$ ). (Ao) Aorta; (DA) ductus arteriosus; (FHF) first heart field; (IFT) inflow tract; (LV) left ventricle; (NCC) neural crest; (OFT) outflow tract; $(\mathrm{PA})$ pulmonary artery; $(\mathrm{pV})$ primitive ventricle; $(\mathrm{RV})$ right ventricle; (RA and LA) right and left atrium; (RCA) right carotid artery; (LCA) left carotid artery; (RSCA) right subclavian artery; (LSCA) left subclavian artery; (SHF) second heart field. $b-d$ are reprinted with permission from Klaus et al. (2007); (C) $2007 \mathrm{Na}$ tional Academy of Sciences, U.S.A. $e$ and $f$ are reprinted with permission from Zamora et al. (2007); (C) 2007 National Academy of Sciences, U.S.A.

Wnt signaling at later stages of heart development. This was accomplished through the ablation of $\beta$-catenin in differentiating cardiac progenitors, using Nkx2.5 cre, or in the second heart field using Islet1-cre or Mef2c-AHF cre (Table 1). The phenotypes included defects in second heart field derivatives, partially due to prevention of proper Islet1 progenitor expansion. Conversely, sustained activation of $\beta$-catenin in these cell lineages strongly induced self-renewal of second heart field cells and an expansion of their derivatives (Ai et al. 2007; Kwon et al. 2007; Lin et al. 2007; Qyang et al. 2007). Additionally, gain- and loss-of-function mutations of $\beta$ catenin in myocardial and smooth muscle cells using smooth muscle- $22 \alpha$ cre indicated that Wnt signaling may act upstream of FGF signaling in the regulation of proliferation of Islet1-expressing second heart field cells (Cohen et al. 2007).

Genetic manipulations in the mouse have also shown that Wnt/ $\beta$-catenin signaling contributes to the remodeling of both cardiac blood vessels and the neural crestderived heart outflow tract (Table 1). A loss-of-function mutation of $\beta$-catenin in the heart's neural crest cells, using Wnt 1 cre, affected outflow tract remodeling mediated by transcriptional regulation and activation of Pitx2, which, in turn, was shown to be required for the proliferation of neural crest cells that contribute to the outflow tract (Kioussi et al. 2002; see also previous section). Furthermore, loss-of-function mutations of $\beta$-catenin, using endothelial-specific Tie2 cre, showed that endocardial cells require $\beta$-catenin's transcriptional activity for endothelial-mesenchymal transition during endocardial cushion formation (Liebner et al. 2004). The role of the Wnt pathway in cardiac vessel formation has been also demonstrated by loss-of-function mutations of $\beta$-catenin in epicardium-derived cells, using Gata5 cre. Mutant embryos showed both impaired coronary artery formation and the differentiation of epicardium-derived mesenchymal cells into the smooth muscle lineage (Fig. 5e,f; Zamora et al. 2007). Strikingly, conditional ablation of the $\beta$-catenin gene in the mouse embryonic endoderm, using cytokeratin 19 cre, caused cell fate changes from endoderm to cardiac mesoderm, which resulted in ectopic formation of multiple hearts (Lickert et al. 2002). The investigators conclude that canonical Wnt signaling function in cardiogenesis is, at least in part, due to a cell autonomous role of Wnt signaling in the early endoderm. In the adult heart, loss-of-function mutations of $\beta$-catenin, using two inducible $\alpha$-myosin heavy chain promoter-driven cre lines, resulted in cardiac hypertrophy (Chen et al. 2006; Baurand et al. 2007; Zhou et al. 2007). It has been shown that the pathological, stressinduced growth of cardiomyocytes is dependent on Wnt/ $\beta$-catenin target gene repression rather than on its adhesive function. Similarly, cardiac-specific haploinsufficiency of $\beta$-catenin by heterozygous loss-of-function mutations using noninducible $\alpha$-myosin heavy-chain cre, attenuated cardiac hypertrophy following transverse aortic constriction (Qu et al. 2007).

In conclusion, genetic ablation and activation of the $\beta$-catenin gene in different cardiac cell lineages at different stages of heart development and in the adult (Table 1) provided a complex picture of the temporally and tissuespecific roles of $\mathrm{Wnt} / \beta$-catenin signaling during specification, self-renewal, and differentiation of various popu- 
lations of cardiac progenitor cells. Wnt/ $\beta$-catenin signaling is thus required to maintain and expand cardiac precursor lineages, and it needs to be repressed in order to promote differentiation into cardiomyocytes or smooth muscle cells. How canonical Wnt signaling crosstalks with other developmental signaling pathways and how it controls the transcriptional networks that are essential for heart formation remain to be established.

\section{Wnt/ $\beta$-catenin signaling in sensory placode derivatives}

Recent studies show that Wnt signaling plays crucial developmental roles in the sensory organs. Sensory organs such as the eye, inner ear, and taste buds share a common developmental origin, the interplay of placode and (neuro) ectoderm tissues (Table 1; for review, see Bailey and Streit 2006).

The taste buds of the tongue consist of two compartments, the tongue epithelium in the shape of papillae and the endings of the gustatory nerves, which are of placodal origin, that form clusters of neuronal cells in the center of those papillae. Several types of tongue papillae can be distinguished-fungiform, foliate, and circumvalate-which are organized in a stereotypic pattern on the anterior two-thirds of the dorsal surface of the tongue. Wnt signaling's role in taste bud development has only recently become evident, when loss- and gainof-function mutation of $\beta$-catenin was examined in the tongue epithelium, using K14 cre (Table 1). Moreover, the activation of the Wnt pathway with the GSK3-inhibitor $\mathrm{LiCl}$ in tongue cultures led to an increase in the number of taste placodes (Iwatsuki et al. 2007; Liu et al. 2007). Ablation of the $\beta$-catenin gene in the tongue epithelium, using K14 cre (the same model used to study skin), blocked fungiform taste bud development, as demonstrated by the loss of expression of Shh and Bmp4, indicating that the canonical Wnt pathway is required for the early induction of this developmental process. Overexpression of the Wnt inhibitor Dkk1 under the K5 promoter and ablation of Wnt10b or Lef1 also resulted in severe reduction or complete loss of all fungiform papillae (Iwatsuki et al. 2007; Liu et al. 2007). In contrast, gain-of-function mutations of $\beta$-catenin in the tongue epithelium, again using K14 cre, resulted in the opposite phenotype, a higher placode density and ectopic placode formation (Liu et al. 2007). It has also been shown that the defective taste bud epithelium indirectly affects taste bud innervation. In later stages, Wnt signaling appears to be required for maintaining placode homeostasis. Activation of the Wnt pathway promotes placode formation, whereas in the absence of the Wnt pathway, cells lose placode identity and, instead, adopt an interplacodal fate (Liu et al. 2007). Candidate factors that act downstream from canonical Wnt signaling in placode formation are Sox 2 and Shh. Indeed, it has been shown in Sox2 hypomorphic embryos that decrease of Sox2 leads to a reduction in fungiform placode numbers. In contrast, overexpression of Sox 2 increases fungiform papillae at the expense of filiform papillae development (Okubo et al. 2006).
Recent studies have implicated canonical Wnt signaling in development of the lens and retina. In eye development, mutual inductive signals between optic vesicles and the overlying placodal surface ectoderm promote the thickening of the ectoderm to form the lens placode. Lens placode and optic vesicle further invaginate, resulting in formation of both the lens vesicle and the doublelayered optic cup. The inner layer of the optic cup gives rise to the neural retina, while the outer layer of the optic cup forms the retinal pigmented epithelium (RPE). Various Wnt ligands, Frizzled receptors, and secreted Wnt antagonists, such as Dkk and sFPRs, are expressed in complex patterns during mammalian lens and retina development (Liu et al. 2003; Stump et al. 2003; Ang et al. 2004; Chen et al. 2004). Studies of various Wnt reporter mice have permitted the mapping of canonical Wnt signaling during the eye development (Miller et al. 2006; Kreslova et al. 2007). Conditional loss-of-function mutations of $\beta$-catenin in the lens placode and surrounding head surface ectoderm were introduced by various cre lines, among those the lens cre, LR cre, and Nestin cre (Table 1). In the lens cre, cre expression is driven by the ocular ectoderm-specific enhancer of the Pax6 gene (Ashery-Padan et al. 2000; Smith et al. 2005). LR-cre is expressed in the developing lens and partially, retina. Nestin cre is expressed in the lens epithelium later in development and was used to study lens development at subsequent stages (Kreslova et al. 2007). Mutant $\beta$-catenin embryos showed abnormal eye and lens morphology. Interestingly, loss of $\beta$-catenin in the periocular area resulted in formation of ectopic lentoid bodies that expressed $\beta$-crystallin and Proxl. Introduction of the gain-of-function mutation of $\beta$-catenin, again using lens cre, led to a loss of lens structure and lens-specific marker expression, and to an up-regulation of neuralspecific markers, such as $\beta$-tubulin (Miller et al. 2006). These data suggest that inhibition of canonical Wnt signaling within the lens placode and its activation in the periocular ectoderm are required for the proper lens formation and patterning (Smith et al. 2005). Interestingly, defects in retina development were also observed in the LR cre mutants, since LR cre is mosaically expressed in the retina (Kreslova et al. 2007). A role of canonical Wnt signaling in retinal development, patterning, and regeneration had been previously suggested (Liu et al. 2003; Ouchi et al. 2005; Miller et al. 2006; Osakada et al. 2007).

The inner ear is a composite sensory structure, characteristic for vertebrates, that is responsible for detection of sound, balance, and acceleration. During development, the inner ear originates from a region of the thickened surface ectoderm, the so-called otic placode. Induction of the otic placode is a multistep process that requires signals from the adjacent posterior hindbrain and the cranial paraxial mesoderm (for review, see Streit 2001). A current model proposes two steps in otic placode induction: First, a "preotic placode" separates from a common region of competence for all the craniofacial placodes; during the second step, this preotic placode differentiates into the otic placode and the nonotic sur- 
rounding ectoderm (Ohyama et al. 2006). Genetic studies in Xenopus, zebrafish, chick, and mouse have implicated various signaling pathways to be involved in otic placode induction and patterning (Streit 2001; Mohamed et al. 2004; Ohyama et al. 2006; for review, see Ohyama et al. 2007). To elucidate the role of Wnt signaling during otic placode formation, Ohyama et al. (2006) induced lossand gain-of-function mutations of $\beta$-catenin with Pax2 cre (Table 1). The otic vesicles of loss-of-function embryos showed a severely reduced size, accompanied by increased size of the surrounding cranial ectoderm. Reduced proliferation, increased apoptosis, and a disruption of cell-cell adhesion was detected at the late, but not at the early stages of otic development. In the mutant embryos, expansion of the ectoderm occurred at the expense of the otic placode tissue. An opposite phenotype was observed in $\beta$-catenin gain-of-function mutations: $\mathrm{Mu}$ tant embryos showed an expansion of the otic placode, overexpression of otic markers in ectopic locations, and a reduction of nonplacodal ectoderm. The expansion of the otic placode, which expressed markers Dlx5, Gbx2, and Msx1, was due to a higher proliferation rate (Ohyama et al. 2006). These results suggest that canonical Wnt signaling plays a crucial role in mediating decisions of the Pax2-expressing preotic placode between placodal and epidermal fates. So cells within the preotic field, which receive a high Wnt signal, differentiate into otic placode, whereas cells that receive no or little Wnt signal differentiate into epidermis. During later stages of otic development, canonical Wnt signaling plays a role in D-V patterning of the otocyst (Ohyama et al. 2006). $\beta$-Catenin gain-of-function mutants showed a large expansion of dorsal markers at the expense of the ventral markers. These data are consistent with the previous experiments, which demonstrated that a balance between dorsal Wnt and ventral Shh signals is essential in order to promote the regional identity within the otic epithelium and to coordinate the morphogenesis of the vestibular (dorsal) and auditory (ventral) organs (Riccomagno et al. 2005). It remains to be studied to what extent the mechanism of Wnt interaction with other pathways is involved in the induction and patterning of the otic placode-e.g., with FGF-as well as a possible role of canonical Wnt signaling in the late ear and vestibular development. Wnt may interact with FGF via Sox2 (Ohyama et al. 2007).

The pituitary gland is a neuroendocrine organ, which controls a range of vital functions of vertebrates, including body growth, metabolism, lactation in the mammary gland, reproduction, stress response, and aging (for review, see Zhu and Rosenfeld 2004). During early development, two embryonic tissues contribute to pituitary gland formation: the oral ectoderm, which gives rise to the anterior and intermediate lobes, and the pituitary placode, which contributes to the so-called Rathke's pouch (Zhu and Rosenfeld 2004). The posterior pituitary is of neural origin and consists of axons of neurosecretory neurons (Scully and Rosenfeld 2002). The anterior and intermediate lobes of the pituitary gland contain six types of hormone-secreting cells: corticotropes /which secrete adrenocorticotropic hormone), thyrotropes (secreting thyroid-stimulating hormone), somatotropes (growth hormone), lactotropes (prolactin), gonadotropes (luteinizing hormone and follicle-stimulating hormone), and melanotropes (melanocyte-stimulating hormone). Specification of the somatotrope, lactotrope, and thyrotrope lineages depends on the essential POU-class homeodomain transcription factor Pit1 (Olson et al. 2006). Conditional loss-of-function mutations of the $\beta$-catenin gene in pituitary progenitors, using Pitxl cre, resulted in a complete loss of Pit1 lineage derivatives and in the loss of expression of Pit1 itself (Olson et al. 2006). Conditional gain-of-function mutations of $\beta$-catenin, again using Pitxl cre, did not block initial organ commitment at E9.5, but at later developmental stages, the whole gland was absent. In contrast, in loss-of-function mutations of $\beta$-catenin using Pit1 cre, the somatotrope, lactotrope, and thyrotrope lineages were still formed, which indicates that Wnt $/ \beta$-catenin signaling is not required for their maintenance (Olson et al. 2006). In this study, a novel mechanism of $\mathrm{Wnt} / \beta$-catenin signaling was identified: $\beta$-catenin directly associates with the paired-like homeodomain transcription factor Prophet of Pit1 (Prop1) to activate Pit1 expression. This has been confirmed in Prop $1^{-/-}$mice, which, indeed, display absence of the three pituitary lineages. Previous work demonstrated that earlier in pituitary development, Wnt $/ \beta$ catenin signaling controls proliferation of the pituitary progenitors by directly regulating expression of the essential gene Pitx2 (Fig. 6; Kioussi et al. 2002). Activation of Wnt signaling leads to the binding of $\beta$-catenin and other coactivator complexes to the Pitx2 promoter (Fig.
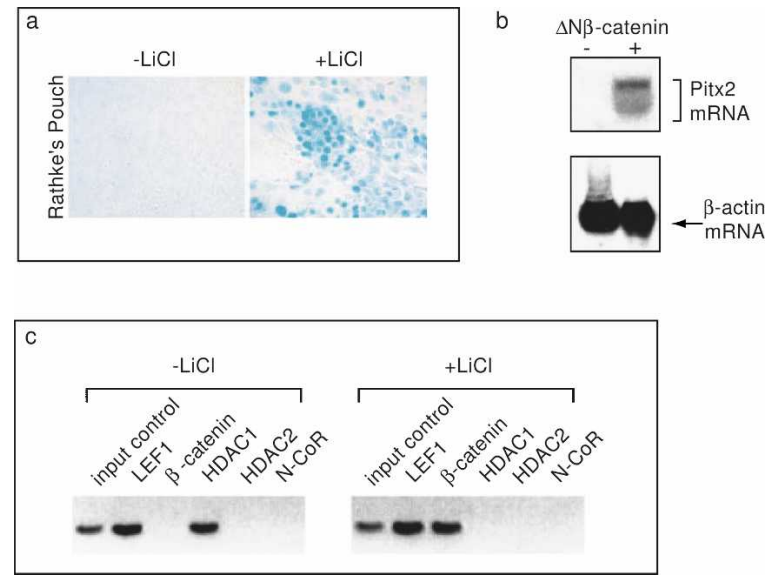

Figure 6. Wnt $/ \beta$-catenin pathway directly induces Pitx 2 expression in the pituitary gland. (a) $\mathrm{LiCl}$ addition to the primary cell culture prepared from E10.5 pituitary glands leads to activation of the Pitx2-driven LacZ expression. $(b)$ Overexpression of the constitutively active $\beta$-catenin ( $\Delta \mathrm{N}-\beta$-catenin) in the $\alpha \mathrm{T}_{3}-1$ pituitary cell line leads to activation of Pitx 2 gene expression. (c) Chromatin immunoprecipitation analysis demonstrated that in the LiCl-stimulated cells, $\beta$-catenin binds to the Pitx2 promoter together with LEF1, whereas in the LiCl-unstimulated cells, LEF1 binds to the Pitx2 promoter along with HDAC1. Reprinted from Kioussi et al. (2002) with permission from Elsevier. 
6c), which then induces expression of the genes that control the cell cycle, such as cyclin D2. Thus, in the pituitary gland, canonical Wnt signaling acts at different developmental stages through different mechanisms: Tcf/ Lef-dependent and Prop1-dependent. Additionally, in the complex with Prop1, $\beta$-catenin can act as a binary switch, activating Pit1 and simultaneously inhibiting another paired-like homeodomain protein, Hesxl (Olson et al. 2006). Among Wnt ligands that act upstream of $\beta$-catenin in pituitary gland development, Wnt 4 and Wnt5a are possible candidates. However, single as well as the double knockout of the genes encoding these ligands did not induce a dramatic phenotype (Treier et al. 1998; Cha et al. 2004). Further mechanisms of canonical Wnt signaling upstream of $\beta$-catenin remain to be elucidated.

In conclusion, Wnt signaling plays diverse roles in sensory placode derivatives. In early stages of taste bud development, Wnt signaling is required to induce taste papilla formation, whereas in the later stages, it plays a role in taste bud maintenance. In contrast, during lens and otic placode development, Wnt signaling is not required for the initial placode induction. In the lens, Wnt activity needs to be repressed, whereas in the surrounding ectoderm, it needs to be activated in order to restrict the lens-forming field. In the otic placode, Wnt signaling is required at later stages to maintain placode identity and $\mathrm{D}-\mathrm{V}$ patterning. In the pituitary, different mechanisms of Wnt function could be identified: On the one hand, Wnt signaling regulates early pituitary progenitor proliferation via Tcf/Lef-dependent regulation of Pitx2, and on the other hand, regulates specification of the Pit1-expressing cells lineages via a Prop1-dependent mechanism.

\section{Wnt/ $\beta$-catenin signaling in somitogenesis}

Somites originate from presomitic mesoderm during the process of body axis elongation of vertebrate embryos. Somites are transient structures that, later in development, give rise to bones, joints, muscles, and connective tissue of the axial skeleton (Saga and Takeda 2001). In all vertebrates, somites are generated sequentially along the A-P axis at fixed time intervals (every $2 \mathrm{~h}$ in the mouse). Such a mechanism requires strict spatial and temporal regulation, which is accomplished by a rhythmic molecular mechanism, the so-called somitic clock. The somitic clock consists of a gradient of signaling factors such as Fgf8 and Wnt3a, and an oscillator. The latter can be visualized by an oscillating expression of genes along the presomitic mesoderm. The oscillation wave sets in at the caudal end of the embryo, where presomitic mesoderm cells are formed. As the embryo grows caudally, cells move out of the gradient of the signaling factors and start to form a segment according to positional information provided by the oscillating genes. Meanwhile, the embryo maintains a constant amount of unsegmented mesoderm by proliferation at the caudal tip. Since the molecular oscillating clock in combination with the morphogen gradient defines the regular boundary positions between the somites, this model of somitogenesis is often referred to as the "clock and gradient model"
(Saga and Takeda 2001; Aulehla and Herrmann 2004; Giudicelli and Lewis 2004). The role of Wnt signaling in somite boundary formation was initially established by experimental up-regulation or down-regulation of Wnt3a signals in the mouse presomitic mesoderm, which led to the formation of smaller or larger somites, respectively. These experiments also demonstrated oscillations of Wnt target genes such as Axin2 (a negative feedback regulator of Wnt signaling) (Lustig et al. 2002), and suggested a role of Wnt3a/ $\beta$-catenin genetically upstream of the Notch signaling pathway (Aulehla et al. 2003).

Loss- and gain-of-function mutations of $\beta$-catenin were recently used to study the complex role of canonical Wnt signaling in somitogenesis. Loss-of-function mutations of $\beta$-catenin were introduced into paraxial mesoderm precursors, using Brachyury cre (Table 1; Aulehla et al. 2008; Dunty et al. 2008). Mutant embryos displayed severe posterior axis truncation with very few abnormally formed somites, whereas the anterior paraxial mesoderm was thickened and unsegmented. Posterior presomitic mesoderm markers such as Brachyury, Tbx6, and Fgf8 were absent (Fig. 7a,b). Moreover, expression of Mesp2, an essential gene in somite boundary formation, was lost or mislocalized in $\beta$-catenin loss-offunction mutants (Fig. 7d,e). The expression of Wnt- and Notch-associated oscillating genes such as Axin2, lunatic fringe, and Hes7 was extinguished in loss-of-function mutants. In contrast, when gain-of-function mutations of $\beta$-catenin were introduced using the same cre, mutant embryos showed delayed and defective formation of somites and an expansion of presomitic mesoderm. No difference in proliferation was observed. The expression of Wnt target genes involved in the presomitic mesoderm patterning such as Tbx6, mesogenin1, and Dll1 was up-regulated and shifted anteriorly (Fig. 7a,c). Expression of Mesp2 was shifted anteriorly and appeared in multiple stripes (Fig. 7d,f). Surprisingly, the constitutive activation of $\beta$-catenin did not block expression of Wntor Notch-regulated oscillating genes, as demonstrated,

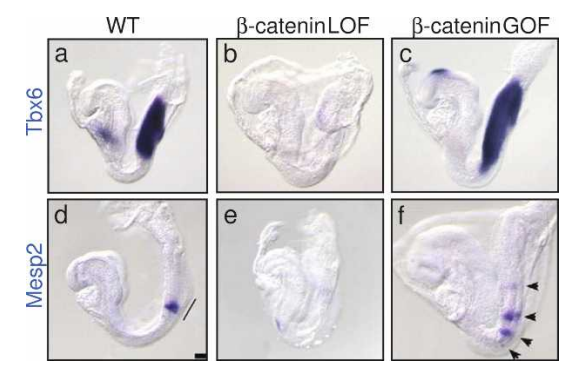

Figure 7. Wnt $/ \beta$-catenin signaling in somitogenesis. $(a, b)$ Conditional loss-of-function mutations of $\beta$-catenin result in anterior mesoderm thickening, posterior truncation and prevention of somitogenesis. $(a, b)$ Tbx6, a marker for posterior presomitic mesoderm, is lost in loss-of-function mutants. Conditional gain-of-function mutations of $\beta$-catenin result in posterior mesoderm expansion shown by expanded Tbx6 expression $(a, c)$. $(d-f)$ Expression of Mesp2 is lost in loss-of-function mutants $(d, e)$, and appears in multiple stripes in gain-of-function mutants $(d, f)$. Reprinted by permission of the Company of Biologists from Dunty et al. (2008). 
for instance, by real-time imaging using lunatic fringe as a reporter and other methods. Markers for somite polarity, such as Tbx18 and Uncx4.1, continued to be expressed in both loss- and gain-of-function mutants, indicating that $\mathrm{Wnt} / \beta$-catenin signals are not essential to establish somite polarity (Aulehla et al. 2008). Finally, a microarray analysis identified a new somite boundary determination gene, Ripply2, which acts downstream from Wnt and Mesp2 to regulate segment boundary formation (Dunty et al. 2008).

These experiments have demonstrated a crucial role for nuclear $\beta$-catenin in defining the size of the oscillary field at the posterior tip of the embryo and assigned additional roles to $\mathrm{Wnt} / \beta$-catenin signals in mesoderm patterning. In these processes, $\beta$-catenin protein does not cycle, but forms a nuclear-to-cytoplasmic gradient. However, the transcriptional activity of nuclear $\beta$-catenin may be modulated by oscillating cofactors. Of note, oscillating Wnt signaling activity has recently also been demonstrated in the skin, where it is required for proper hair cycle progression (Plikus et al. 2008). The functional significance of oscillating Wnt target genes as well as the detailed mechanisms of Wnt function in these complex processes remain to be determined.

\section{Wnt/ $\beta$-catenin signaling in bone and cartilage}

Canonical Wnt signals play an essential role in skeletogenesis. The mammalian skeleton is composed of two types of tissues, bone and cartilage. Bone, in turn, is formed by two major types of cells, osteoblasts and osteoclasts. Cartilage is formed by chondrocytes. Osteoblasts and chondrocytes originate from common osteochondrogenic progenitor cells of mesenchymal origin. Osteoclasts are cells of hematopoietic origin that take part in resorption of the newly formed bone (for review, see Karsenty and Wagner 2002; Hartmann 2006). The role of canonical Wnt signaling at different stages of skeletogenesis has been proposed based on the expression patterns of many Wnt pathway members, as well as Wnt reporter expression in the mouse (Parr et al. 1993; Guo et al. 2004; Day et al. 2005; Hens et al. 2005; Hill et al. 2005; Hu et al. 2005).

The contribution of Wnt signaling during early skeletogenesis has recently been explored through conditional loss- and gain-of-function mutations of $\beta$-catenin (Table 1). $\beta$-Catenin loss-of-function mutations were introduced into osteo-chondrogenic progenitor cells using Prx1 and Dermol cre, and resulted in early osteoblast differentiation arrest, increased chondrogenesis, and ectopic cartilage formation (Day et al. 2005; Hill et al. 2005; Hu et al. 2005). Conversely, gain-of-function mutations of $\beta$-catenin in the osteo-chondrogenic progenitors using Prx1 cre resulted in the arrest of chondrogenesis (Hill et al. 2005). Furthermore, $\beta$-catenin loss- and gain-of-function mutations were introduced in micromass cultures of early limb buds prepared from $\beta$-cate$\operatorname{nin}^{\mathrm{Wbm} / \mathrm{flox}}$ and $\beta$-catenin ${ }^{\mathrm{Mmt} / \text { flox }}$ embryos that were then infected with adenoviral cre. $\beta$-Catenin loss-offunction mutations in these micromass cultures resulted in an increase in the expression of the chondrogenic marker Sox 9 and precocious differentiation into chondrocytes, whereas $\beta$-catenin gain-of-function mutations led to the decrease of Sox9 expression and suppressed chondrogenesis. This indicates that $\mathrm{Wnt} / \beta$-catenin signaling negatively regulates differentiation of mesenchymal cells into chondrocytes. Moreover, adenoviral cremediated ablation of $\beta$-catenin in calvarial mesenchymal progenitor cell cultures inhibited osteoblast differentiation and allowed chondrocyte differentiation, demonstrating that Wnt/ $\beta$-catenin signaling acts cell-autonomously to promote osteo-chondrogenic progenitor cells to differentiate into the osteoblast lineage (Hill et al. 2005).

Loss- and gain-of-function mutations of $\beta$-catenin using Collagen-1a cre have revealed an additional function for Wnt signaling in these processes (Table 1). It plays a role in osteoblasts that have already differentiated: Overexpression of $\beta$-catenin resulted in a negative effect on bone resorption and osteoclast differentiation. Mutant mice displayed a decrease in osteoclast numbers, resulting in a dramatic increase in bone mass as well as altered tooth development (Glass et al. 2005). Osteoclast differentiation was affected in both loss- and gain-of-function mutants due to the deregulation of the osteoprotegerin gene. Osteoprotegerin was proposed to be a direct target of Wnt signaling in osteoblasts, regulated by Tcf1 (Glass et al. 2005; Jackson et al. 2005). This was a novel finding in that $\beta$-catenin may act in a non-cell-autonomous manner (Glass et al. 2005). Similar results were observed in experiments where loss- and gain-of-function mutations of $\beta$-catenin in osteoblasts were introduced with an osteocalcin cre (Holmen et al. 2005). Recently, loss- and gain-of-function mutations of $\beta$-catenin using Osx 1 cre have been used to demonstrate that commitment within the osteoblast lineage requires strictly regulated Wnt pathway activity and a stage-specific genetic interaction between Wnt and Indian Hedgehog (Ihh) pathways (Hu et al. 2005; Mak et al. 2006; Rodda and McMahon 2006). Apparently, in osteoblast differentiation, $\beta$-catenin acts downstream from Ihh signaling, whereas in chondrocyte survival, $\beta$-catenin acts upstream of Ihh to inhibit chondrocyte apoptosis (Mak et al. 2006). Finally, using lossand gain-of-function mutations of $\beta$-catenin, it has been demonstrated that direct interaction between $\beta$-catenin and Sox 9 is essential to control chondrocyte maturation (Akiyama et al. 2004). Overall, in early bone development, Wnt/ $\beta$-catenin signaling mediates lineage decisions of the osteo-chondrogenic progenitors, directing them to adopt an osteoblast fate. At later stages, Wnt signaling is required for the osteoblast maturation and, indirectly for bone resorption.

\section{Wnt/ $\beta$-catenin signaling in organs that contain branching epithelia}

Canonical Wnt signaling is essential in many aspects of tissue branching in organs like kidney, lungs, and mammary gland (Table 1). The development of the mammalian metanephric kidney starts when the nephric (Wolffian) duct of mesodermal origin invaginates to form the 
ureteric bud (UB), which consequently begins to extend, invade the adjacent metanephric mesenchyme, and branch in a stereotypic pattern (for review, see Ekblom 1996; Saxen 1999). At the same time, a group of specified progenitors within metanephric mesenchyme condenses and forms a cap around the tips of the extending and branching UB. Mutual inductive interactions between UB and metanephric mesenchyme are crucial for proper kidney morphogenesis. A population of cells within this condensed tissue further undergoes mesenchymal-to-epithelial transition and forms renal vesicles that proceed through a series of morphogenic transformations, giving rise to the S-shaped bodies, glomeruli, and, ultimately, to most of the nephron structure. The UB derivatives contribute to the collecting duct system and future ureter. Thus, the nephron represents a minimal functional unit of the kidney (Costantini 2006; Merkel et al. 2007). Wnt signaling has been proposed to play a role in kidney morphogenesis due to the expression of several Wnt ligands at the various stages of development in the Wolffian duct, UB and branch tips, and metanephric mesenchyme (Stark et al. 1994; Itaranta et al. 2002; Carroll et al. 2005; Iglesias et al. 2007). Moreover, Wnt9b, Wnt4, or Wnt11 gene ablation revealed a critical role of Wnt ligands in kidney induction, morphogenesis, and branching, and their interaction with other pathways (Stark et al. 1994; Majumdar et al. 2003; Carroll et al. 2005).

Conditional mutations of $\beta$-catenin in different cell populations of the developing kidney allowed an analysis of the role of canonical Wnt signaling in kidney morphogenesis (Table 1). Loss-of-function mutations of $\beta$-catenin were introduced in the population of progenitors within metanephric mesenchyme using Six2GFP cre (Park et al. 2007). $\beta$-Catenin mutant mice showed a reduced kidney size with very few mature nephron structures and reduced branching. The reduced expression of early mesenchymal induction markers such as Fgf8, Wnt4, Pax8, and Lhx1 was also observed. The investigators suggest that residual marker expression results from cells that have escaped recombination. Furthermore, gain-of-function mutations of $\beta$-catenin were introduced in the same cell population using Six2GFP-cre. Mutant mice showed larger kidney size with reduced branching and an absence of epithelial stages of tubulogenesis. The metanephric mesenchyme was grossly enlarged and condensed and showed ectopic and disorganized overexpression of Fgf8, Wnt4, Pax8, and Lhx1. This is in line with a study in which dominant-negative Tcf or stabilized $\beta$-catenin was overexpressed in metanephric mesenchyme in isolated organ culture (Park et al. 2007; Schmidt-Ott et al. 2007). These data indicate that activation of canonical Wnt signaling in the cap mesenchyme of nephron progenitors is sufficient to initiate an ectopic program for early inductive events. The lack of epithelial structures in gain-of-function mutants suggests that a down-regulation of Wnt signaling at later stages of development is needed for proper mesenchymalto-epithelial transitions to occur. This study demonstrated an important role of canonical Wnt/ $\beta$-catenin signaling for the generation of the inductive signal within the metanephric mesenchyme and the consequent development of epithelial structures of the kidney. The study of Park et al. (2007) using loss- and gain-of-function mutations of $\beta$-catenin also allowed exploring the mechanism of action of $\mathrm{Wnt} 9 \mathrm{~b}$ and $\mathrm{Wnt} 4$. It has been previously speculated that Wnt4 may act in noncanonical Wnt signaling in kidney development (Jho et al. 2002; Maretto et al. 2003; Osafune et al. 2006). Park et al. (2007) have demonstrated that $\beta$-catenin gain-of-function mutations can rescue the early stages of nephron induction in both Wnt9b and Wnt4 knockout mice, indicating that both these Wnt ligands act in canonical Wnt signaling in the context of kidney development. This is in line with other studies that indicate a role of Wnt4 in canonical Wnt signaling (Lyons et al. 2004; Carroll et al. 2005). In another study, loss- and gain-of-function mutations of $\beta$-catenin have been introduced in the Wolffian duct epithelium, using Hoxb7 cre (Table 1; Marose et al. 2008). Loss-of-function mutations revealed a range of phenotypes including extreme hypoplasia and cystic kidneys. The UB was completely absent in some cases, and in others, UB branching was severely reduced depending on a degree of $\beta$-catenin ablation. All mutant mice completely lacked metanephric mesenchyme differentiation as well. Adherens junctions were unaffected in the mutants, indicating that $\beta$-catenin functions in the UB and Wolffian duct through canonical Wnt signaling (see also Bridgewater et al. 2008). Expression of Ret and Wnt11, markers for UB branching, was lost. Instead, mutants prematurely expressed differentiation markers such as ZO1 $\alpha$. In contrast, introduction of gain-of-function mutations of $\beta$-catenin using Hoxb7 cre resulted in a suppression of differentiation. Wnt/ $\beta$-catenin signaling is thus necessary to maintain cells of Wolffian duct/UB in an undifferentiated state, controlling the balance between undifferentiated and differentiated states during kidney development.

Lung development begins when the ventral foregut endoderm invaginates to form two lung primordial buds, which consequently begin to extend, invade the adjacent mesenchyme, and branch in a stereotypic tree-like pattern, forming the so-called respiratory bronchial tree (for review, see Hogan 1999). The endoderm gives rise to various epithelial cell types that line the inner surface of the developing lung and trachea, whereas the lung mesenchyme gives rise to the connective tissue of the lung as well as endothelial cell precursors, the smooth muscle around the airways, the cartilage of the trachea, the lymphatics, pulmonary vessels, and the mesothelial cells that cover the outer surface of the lung. Lungs are structurally and functionally divided into two distinct components: the proximal airways that conduct air and the distal airways that mediate gas exchange. Various Wnt pathway components including canonical and noncanonical Wnt ligands are expressed and appear to function at various stages of lung development, both in the lung epithelium and mesenchyme (Hogan 1999). Conditional mutations of $\beta$-catenin in mice have demonstrated that canonical Wnt signaling plays a role at different stages and tissues during lung development (Table 1). Condi- 
tional loss-of-function mutations of $\beta$-catenin in epithelial cells of the embryonic mouse lung, using an inducible surfactant protein $\mathrm{C}$ promoter-driven cre (SP-C cre), resulted in pulmonary malformations with enlarged and elongated proximal airways and inhibited distal airways (Mucenski et al. 2003; Shu et al. 2005). The number of main stem bronchi and their correct branching were not affected in the mutant mice. However, the branching of secondary bronchi was perturbed. In addition, the expression of genes of proximal cells, such as Clara cell secretory protein (CCSP), was expanded, whereas the expression of the genes of distal airways such as SP-C, was reduced (Shu et al. 2005). Expression of Bmp4 and N-myc was absent in mutant cells, and expression of Fgf10 was reduced. This indicates that canonical Wnt signaling may act upstream of those genes in regulating the proximal-distal (P-D) patterning of lungs (Shu et al. 2005). Gain-of-function mutations of $\beta$-catenin, introduced in the lung epithelium using inducible CCSP promoterdriven cre (CCSP cre), demonstrated the opposite phenotype (Mucenski et al. 2005). They induced the ectopic production of peripheral lung cells in conducting airways. Mutant mice displayed epithelial hyperplasia with focal areas of inflammation and developed solid pulmonary tumors of epithelial origin. A new role for Wnt signaling in the lung mesenchyme has recently been suggested on the basis of $\beta$-catenin loss-of-function mutations introduced using Dermol-cre (De Langhe et al. 2008). Mutant embryos showed shortened trachea and reduced abnormal branching. Loss of $\beta$-catenin expression affected progenitors of parabronchial smooth muscle cells. $\beta$-Catenin may act upstream of Pitx 2 in the regulation of expansion of parabronchial smooth muscle cells, as demonstrated by the loss of Pitx 2 expression in $\beta$-catenin mutants and phenotype similarity with Pitx $2^{-/-}$mice. Additionally, mutant mice had abnormally formed blood vessels in the lung, which were lined up with premature angioblasts (De Langhe et al. 2008). In conclusion, conditional loss-of-function mutations of $\beta$ catenin in lung mesenchyme demonstrated that canonical Wnt signaling plays a dual role, promoting expansion of parabronchial smooth muscle cells via binding to Pitx2, and controlling proper differentiation of the angioblasts into mature endothelial cells.

Like other epithelial appendages, mammary glands originate from surface ectoderm and develop through distinct epithelial-mesenchymal interactions (Robinson et al. 1999; Veltmaat et al. 2003; Chu et al. 2004). An important role of Wnt signaling in the mammary gland was suggested by Nusse and Varmus, who identified Wnt1 (int-1) as a proto-oncogene in mouse mammary tumors (Nusse and Varmus 1982). A further role was demonstrated in Lef1 $1^{-/-}$mice, which lacked mammary anlagen (van Genderen et al. 1994). In addition, the overexpression of Wnt1 or Wnt10b under the MMTV promoter resulted in mammary hyperplasias, increased proliferation and branching, and induced tumors (Tsukamoto et al. 1988; Lane and Leder 1997). Conditional gainof-function mutations of $\beta$-catenin have been introduced in mammary alveolar epithelium using the MMTV-long terminal repeat cre (MMTV-LTR cre) or the whey acidic protein cre (WAP cre) (Table 1; Miyoshi et al. 2002; Renou et al. 2003). $\beta$-Catenin gain-of-function mutations resulted in mammary hyperplasias, accompanied by a loss of alveolar structures. Alveolar cells failed to differentiate and instead adopted epidermal fate. No tumor formation was observed. In contrast, overexpression of other forms of stabilized $\beta$-catenin, such as $\Delta \mathrm{N} 57$-, $\Delta \mathrm{N} 89$-, and $\Delta \mathrm{N} 90-\beta$-catenin under control of the K5 or MMTV-LTR promoter, resulted in the formation of mammary gland tumors (Imbert et al. 2001; Michaelson and Leder 2001). Precocious alveolar differentiation was also observed. The difference in phenotypes observed in these mouse models has been attributed to different levels of transcriptionally active $\beta$-catenin (Miyoshi and Hennighausen 2003). So far, no data have been reported on conditional $\beta$-catenin loss-of-function mutants in the mammary gland. In summary, different $\beta$-catenin mouse models have been successfully used to determine the involvement of $\mathrm{Wnt} / \beta$-catenin signaling in cell fate decisions and the proper development of the mammary gland. The data demonstrate that activated Wnt $/ \beta$ catenin signaling is dominant over intrinsic differentiation programs and can lead to an epidermal fate or neoplasias in various cell types.

\section{Wnt/ $\beta$-catenin signaling in hematopoiesis}

Hematopoietic stem cells (HSCs) are a class of multipotent stem cells that arise from common progenitors of mesodermal origin. During hematopoiesis, HSCs produce long- and short-term HSCs, which give rise to all types of differentiated blood cells of myeloid, lymphoid, and erythroid lineages (for review, see Weissman et al. 2001; Staal and Clevers 2005). Ontogenetically, hematopoiesis occurs in two major waves: primitive and definitive hematopoiesis. The first wave of primitive hematopoiesis takes place in the yolk sacs and generates transient populations of progenitors able to differentiate into nucleated erythroid and macrophage lineages. The second wave of definitive hematopoiesis gives rise to a full range of blood cells during late development and through adulthood. This population of definitive multipotent progenitors resides mainly in the fetal liver-the major hematopoietic organ in embryogenesis. In adults, the major organ for the hematopoiesis and HSC maintenance is the bone marrow (for review, see Kondo et al. 2001; Weissman et al. 2001). Canonical Wnt signaling was previously suggested to play an important role in proliferation and maintenance of HSCs, as well as in maturation of progenitors of B- and T-lymphocytes (van Genderen et al. 1994; Verbeek et al. 1995). Further evidence for the role of Wnt signaling in HSCs proliferation and self-renewal came from studies by the groups of Nusse and Weissman, who activated Wnt signaling in HSCs by stimulation with Wnt3a or overexpression of stabilized $\beta$-catenin (Reya et al. 2003; Willert et al. 2003). Evidence that Wnt signaling plays a role in T- and B-cell development came from studies of $\mathrm{Tcf}^{-/-}$and Lef1 $1^{-/-}$ mice (van Genderen et al. 1994; Verbeek et al. 1995). 
To study the role of Wnt signaling in T-cell development, $\beta$-catenin loss- and gain-of-function mutations were introduced in premature thymocytes using Lck cre (Table 1; Gounari et al. 2001; Mulroy et al. 2003; Xu et al. 2003). T-cell development was blocked in $\beta$-catenin lossof-function mutants. In $\beta$-catenin gain-of-function mutant mice, T-cell development was accelerated; however, the mutant $\mathrm{T}$ cells lacked the $\mathrm{T}$-cell receptor complex TCR-CD3, indicating that correct thymocyte maturation was prevented. To study the role of Wnt signaling at earlier stages in HSCs, gain-of-function mutations of $\beta$ catenin were introduced, using interferon-inducible $\mathrm{Mx}$ cre. This resulted in a disruption of balance between long-term and short-term HSCs, and a block of differentiation into all hematopoietic cell lineages (Kirstetter et al. 2006; Scheller et al. 2006). The HSCs lost their quiescent state and showed increased proliferation. The differentiation failure of the mutant HSCs may be a result of excessive cycling and exhaustion of the long-term HSC pool (Scheller et al. 2006). $\beta$-Catenin loss-of-function mutations using vav cre also lead to impaired selfrenewal of the HSCs (Zhao et al. 2007). Surprisingly, combined absence of $\beta$-catenin and plakoglobin $(\gamma$ catenin) did not cause any defects in development of all immature and mature subsets of all hematopoietic lineages, or in reconstitution of long- and short-term HSC populations, as demonstrated in chimeric bone marrow transplants (Jeannet et al. 2008; Koch et al. 2008). Remarkably, canonical Wnt signaling remained active in the absence of $\beta$-catenin and plakoglobin ( $\gamma$-catenin), as demonstrated in Wnt-reporter mice (Jeannet et al. 2008). Based on previous data that Lef1 and Tcf1, the downstream transcription factors of canonical Wnt signaling, are essential for proper hematopoiesis (van Genderen et al. 1994; Verbeek et al. 1995) and that the N-terminal domain of Tcf1, containing the $\beta$-catenin-binding site, was essential to rescue thymocyte development in Tcf1 ${ }^{-/-}$mice (Ioannidis et al. 2001), it has been suggested that a yet-unidentified factor capable for binding the $\mathrm{N}$ terminus of Tcf1 is likely to be responsible for Wnt activity in hematopoiesis in the absence of both $\beta$-catenin and plakoglobin ( $\gamma$-catenin). More work is needed on this novel mechanism for Wnt pathway functions. Recently, a remarkable study by Reya and colleagues (Zhao et al. 2007) showed that $\beta$-catenin loss-of-function mutations in HSCs using vav cre prevented the development of BcrAbl-induced chronic myelogenous leukemia. These studies demonstrated that canonical Wnt signaling is required for the self-renewal of hematopoietic cancer stem cells.

\section{Wnt/ß-catenin signaling in the limb}

Canonical Wnt signaling also plays important roles at different stages of limb development. Limb buds of vertebrates form from limb primordia, determined groups of cells at specific locations along the embryo body. Limb bud outgrowth and patterning are established along three cardinal axes and require coordinated interactions between distinct signaling centers: The apical ectodermal ridge (AER) controls $\mathrm{P}-\mathrm{D}$ elongation of the limb buds (from shoulder to finger tip); the zone of polarizing activity (ZPA) controls A-P patterning (from thumb to little finger); and the limb bud ectoderm directs $\mathrm{D}-\mathrm{V}$ axis formation (back of the hand to palm) (for review, see Capdevila and Izpisua Belmonte 2001; Niswander 2003). Wnt signals participate in the patterning of both AER and $\mathrm{D}-\mathrm{V}$ axis formation. In the chick, limb formation is initiated by Wnt2b and Wnt $8 \mathrm{c}$ in the lateral plate mesoderm to restrict the expression of Fgf10 to the prospective limb mesoderm. Fgf10 then induces the expression of Wnt3a (Wnt3 in the mouse) in the limb ectoderm that is required for Fgf8 expression in the presumptive AER (Kawakami et al. 2001; McQueeney et al. 2002; Barrow et al. 2003).

In order to study the role of Wnt/ $\beta$-catenin signaling in the surface ectoderm of limbs, loss- and gain-of-function mutations of $\beta$-catenin were produced using Msx 2 cre (Barrow et al. 2003) or Brain 4 cre (Table 1; Soshnikova et al. 2003). Cre-induced loss-of-function mutation of $\beta$-catenin resulted in severe malformations or complete absence of limbs. In limbs of mildly affected mutants, ventral dermal pads were absent, and circumferential nails were detected. The mutant mice thus displayed an absence of ventral and duplication of dorsal structures. These data indicated that Wnt/ $\beta$-catenin signaling is essential in the surface ectoderm of limbs for both AER (P-D axis) and D-V axis formation. These phenotypes are similar to those obtained when the BmpR1a was ablated conditionally (Ahn et al. 2001). In order to analyze the epistatic interaction between Wnt and Bmp signaling in P-D and D-V patterning of the limb, our lab generated compound mutants in which conditional gain-of-function mutations of $\beta$-catenin and loss-of-function mutations of the BmpRla were introduced in the limb ectoderm, using Brain 4 cre (Soshnikova et al. 2003). Remarkably, in these compound mutants, the area of the AER, the expression domains of Fgf 8 and Bmp4, and the overall size of the limbs were strongly enlarged (Fig. 8a). This was also observed in embryos that carry only the $\beta$-catenin gain-of-function mutation. These data demonstrated that Wnt/ $\beta$-catenin signaling is located downstream from Bmp signaling in AER (P-D) patterning of the limb. Moreover, we examined these compound mutant embryos for the expression of Engrailed 1 (En1) and Wnt7a, which are expressed along the D-V axis. Remarkably, in the compound mutants, En 1 expression in the ventral ectoderm was absent, and Wnt7a was expressed in both dorsal and ventral ectoderm, as it was observed in single loss-of-function mutants (Fig. 8b). Thus, both ectodermal $\beta$-catenin and BmpR1a are required for correct specification of the ventral character in limb ectoderm. However, enhanced $\beta$-catenin signaling does not rescue the deficits caused by the BmpRla loss-of-function mutation, suggesting that genetically, $\beta$-catenin acts upstream to the BmpRla during $\mathrm{D}-\mathrm{V}$ patterning (Soshnikova et al. 2003).

The finding that the hierarchies of Wnt and Bmp signaling were different in the formation of two different axes in the limb was remarkable. It showed that in the 
Figure 8. Wnt/ $\beta$-catenin signaling in limb patterning. (a) At 42 somite stage AER is absent or severely reduced in $\beta$-catenin loss-of-function mutants $(\beta$ cat $^{\text {flox }}$, and expanded in the gain-of-function mutants $(\Delta \mathrm{N}-\beta$-cat $)$, as shown by Fgf8 and Bmp4 expression. AER is not formed in BmpRla loss-of-function mutants $\left(B m p R 1 A^{\text {flox }}\right)$ at 42 somite stage. In compound mutants with loss-of-function mutations of BmpR1a and gain-of-function mutations of $\beta$-catenin AER is expanded, resembling the phenotype of single $\beta$-catenin gain-of-function mutants. This indicates that canonical Wnt signaling acts downstream from Bmp signaling in AER formation. (b) At 30 somite stage expression of the ventral gene En1 is lost and expression of the dorsal gene Wnt7a is expanded ventrally in $\beta$-catenin loss-of-function mutants. In contrast, in gain-of-function mutants, expression of these markers is unchanged. In BmpR1a loss-of-function mutants, as well as in compound mutants, phenotypes resemble that of $\beta$-catenin loss-of-function mutants, indicating that canonical Wnt signaling acts upstream of, or in parallel to the Bmp signaling in D-V patterning of the limb. All gene mutations were introduced using Brain 4 cre. Reprinted with permission from Soshnikova et al. (2003).

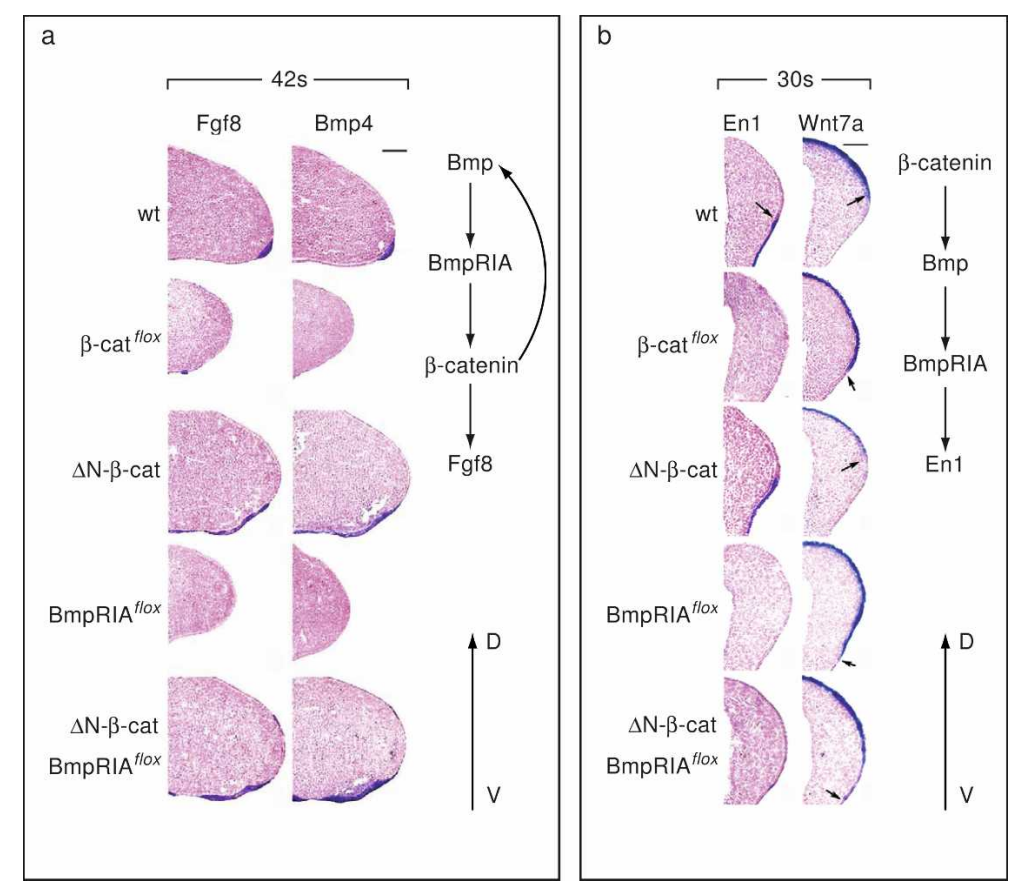

development of one organ, hierarchies of signaling pathways can be different in particular processes, even if they occur at the same time. The intricate interactions between Wnt/ $\beta$-catenin and Bmp signaling in the limb ectoderm provide the molecular basis that ensures a tight spatial-temporal control of signaling responses and may connect the development of P-D and D-V axes.

\section{Conclusions: lessons from conditional loss- and gain-of-function $\beta$-catenin mutant mice}

Genetic analysis in mice, particularly the use of conditional loss- and gain-of-function mutations of $\beta$-catenin in various tissues and organs, demonstrated that canonical Wnt signals play key roles in the maintenance and expansion of embryonic progenitor cells and stem cells. Of particular interest are recent findings on the functions of canonical Wnt signals in the maintenance of cancer stem cells. For instance, in ras-induced squamous cell carcinomas of the skin, loss-of-function mutations of $\beta$-catenin lead to tumor regression, demonstrating that maintenance of the cancer stem cell population is dependent on $\beta$-catenin signaling. Conversely, an increase in the number of mammary cancer stem cells was found in premalignant mammary glands of MMTVWnt1 transgenic mice (Shackleton et al. 2006). These functions of Wnt signaling in cancer stem cells of the skin and mammary gland are analogous to those described recently in cancer stem cells of the hematopoietic system.

In addition, Wnt/ $\beta$-catenin signals help direct cells toward particular fates. This review includes examples of loss- and gain-of-function mutations, where canonical Wnt signals instruct cells to generate hair but not epi- dermis (skin), enterocytes and Paneth cells but not goblet cells (intestine), osteoblasts but not chondrocytes (bone), and the second but not the first heart field. In several tissues, like the intestine, the pituitary, and the nervous system, Wnt signals control in parallel self-renewal of those progenitors, which they also direct to adopt a particular fate. In particular, in the nervous system, Wnt signals direct differentiation, for instance, by directing a sensory neuronal fate or pattern in the spinal cord. In parallel, they allow the maintenance and expansion of the corresponding progenitor pool. Similarly, in the pituitary, Wnt signaling maintains the progenitor pool and directs differentiation of the Pit1-expressing lineages. The opposing effects of the $\beta$-catenin gain- and loss-of-function mutations are particularly useful in the characterization of such dual functions: Frequently, the instructive role of canonical Wnt signaling can be analyzed only by gain-of-function mutations, which show the expansion of lineages at the expense of others, while in loss-of-function mutations, the depletion of a progenitor pool prevents such an analysis.

Studies of these themes have been complicated by the dual role $\beta$-catenin can have in canonical Wnt signaling and in cadherin-mediated cell adhesion (Takeichi 1991; Kemler 1993; Gates and Peifer 2005). In many cases, $\beta$ catenin loss-of-function mutations affect the integrity of the targeted tissues. It had been shown that plakoglobin $(\gamma$-catenin), which is the closest relative of $\beta$-catenin in the Armadillo protein family, can take over the function of $\beta$-catenin in cell adhesion in the loss-of-function $\beta$ catenin mutations. This happens, for instance, in the early mouse embryo (Huelsken et al. 2000), in the epidermis (Posthaus et al. 2002), or in the heart (Zhou et al. $2007)$. In other cases, mutations of $\beta$-catenin clearly re- 
sulted in disintegration of tissues due to defective adhesion (Junghans et al. 2005; Smith et al. 2005). In each single case, it must be determined whether the effects of $\beta$-catenin are mediated by Wnt-controlled transcriptional events or by cell adhesion defects. Here gain-offunction mutations of $\beta$-catenin have been essential in revealing the role of canonical Wnt signaling, by producing phenotypes opposite to loss-of-function experiments.

A range of target genes of $\mathrm{Wnt} / \beta$-catenin signaling have been identified (see also http://www.stanford.edu/ - rnusse/wntwindow.html), but so far only a few have been proven to be direct and/or essential targets. For instance, the negative regulator of canonical Wnt signals, Axin2/Conductin, is a direct target. Our Axin2-LacZ reporter mouse, which expresses lac $Z$ under the control of the endogenous Axin2 promoter, has turned out to be very useful to monitor endogenous canonical Wnt signals in many tissues and organs (Lustig et al. 2002; Soshnikova et al. 2003; Zechner et al. 2003, 2007). It has been a decade since c-Myc was identified as a direct target of canonical Wnt signals in the intestine. Recently, a thorough mechanism of regulation of the c-Myc promoter by the $\beta$-catenin transcriptional complex has been described (Sierra et al. 2006). The physiological importance of c-Myc as an essential Wnt target was also corroborated genetically: The conditional ablation of c-Myc rescued the phenotype of the APC deletion in the intestine. Another gene, Pitx2, was identified as a direct and essential target of canonical Wnt signaling in the pituitary gland, the heart, the pancreas, and the lung. Further essential targets of Wnt signaling include Mitf1 in the melanocyte lineage, Olig3 in the dorsal spinal cord, Ptfla in the pancreas, and Fgf10 in the second heart field, the pancreas, and lung. Finally, we should mention two exotic cases: Prop1 is a transcription factor that directly interacts with $\beta$-catenin instead of Tcf/Lef factors to control Wnt/ $\beta$-catenin-dependent signaling in particular pituitary sublineages. And in hematopoiesis, Wnt/Tcf-dependent target gene activation can occur independently of $\beta$-catenin and plakoglobin ( $\gamma$-catenin). Comprehensive identification of direct and essential targets of canonical Wnt signaling, and of the mechanisms by which $\beta$-catenin regulates the transcription of those genes, remains an important aspect to address in the future.

We discussed several examples in which Wnt/ $\beta$ catenin and other signaling systems act on each other in a hierarchical manner. The hierarchies in which these signaling pathways interact can vary. For instance, in the establishment of the axes in the limb, Bmp signals act upstream of or downstream from $\mathrm{Wnt} / \beta$-catenin, depending on the context. In addition, the multipotent state of neural crest cells requires activity of both Wnt and Bmp signaling, and Bmp appears to antagonize the signal provided by Wnt/ $\beta$-catenin. Wnt and Bmp signals also cooperate to maintain quiescent skin stem cells. Oscillating expression of Bmps in normal skin regulates oscillations in Wnt signaling to ensure periodic activation of the bulge stem cells and allow coordinated hair differentiation during the hair cycle. Oscillations of Wnt and Notch signaling activities in strictly opposite phases have been demonstrated to be crucial for somitogenesis. This indicates that the mechanism must be tightly regulated. During skeletogenesis, commitment within the osteoblast lineage requires strictly regulated stage-specific genetic interaction between Wnt and Indian Hedgehog (Ihh) pathways. Apparently in osteoblast differentiation, $\beta$-catenin acts downstream from Ihh signaling, whereas in chondrocyte survival, $\beta$-catenin acts upstream of Ihh to inhibit chondrocyte apoptosis. Sonic hedgehog acts upstream of Wnt/ $\beta$-catenin in the taste bud specification. These intricate interactions of canonical Wnt with other signaling systems provide the molecular basis for tight spatio-temporal control of the consecutive steps of developmental processes.

In cases in which specific cre mice have been available, studies of $\beta$-catenin loss of function and gain of function have been fruitful. In the future, these studies can be extended to studying the role of canonical Wnt signaling in further aspects of embryonic development, for example, in the brain, thanks to the ongoing development of many more cre mice (for instance, see http:// www.gensat.org/cre.jsp). This will allow us to study the pathway's effects on specific precursor populations and will permit a precise mapping of the regulatory networks of developmental signaling pathways in the different tissues and organs and at particular time points, as well as in regulating adult stem cells in organs such as the skin, intestine, and the hematopoietic system. Regulatory networks are also complex in tumors: For instance, Wnt $/ \beta$ catenin signaling acts downstream from ras signaling in epidermal tumors (Malanchi et al. 2008), which is opposite to the situation in intestinal tumors (Kinzler and Vogelstein 1996). Deeper research into canonical Wnt signaling will be needed to deal with these complexities, as well as to reveal further direct and essential target genes of the Wnt pathway. We expect that the large collection of mouse models presently available, in particular, the gain-of-function mutants, will be of use for the testing and improvement of Wnt-modulating agents.

Finally, it is important to remember that conditional mutagenesis of $\beta$-catenin was first used in 1999, but important functions of canonical Wnt signals in several tissues were identified earlier. For instance, in the intestine, a great deal of information on the role of Wnt signaling was generated in the 1990s by the analysis of APC functions in tumor formation. However, very important recent findings obtained from the use of the loss- and gain-of-function mutations in $\beta$-catenin reveal the role of canonical Wnt signaling in stem cell and cancer stem cell maintenance and lineage decisions. Altogether, the use of conditional $\beta$-catenin mutant mice has demonstrated that canonical Wnt signals are used over and over again in development and maintenance of organs. It remains astonishing to us that such a wide array of diverse biological functions is mediated by a single signaling mechanism. On the other hand, the system provides an excellent model of the way evolution has used a module over and over again to achieve a wide variety of similaryet subtly unique-effects within the tissues of multicellular organisms. As our knowledge of the uses and 
regulation of this system deepens, this will permit the development of further powerful animal models of human development and disease processes.

\section{Acknowledgments}

We thank Carmen Birchmeier (Berlin) and Russ Hodge (Berlin) for helpful discussions and improvements on the text. We are grateful to C. Hartmann (Vienna), M. Morkel (Berlin), H. Schrewe (Berlin), N. Soshnikova (Geneva), K. Schmidt-Ott (Berlin), F. Spagnioli (New York), and M. Scheller (Berlin) for looking through particular sections. We also thank Marina Grigoryan for the graphical editing of the figures. Our work is funded by the Deutsche Forschungsgemeinschaft (DFG), the German Cancer Aid (Deutsche Krebshilfe), and the Federal Ministry of Education and Research (BMBF).

\section{References}

Aberle, H., Butz, S., Stappert, J., Weissig, H., Kemler, R., and Hoschuetzky, H. 1994. Assembly of the cadherin-catenin complex in vitro with recombinant proteins. J. Cell Sci. 107: 3655-3663.

Abu-Elmagd, M., Garcia-Morales, C., and Wheeler, G.N. 2006. Frizzled7 mediates canonical Wnt signaling in neural crest induction. Dev. Biol. 298: 285-298.

Ahn, K., Mishina, Y., Hanks, M.C., Behringer, R.R., and Crenshaw III, E.B. 2001. BMPR-IA signaling is required for the formation of the apical ectodermal ridge and dorsal-ventral patterning of the limb. Development 128: 4449-4461.

Ai, D., Fu, X., Wang, J., Lu, M.F., Chen, L., Baldini, A., Klein, W.H., and Martin, J.F. 2007. Canonical Wnt signaling functions in second heart field to promote right ventricular growth. Proc. Natl. Acad. Sci. 104: 9319-9324.

Akiyama, H., Lyons, J.P., Mori-Akiyama, Y., Yang, X., Zhang, R., Zhang, Z., Deng, J.M., Taketo, M.M., Nakamura, T., Behringer, R.R., et al. 2004. Interactions between Sox9 and $\beta$-catenin control chondrocyte differentiation. Genes \& Dev. 18: $1072-1087$.

Amit, S., Hatzubai, A., Birman, Y., Andersen, J.S., Ben-Shushan, E., Mann, M., Ben-Neriah, Y., and Alkalay, I. 2002. Axinmediated CKI phosphorylation of $\beta$-catenin at Ser 45: A molecular switch for the Wnt pathway. Genes \& Dev. 16: 10661076.

Andl, T., Reddy, S.T., Gaddapara, T., and Millar, S.E. 2002. WNT signals are required for the initiation of hair follicle development. Dev. Cell 2: 643-653.

Ang, S.J., Stump, R.J., Lovicu, F.J., and McAvoy, J.W. 2004. Spatial and temporal expression of Wnt and Dickkopf genes during murine lens development. Gene Expr. Patterns 4: 289295

Apte, U., Zeng, G., Muller, P., Tan, X., Micsenyi, A., Cieply, B., Dai, C., Liu, Y., Kaestner, K.H., and Monga, S.P. 2006. Activation of Wnt/ $\beta$-catenin pathway during hepatocyte growth factor-induced hepatomegaly in mice. Hepatology 44: 9921002.

Apte, U., Zeng, G., Thompson, M.D., Muller, P., Micsenyi, A., Cieply, B., Kaestner, K.H., and Monga, S.P. 2007. $\beta$-Catenin is critical for early postnatal liver growth. Am. J. Physiol. Gastrointest. Liver Physiol. 292: G1578-G1585. doi: 10.1152/ajpgi.00359.2006.

Arango, N.A., Szotek, P.P., Manganaro, T.F., Oliva, E., Donahoe, P.K., and Teixeira, J. 2005. Conditional deletion of $\beta$ catenin in the mesenchyme of the developing mouse uterus results in a switch to adipogenesis in the myometrium. DeV Biol. 288: 276-283.

Ashery-Padan, R., Marquardt, T., Zhou, X., and Gruss, P. 2000 Pax6 activity in the lens primordium is required for lens formation and for correct placement of a single retina in the eye. Genes \& Dev. 14: 2701-2711.

Atit, R., Sgaier, S.K., Mohamed, O.A., Taketo, M.M., Dufort, D., Joyner, A.L., Niswander, L., and Conlon, R.A. 2006. $\beta$-Catenin activation is necessary and sufficient to specify the dorsal dermal fate in the mouse. Dev. Biol. 296: 164-176.

Aulehla, A. and Herrmann, B.G. 2004. Segmentation in vertebrates: Clock and gradient finally joined. Genes \& Dev. 18: 2060-2067.

Aulehla, A., Wehrle, C., Brand-Saberi, B., Kemler, R., Gossler, A., Kanzler, B., and Herrmann, B.G. 2003. Wnt3a plays a major role in the segmentation clock controlling somitogenesis. Dev. Cell 4: 395-406.

Aulehla, A., Wiegraebe, W., Baubet, V., Wahl, M.B., Deng, C., Taketo, M., Lewandoski, M., and Pourquie, O. 2008. A $\beta$ catenin gradient links the clock and wavefront systems in mouse embryo segmentation. Nat. Cell Biol. 10: 186-193.

Backman, M., Machon, O., Mygland, L., van den Bout, C.J., Zhong, W., Taketo, M.M., and Krauss, S. 2005. Effects of canonical Wnt signaling on dorso-ventral specification of the mouse telencephalon. Dev. Biol. 279: 155-168.

Bailey, A.P. and Streit, A. 2006. Sensory organs: Making and breaking the pre-placodal region. Curr. Top. Dev. Biol. 72: 167-204.

Barrow, J.R., Thomas, K.R., Boussadia-Zahui, O., Moore, R., Kemler, R., Capecchi, M.R., and McMahon, A.P. 2003. Ectodermal Wnt3/ $\beta$-catenin signaling is required for the establishment and maintenance of the apical ectodermal ridge. Genes \& Dev. 17: 394-409.

Baurand, A., Zelarayan, L., Betney, R., Gehrke, C., Dunger, S., Noack, C., Busjahn, A., Huelsken, J., Taketo, M.M., Birchmeier, W., et al. 2007. $\beta$-Catenin downregulation is required for adaptive cardiac remodeling. Circ. Res. 100: 1353-1362.

Beddington, R.S. and Robertson, E.J. 1999. Axis development and early asymmetry in mammals. Cell 96: 195-209.

Behrens, J., von Kries, J.P., Kuhl, M., Bruhn, L., Wedlich, D., Grosschedl, R., and Birchmeier, W. 1996. Functional interaction of $\beta$-catenin with the transcription factor LEF-1. $\mathrm{Na}$ ture 382: 638-642.

Behrens, J., Jerchow, B.A., Wurtele, M., Grimm, J., Asbrand, C., Wirtz, R., Kuhl, M., Wedlich, D., and Birchmeier, W. 1998. Functional interaction of an axin homolog, conductin, with $\beta$-catenin, APC, and GSK3 $\beta$. Science 280: 596-599.

Bienz, M. and Clevers, H. 2000. Linking colorectal cancer to Wnt signaling. Cell 103: 311-320.

Bierie, B., Nozawa, M., Renou, J.P., Shillingford, J.M., Morgan, F., Oka, T., Taketo, M.M., Cardiff, R.D., Miyoshi, K., Wag ner, K.U., et al. 2003. Activation of $\beta$-catenin in prostate epithelium induces hyperplasias and squamous transdifferentiation. Oncogene 22: 3875-3887.

Bilic, J., Huang, Y.L., Davidson, G., Zimmermann, T., Cruciat, C.M., Bienz, M., and Niehrs, C. 2007. Wnt induces LRP6 signalosomes and promotes dishevelled-dependent LRP6 phosphorylation. Science 316: 1619-1622.

Birchmeier, W. and Behrens, J. 1994. Cadherin expression in carcinomas: Role in the formation of cell junctions and the prevention of invasiveness. Biochim. Biophys. Acta 1198: $11-26$.

Blanpain, C. and Fuchs, E. 2006. Epidermal stem cells of the skin. Annu. Rev. Cell Dev. Biol. 22: 339-373.

Bodmer, W.F., Bailey, C.J., Bodmer, J., Bussey, H.J., Ellis, A., Gorman, P., Lucibello, F.C., Murday, V.A., Rider, S.H., 
Scambler, P., et al. 1987. Localization of the gene for familial adenomatous polyposis on chromosome 5. Nature 328: 614616.

Bonner, J., Gribble, S.L., Veien, E.S., Nikolaus, O.B., Weidinger, G., and Dorsky, R.I. 2008. Proliferation and patterning are mediated independently in the dorsal spinal cord downstream of canonical Wnt signaling. Dev. Biol. 313: 398-407.

Brault, V., Moore, R., Kutsch, S., Ishibashi, M., Rowitch, D.H., McMahon, A.P., Sommer, L., Boussadia, O., and Kemler, R. 2001. Inactivation of the $\beta$-catenin gene by Wnt1-Cre-mediated deletion results in dramatic brain malformation and failure of craniofacial development. Development 128: 1253-1264.

Bridgewater, D., Cox, B., Cain, J., Lau, A., Athaide, V., Gill, P.S., Kuure, S., Sainio, K., and Rosenblum, N.D. 2008. Canonical $\mathrm{WNT} / \beta$-catenin signaling is required for ureteric branching. Dev. Biol. 317: 83-94.

Buckingham, M., Meilhac, S., and Zaffran, S. 2005. Building the mammalian heart from two sources of myocardial cells. Nat. Rev. Genet. 6: 826-835.

Cabrera, C.V., Alonso, M.C., Johnston, P., Phillips, R.G., and Lawrence, P.A. 1987. Phenocopies induced with antisense RNA identify the wingless gene. Cell 50: 659-663.

Campos, V.E., Du, M., and Li, Y. 2004. Increased seizure susceptibility and cortical malformation in $\beta$-catenin mutant mice. Biochem. Biophys. Res. Commun. 320: 606-614.

Capdevila, J. and Izpisua Belmonte, J.C. 2001. Patterning mechanisms controlling vertebrate limb development. Annu. Rev. Cell Dev. Biol. 17: 87-132.

Capecchi, M. 1990. Gene targeting. How efficient can you get? Nature 348: 109.

Carroll, T.J., Park, J.S., Hayashi, S., Majumdar, A., and McMahon, A.P. 2005. Wnt9b plays a central role in the regulation of mesenchymal to epithelial transitions underlying organogenesis of the mammalian urogenital system. Dev. Cell 9: 283-292.

Cha, K.B., Douglas, K.R., Potok, M.A., Liang, H., Jones, S.N., and Camper, S.A. 2004. WNT5A signaling affects pituitary gland shape. Mech. Dev. 121: 183-194.

Chan, E.F., Gat, U., McNiff, J.M., and Fuchs, E. 1999. A common human skin tumour is caused by activating mutations in $\beta$-catenin. Nat. Genet. 21: 410-413.

Chang, C. and Hemmati-Brivanlou, A. 1998. Neural crest induction by Xwnt7B in Xenopus. Dev. Biol. 194: 129-134.

Chang, H., Gao, F., Guillou, F., Taketo, M.M., Huff, V., and Behringer, R.R. 2008. Wt1 negatively regulates $\beta$-catenin signaling during testis development. Development 135: 18751885.

Chari, N.S. and McDonnell, T.J. 2007. The Sonic hedgehog signaling network in development and neoplasia. Adv. Anat. Pathol. 14: 344-352.

Chen, Y., Stump, R.J., Lovicu, F.J., and McAvoy, J.W. 2004. Expression of Frizzleds and secreted frizzled-related proteins (Sfrps) during mammalian lens development. Int. J. Dev. Biol. 48: $867-877$.

Chen, X., Shevtsov, S.P., Hsich, E., Cui, L., Haq, S., Aronovitz, M., Kerkela, R., Molkentin, J.D., Liao, R., Salomon, R.N., et al. 2006. The $\beta$-catenin/T-cell factor/lymphocyte enhancer factor signaling pathway is required for normal and stressinduced cardiac hypertrophy. Mol. Cell. Biol. 26: 4462-4473.

Chenn, A. and Walsh, C.A. 2002. Regulation of cerebral cortical size by control of cell cycle exit in neural precursors. Science 297: 365-369.

Cheon, S.S., Cheah, A.Y., Turley, S., Nadesan, P., Poon, R., Clevers, H., and Alman, B.A. 2002. $\beta$-Catenin stabilization dysregulates mesenchymal cell proliferation, motility, and invasiveness and causes aggressive fibromatosis and hyperplastic cutaneous wounds. Proc. Natl. Acad. Sci. 99: 69736978.

Chesnutt, C., Burrus, L.W., Brown, A.M., and Niswander, L. 2004. Coordinate regulation of neural tube patterning and proliferation by TGF $\beta$ and WNT activity. Dev. Biol. 274: 334-347.

Chu, E.Y., Hens, J., Andl, T., Kairo, A., Yamaguchi, T.P., Brisken, C., Glick, A., Wysolmerski, J.J., and Millar, S.E. 2004. Canonical WNT signaling promotes mammary placode development and is essential for initiation of mammary gland morphogenesis. Development 131: 4819-4829.

Clarke, A.R. 2006. Wnt signalling in the mouse intestine. Oncogene 25: 7512-7521.

Clevers, H. 2006. Wnt/ $\beta$-catenin signaling in development and disease. Cell 127: 469-480.

Cohen, E.D., Wang, Z., Lepore, J.J., Lu, M.M., Taketo, M.M., Epstein, D.J., and Morrisey, E.E. 2007. Wnt/ $\beta$-catenin signaling promotes expansion of Isl-1-positive cardiac progenitor cells through regulation of FGF signaling. J. Clin. Invest. 117: 1794-1804.

Cole, M.F., Johnstone, S.E., Newman, J.J., Kagey, M.H., and Young, R.A. 2008. Tcf3 is an integral component of the core regulatory circuitry of embryonic stem cells. Genes \& Dev. 22: 746-755.

Costantini, F. 2006. Renal branching morphogenesis: Concepts, questions, and recent advances. Differentiation 74: 402-421.

Coudreuse, D. and Korswagen, H.C. 2007. The making of Wnt: New insights into Wnt maturation, sorting and secretion. Development 134: 3-12.

DasGupta, R. and Fuchs, E. 1999. Multiple roles for activated LEF/TCF transcription complexes during hair follicle development and differentiation. Development 126: 4557-4568.

Day, T.F., Guo, X., Garrett-Beal, L., and Yang, Y. 2005. Wnt/ $\beta$ catenin signaling in mesenchymal progenitors controls osteoblast and chondrocyte differentiation during vertebrate skeletogenesis. Dev. Cell 8: 739-750.

Deardorff, M.A., Tan, C., Saint-Jeannet, J.P., and Klein, P.S. 2001. A role for frizzled 3 in neural crest development. Development 128: 3655-3663.

De Langhe, S.P., Carraro, G., Tefft, D., Li, C., Xu, X., Chai, Y., Minoo, P., Hajihosseini, M.K., Drouin, J., Kaartinen, V., et al. 2008. Formation and differentiation of multiple mesenchymal lineages during lung development is regulated by $\beta$-catenin signaling. PLoS One 3: e1516. doi: 10.1371/ journal.pone.0001516.

del Barco Barrantes, I., Davidson, G., Grone, H.J., Westphal, H., and Niehrs, C. 2003. Dkk1 and noggin cooperate in mammalian head induction. Genes \& Dev. 17: 2239-2244.

Dessimoz, J., Bonnard, C., Huelsken, J., and Grapin-Botton, A. 2005. Pancreas-specific deletion of $\beta$-catenin reveals Wntdependent and Wnt-independent functions during development. Curr. Biol. 15: 1677-1683.

Deutscher, E. and Hung-Chang Yao, H. 2007. Essential roles of mesenchyme-derived $\beta$-catenin in mouse Mullerian duct morphogenesis. Dev. Biol. 307: 227-236.

Doble, B.W., Patel, S., Wood, G.A., Kockeritz, L.K., and Woodgett, J.R. 2007. Functional redundancy of GSK-3 $\alpha$ and GSK-3 $\beta$ in Wnt $/ \beta$-catenin signaling shown by using an allelic series of embryonic stem cell lines. Dev. Cell 12: 957971

Doetschman, T., Gregg, R.G., Maeda, N., Hooper, M.L., Melton, D.W., Thompson, S., and Smithies, O. 1987. Targetted correction of a mutant HPRT gene in mouse embryonic stem cells. Nature 330: $576-578$.

Dominguez, I., Itoh, K., and Sokol, S.Y. 1995. Role of glycogen 
synthase kinase $3 \beta$ as a negative regulator of dorsoventral axis formation in Xenopus embryos. Proc. Natl. Acad. Sci. 92: 8498-8502.

Dorsky, R.I., Raible, D.W., and Moon, R.T. 2000. Direct regulation of nacre, a zebrafish MITF homolog required for pigment cell formation, by the Wnt pathway. Genes \& Dev. 14: $158-162$.

Dreesen, O. and Brivanlou, A.H. 2007. Signaling pathways in cancer and embryonic stem cells. Stem Cell Rev. 3: 7-17.

Dunty Jr., W.C., Biris, K.K., Chalamalasetty, R.B., Taketo, M.M., Lewandoski, M., and Yamaguchi, T.P. 2008. Wnt3a/ $\beta$-catenin signaling controls posterior body development by coordinating mesoderm formation and segmentation. Development 135: 85-94.

Eisenberg, L.M. and Eisenberg, C.A. 2006. Wnt signal transduction and the formation of the myocardium. Dev. Biol. 293: 305-315.

Ekblom, P. 1996. Genetics of kidney development. Curr. Opin. Nephrol. Hypertens. 5: 282-287.

Evans, M.J. and Kaufman, M.H. 1981. Establishment in culture of pluripotential cells from mouse embryos. Nature 292: 154-156.

Fevr, T., Robine, S., Louvard, D., and Huelsken, J. 2007. Wnt/ $\beta$-catenin is essential for intestinal homeostasis and maintenance of intestinal stem cells. Mol. Cell. Biol. 27: 75517559.

Finch, P.W., He, X., Kelley, M.J., Uren, A., Schaudies, R.P., Popescu, N.C., Rudikoff, S., Aaronson, S.A., Varmus, H.E., and Rubin, J.S. 1997. Purification and molecular cloning of a secreted, Frizzled-related antagonist of Wnt action. Proc. Natl. Acad. Sci. 94: 6770-6775.

Fodde, R. and Brabletz, T. 2007. Wnt/ $\beta$-catenin signaling in cancer stemness and malignant behavior. Curr. Opin. Cell Biol. 19: $150-158$.

Foley, A.C. and Mercola, M. 2005. Heart induction by Wnt antagonists depends on the homeodomain transcription factor Hex. Genes \& Dev. 19: 387-396.

Frasch, M. 1995. Induction of visceral and cardiac mesoderm by ectodermal Dpp in the early Drosophila embryo. Nature 374: 464-467.

Fritzsch, B., Nichols, D.H., Echelard, Y., and McMahon, A.P. 1995. Development of midbrain and anterior hindbrain ocular motoneurons in normal and Wnt-1 knockout mice. $J$. Neurobiol. 27: 457-469.

$\mathrm{Fu}, \mathrm{X}$. , Sun, H., Klein, W.H., and $\mathrm{Mu}, \mathrm{X} .2006$. $\beta$-Catenin is essential for lamination but not neurogenesis in mouse retinal development. Dev. Biol. 299: 424-437.

Gammill, L.S. and Bronner-Fraser, M. 2003. Neural crest specification: Migrating into genomics. Nature Reviews 4: 795805.

Gao, X., Arlotta, P., Macklis, J.D., and Chen, J. 2007. Conditional knock-out of $\beta$-catenin in postnatal-born dentate gyrus granule neurons results in dendritic malformation. $J$. Neurosci. 27: 14317-14325.

Garcia-Castro, M.I., Marcelle, C., and Bronner-Fraser, M. 2002. Ectodermal Wnt function as a neural crest inducer. Science 297: $848-851$

Gat, U., DasGupta, R., Degenstein, L., and Fuchs, E. 1998. De Novo hair follicle morphogenesis and hair tumors in mice expressing a truncated $\beta$-catenin in skin. Cell 95: 605-614.

Gates, J. and Peifer, M. 2005. Can 1000 reviews be wrong? Actin, $\alpha$-catenin, and adherens junctions. Cell 123: 769-772.

Giudicelli, F. and Lewis, J. 2004. The vertebrate segmentation clock. Curr. Opin. Genet. Dev. 14: 407-414.

Glass, D.A., Bialek, P., Ahn, J.D., Starbuck, M., Patel, M.S., Clevers, H., Taketo, M.M., Long, F., McMahon, A.P., Lang,
R.A., et al. 2005. Canonical Wnt signaling in differentiated osteoblasts controls osteoclast differentiation. Dev. Cell 8: 751-764.

Gounari, F., Aifantis, I., Khazaie, K., Hoeflinger, S., Harada, N., Taketo, M.M., and von Boehmer, H. 2001. Somatic activation of $\beta$-catenin bypasses pre-TCR signaling and TCR selection in thymocyte development. Nat. Immunol. 2: 863869.

Gregorieff, A. and Clevers, H. 2005. Wnt signaling in the intestinal epithelium: From endoderm to cancer. Genes \& Dev. 19: $877-890$.

Gregorieff, A., Grosschedl, R., and Clevers, H. 2004. Hindgut defects and transformation of the gastro-intestinal tract in Tcf4 $4^{-/-} / \mathrm{Tcf1}^{-/-}$embryos. EMBO I. 23: 1825-1833.

Gu, H., Marth, J.D., Orban, P.C., Mossmann, H., and Rajewsky, K. 1994. Deletion of a DNA polymerase $\beta$ gene segment in T cells using cell type-specific gene targeting. Science 265: 103-106.

Guger, K.A. and Gumbiner, B.M. 1995. $\beta$-Catenin has Wnt-like activity and mimics the Nieuwkoop signaling center in Xenopus dorsal-ventral patterning. Dev. Biol. 172: 115-125.

Guo, X., Day, T.F., Jiang, X., Garrett-Beal, L., Topol, L., and Yang, Y. 2004. Wnt/ $\beta$-catenin signaling is sufficient and necessary for synovial joint formation. Genes \& Dev. 18: 24042417.

Haegel, H., Larue, L., Ohsugi, M., Fedorov, L., Herrenknecht, K., and Kemler, R. 1995. Lack of $\beta$-catenin affects mouse development at gastrulation. Development 121: 3529-3537.

Harada, N., Tamai, Y., Ishikawa, T., Sauer, B., Takaku, K., Oshima, M., and Taketo, M.M. 1999. Intestinal polyposis in mice with a dominant stable mutation of the $\beta$-catenin gene. EMBO T. 18: 5931-5942.

Harada, N., Miyoshi, H., Murai, N., Oshima, H., Tamai, Y., Oshima, M., and Taketo, M.M. 2002. Lack of tumorigenesis in the mouse liver after adenovirus-mediated expression of a dominant stable mutant of $\beta$-catenin. Cancer Res. 62: 19711977.

Hari, L., Brault, V., Kleber, M., Lee, H.Y., Ille, F., Leimeroth, R., Paratore, C., Suter, U., Kemler, R., and Sommer, L. 2002. Lineage-specific requirements of $\beta$-catenin in neural crest development. J. Cell Biol. 159: 867-880.

Hartmann, C. 2006. A Wnt canon orchestrating osteoblastogenesis. Trends Cell Biol. 16: 151-158.

Hausmann, G., Banziger, C., and Basler, K. 2007. Helping Wingless take flight: How WNT proteins are secreted. Nat. Rev. Mol. Cell Biol. 8: 331-336.

Heiser, P.W., Lau, J., Taketo, M.M., Herrera, P.L., and Hebrok, M. 2006. Stabilization of $\beta$-catenin impacts pancreas growth Development 133: 2023-2032.

Hens, J.R., Wilson, K.M., Dann, P., Chen, X., Horowitz, M.C., and Wysolmerski, J.J. 2005. TOPGAL mice show that the canonical Wnt signaling pathway is active during bone development and growth and is activated by mechanical loading in vitro. J. Bone Miner. Res. 20: 1103-1113.

Hill, T.P., Spater, D., Taketo, M.M., Birchmeier, W., and Hartmann, C. 2005. Canonical Wnt/ $\beta$-catenin signaling prevents osteoblasts from differentiating into chondrocytes. Dev. Cell 8: $727-738$.

Hill, T.P., Taketo, M.M., Birchmeier, W., and Hartmann, C. 2006. Multiple roles of mesenchymal $\beta$-catenin during murine limb patterning. Development 133: 1219-1229.

Hogan, B.L. 1999. Morphogenesis. Cell 96: 225-233.

Holmen, S.L., Zylstra, C.R., Mukherjee, A., Sigler, R.E., Faugere, M.C., Bouxsein, M.L., Deng, L., Clemens, T.L., and Williams, B.O. 2005. Essential role of $\beta$-catenin in postnatal bone acquisition. J. Biol. Chem. 280: 21162-21168. 
Hsieh, J.C., Kodjabachian, L., Rebbert, M.L., Rattner, A., Smallwood, P.M., Samos, C.H., Nusse, R., Dawid, I.B., and Nathans, J. 1999. A new secreted protein that binds to Wnt proteins and inhibits their activities. Nature 398: 431-436.

Hu, H., Hilton, M.J., Tu, X., Yu, K., Ornitz, D.M., and Long, F. 2005. Sequential roles of Hedgehog and Wnt signaling in osteoblast development. Development 132: 49-60.

Huang, H. and He, X. 2008. Wnt/ $\beta$-catenin signaling: New (and old) players and new insights. Curr. Opin. Cell Biol. 20: 119125.

Huber, O., Krohn, M., and Kemler, R. 1997. A specific domain in $\alpha$-catenin mediates binding to $\beta$-catenin or plakoglobin. I. Cell Sci. 110: 1759-1765.

Huelsken, J., Vogel, R., Brinkmann, V., Erdmann, B., Birchmeier, C., and Birchmeier, W. 2000. Requirement for $\beta$-catenin in anterior-posterior axis formation in mice. $I$. Cell Biol. 148: 567-578.

Huelsken, J., Vogel, R., Erdmann, B., Cotsarelis, G., and Birchmeier, W. 2001. $\beta$-Catenin controls hair follicle morphogenesis and stem cell differentiation in the skin. Cell 105: 533545 .

Hulsken, J., Birchmeier, W., and Behrens, J. 1994. E-cadherin and APC compete for the interaction with $\beta$-catenin and the cytoskeleton. J. Cell Biol. 127: 2061-2069.

Hunter, T. 1997. Oncoprotein networks. Cell 88: 333-346.

Iglesias, D.M., Hueber, P.A., Chu, L., Campbell, R., Patenaude, A.M., Dziarmaga, A.J., Quinlan, J., Mohamed, O., Dufort, D., and Goodyer, P.R. 2007. Canonical WNT signaling during kidney development. Am. J. Physiol. Renal Physiol. 293: F494-F500. doi: 10.1152/ajprenal.00416.2006.

Ikeya, M. and Takada, S. 1998. Wnt signaling from the dorsal neural tube is required for the formation of the medial dermomyotome. Development 125: 4969-4976.

Ikeya, M., Lee, S.M., Johnson, J.E., McMahon, A.P., and Takada, S. 1997. Wnt signalling required for expansion of neural crest and CNS progenitors. Nature 389: 966-970.

Ille, F., Atanasoski, S., Falk, S., Ittner, L.M., Marki, D., Buchmann-Moller, S., Wurdak, H., Suter, U., Taketo, M.M., and Sommer, L. 2007. Wnt/BMP signal integration regulates the balance between proliferation and differentiation of neuroepithelial cells in the dorsal spinal cord. Dev. Biol. 304: 394408.

Imbert, A., Eelkema, R., Jordan, S., Feiner, H., and Cowin, P. 2001. $\Delta$ N89 $\beta$-catenin induces precocious development, differentiation, and neoplasia in mammary gland. J. Cell Biol. 153: $555-568$.

Ioannidis, V., Zimmer, J., Beermann, F., and Held, W. 2001. Cre recombinase-mediated inactivation of $\mathrm{H}-2 \mathrm{Dd}$ transgene expression: Evidence for partial missing self-recognition by Ly49A NK cells. J. Immunol. 167: 6256-6262.

Ireland, H., Kemp, R., Houghton, C., Howard, L., Clarke, A.R., Sansom, O.J., and Winton, D.J. 2004. Inducible Cre-mediated control of gene expression in the murine gastrointestinal tract: Effect of loss of $\beta$-catenin. Gastroenterology 126: 1236-1246.

Itaranta, P., Lin, Y., Perasaari, J., Roel, G., Destree, O., and Vainio, S. 2002. Wnt-6 is expressed in the ureter bud and induces kidney tubule development in vitro. Genesis 32: 259-268.

Ito, M., Yang, Z., Andl, T., Cui, C., Kim, N., Millar, S.E., and Cotsarelis, G. 2007. Wnt-dependent de novo hair follicle regeneration in adult mouse skin after wounding. Nature 447: 316-320.

Iwatsuki, K., Liu, H.X., Gronder, A., Singer, M.A., Lane, T.F., Grosschedl, R., Mistretta, C.M., and Margolskee, R.F. 2007. Wnt signaling interacts with $\mathrm{Shh}$ to regulate taste papilla development. Proc. Natl. Acad. Sci. 104: 2253-2258.

Jackson, A., Vayssiere, B., Garcia, T., Newell, W., Baron, R., Roman-Roman, S., and Rawadi, G. 2005. Gene array analysis of Wnt-regulated genes in C3H10T1/2 cells. Bone 36: 585598.

Järvinen, E., Salazar-Ciudad, I., Birchmeier, W., Taketo, M.M., Jernvall, J., and Thesleff, I. 2006. Continuous tooth generation in mouse is induced by activated epithelial Wnt $/ \beta$ catenin signaling. Proc. Natl. Acad. Sci. 103: 18627-18632.

Jeannet, G., Scheller, M., Scarpellino, L., Duboux, S., Gardiol, N., Back, J., Kuttler, F., Malanchi, I., Birchmeier, W., Leutz, A., et al. 2008. Long-term, multilineage hematopoiesis occurs in the combined absence of $\beta$-catenin and $\gamma$-catenin. Blood 111: 142-149.

Jessell, T.M. and Sanes, J.R. 2000. Development. The decade of the developing brain. Curr. Opin. Neurobiol. 10: 599-611.

Jho, E.H., Zhang, T., Domon, C., Joo, C.K., Freund, J.N., and Costantini, F. 2002. Wnt $/ \beta$-catenin/Tcf signaling induces the transcription of Axin2, a negative regulator of the signaling pathway. Mol. Cell. Biol. 22: 1172-1183.

Junghans, D., Hack, I., Frotscher, M., Taylor, V., and Kemler, R. 2005. $\beta$-Catenin-mediated cell-adhesion is vital for embryonic forebrain development. Dev. Dyn. 233: 528-539.

Karsenty, G. and Wagner, E.F. 2002. Reaching a genetic and molecular understanding of skeletal development. Dev. Cell 2: 389-406.

Kawakami, Y., Capdevila, J., Buscher, D., Itoh, T., Rodriguez, E.C., and Izpisua Belmonte, J.C. 2001. WNT signals control FGF-dependent limb initiation and AER induction in the chick embryo. Cell 104: 891-900.

Kazanskaya, O., Glinka, A., and Niehrs, C. 2000. The role of Xenopus dickkopf1 in prechordal plate specification and neural patterning. Development 127: 4981-4992.

Kemler, R. 1993. From cadherins to catenins: Cytoplasmic protein interactions and regulation of cell adhesion. Trends Genet. 9: 317-321.

Kemler, R., Hierholzer, A., Kanzler, B., Kuppig, S., Hansen, K., Taketo, M.M., de Vries, W.N., Knowles, B.B., and Solter, D. 2004. Stabilization of $\beta$-catenin in the mouse zygote leads to premature epithelial-mesenchymal transition in the epiblast. Development 131: 5817-5824.

Kiecker, C. and Niehrs, C. 2001. A morphogen gradient of Wnt/ $\beta$-catenin signalling regulates anteroposterior neural patterning in Xenopus. Development 128: 4189-4201.

Kim, C.H., Oda, T., Itoh, M., Jiang, D., Artinger, K.B., Chandrasekharappa, S.C., Driever, W., and Chitnis, A.B. 2000. Repressor activity of Headless/Tcf3 is essential for vertebrate head formation. Nature 407: 913-916.

Kim, B.M., Buchner, G., Miletich, I., Sharpe, P.T., and Shivdasani, R.A. 2005. The stomach mesenchymal transcription factor Barxl specifies gastric epithelial identity through inhibition of transient Wnt signaling. Dev. Cell 8: 611-622.

Kim, B.M., Miletich, I., Mao, J., McMahon, A.P., Sharpe, P.A., and Shivdasani, R.A. 2007. Independent functions and mechanisms for homeobox gene Barxl in patterning mouse stomach and spleen. Development 134: 3603-3613.

Kimura, C., Yoshinaga, K., Tian, E., Suzuki, M., Aizawa, S., and Matsuo, I. 2000. Visceral endoderm mediates forebrain development by suppressing posteriorizing signals. Dev. Biol. 225: 304-321.

Kinzler, K.W. and Vogelstein, B. 1996. Lessons from hereditary colorectal cancer. Cell 87: 159-170.

Kioussi, C., Briata, P., Baek, S.H., Rose, D.W., Hamblet, N.S., Herman, T., Ohgi, K.A., Lin, C., Gleiberman, A., Wang, J., et al. 2002. Identification of a Wnt/Dvl/ $\beta$-Catenin $\rightarrow$ Pitx2 pathway mediating cell-type-specific proliferation during de- 
velopment. Cell 111: 673-685.

Kirstetter, P., Anderson, K., Porse, B.T., Jacobsen, S.E., and Nerlov, C. 2006. Activation of the canonical Wnt pathway leads to loss of hematopoietic stem cell repopulation and multilineage differentiation block. Nat. Immunol. 7: 1048-1056.

Kishimoto, J., Burgeson, R.E., and Morgan, B.A. 2000. Wnt signaling maintains the hair-inducing activity of the dermal papilla. Genes \& Dev. 14: 1181-1185.

Klaus, A. and Birchmeier, W. 2008. Wnt signalling and its impact on development and cancer. Nat. Rev. Cancer 8: 387398.

Klaus, A., Saga, Y., Taketo, M.M., Tzahor, E., and Birchmeier, W. 2007. Distinct roles of Wnt $/ \beta$-catenin and Bmp signaling during early cardiogenesis. Proc. Natl. Acad. Sci. 104: 18531-18536.

Kobielak, K., Stokes, N., de la Cruz, J., Polak, L., and Fuchs, E. 2007. Loss of a quiescent niche but not follicle stem cells in the absence of bone morphogenetic protein signaling. Proc. Natl. Acad. Sci. 104: 10063-10068.

Koch, U., Wilson, A., Cobas, M., Kemler, R., Macdonald, H.R., and Radtke, F. 2008. Simultaneous loss of $\beta$ - and $\gamma$-catenin does not perturb hematopoiesis or lymphopoiesis. Blood 111: $160-164$.

Kondo, M., Scherer, D.C., King, A.G., Manz, M.G., and Weissman, I.L. 2001. Lymphocyte development from hematopoietic stem cells. Curr. Opin. Genet. Dev. 11: 520-526.

Korinek, V., Barker, N., Moerer, P., van Donselaar, E., Huls, G., Peters, P.J., and Clevers, H. 1998. Depletion of epithelial stem-cell compartments in the small intestine of mice lacking Tcf-4. Nat. Genet. 19: 379-383.

Kreslova, J., Machon, O., Ruzickova, J., Lachova, J., Wawrousek, E.F., Kemler, R., Krauss, S., Piatigorsky, J., and Kozmik, Z. 2007. Abnormal lens morphogenesis and ectopic lens formation in the absence of $\beta$-catenin function. Genesis 45: 157168.

Kuhl, M. 2004. The WNT/calcium pathway: Biochemical mediators, tools and future requirements. Front. Biosci. 9: 967974

Kwon, C., Arnold, J., Hsiao, E.C., Taketo, M.M., Conklin, B.R., and Srivastava, D. 2007. Canonical Wnt signaling is a positive regulator of mammalian cardiac progenitors. Proc. Nat1. Acad. Sci. 104: 10894-10899.

LaBonne, C. and Bronner-Fraser, M. 1998. Neural crest induction in Xenopus: Evidence for a two-signal model. Development 125: 2403-2414.

Lane, T.F. and Leder, P. 1997. Wnt-10b directs hypermorphic development and transformation in mammary glands of male and female mice. Oncogene 15: 2133-2144.

Larue, L., Kumasaka, M., and Goding, C.R. 2003. $\beta$-Catenin in the melanocyte lineage. Pigment Cell Res. 16: 312-317.

Lee, H.Y., Kleber, M., Hari, L., Brault, V., Suter, U., Taketo, M.M., Kemler, R., and Sommer, L. 2004. Instructive role of $\mathrm{Wnt} / \beta$-catenin in sensory fate specification in neural crest stem cells. Science 303: 1020-1023.

Leppert, M., Dobbs, M., Scambler, P., O'Connell, P., Nakamura, Y., Stauffer, D., Woodward, S., Burt, R., Hughes, J., Gardner, E., et al. 1987. The gene for familial polyposis coli maps to the long arm of chromosome 5. Science 238: 1411-1413.

Lewandoski, M. 2001. Conditional control of gene expression in the mouse. Nat. Rev. Genet. 2: 743-755.

Lewis, J.L., Bonner, J., Modrell, M., Ragland, J.W., Moon, R.T., Dorsky, R.I., and Raible, D.W. 2004. Reiterated Wnt signaling during zebrafish neural crest development. Development 131: 1299-1308.

Leyns, L., Bouwmeester, T., Kim, S.H., Piccolo, S., and De Robertis, E.M. 1997. Frzb-1 is a secreted antagonist of Wnt sig- naling expressed in the Spemann organizer. Cell 88: 747756.

Li, X.M., Dong, X.P., Luo, S.W., Zhang, B., Lee, D.H., Ting, A.K., Neiswender, H., Kim, C.H., Carpenter-Hyland, E., Gao, T.M., et al. 2008. Retrograde regulation of motoneuron differentiation by muscle $\beta$-catenin. Nat. Neurosci. 11: 262268.

Lickert, H., Kutsch, S., Kanzler, B., Tamai, Y., Taketo, M.M. and Kemler, R. 2002. Formation of multiple hearts in mice following deletion of $\beta$-catenin in the embryonic endoderm. Dev. Cell 3: 171-181.

Liebner, S., Cattelino, A., Gallini, R., Rudini, N., Iurlaro, M., Piccolo, S., and Dejana, E. 2004. $\beta$-Catenin is required for endothelial-mesenchymal transformation during heart cushion development in the mouse. I. Cell Biol. 166: 359367.

Lin, L., Cui, L., Zhou, W., Dufort, D., Zhang, X., Cai, C.L., Bu, L., Yang, L., Martin, J., Kemler, R., et al. 2007. $\beta$-Catenin directly regulates Islet1 expression in cardiovascular progenitors and is required for multiple aspects of cardiogenesis. Proc. Natl. Acad. Sci. 104: 9313-9318.

Liu, C., Li, Y., Semenov, M., Han, C., Baeg, G.H., Tan, Y., Zhang, Z., Lin, X., and He, X. 2002. Control of $\beta$-catenin phosphorylation/degradation by a dual-kinase mechanism. Cell 108: 837-847.

Liu, H., Mohamed, O., Dufort, D., and Wallace, V.A. 2003. Characterization of Wnt signaling components and activation of the Wnt canonical pathway in the murine retina Dev. Dyn. 227: 323-334.

Liu, F., Thirumangalathu, S., Gallant, N.M., Yang, S.H., StoickCooper, C.L., Reddy, S.T., Andl, T., Taketo, M.M., Dlugosz, A.A., Moon, R.T., et al. 2007. Wnt- $\beta$-catenin signaling initiates taste papilla development. Nat. Genet. 39: 106-112.

Liu, F., Chu, E.Y., Watt, B., Zhang, Y., Gallant, N.M., Andl, T., Yang, S.H., Lu, M.M., Piccolo, S., Schmidt-Ullrich, R., et al. 2008. Wnt $/ \beta$-catenin signaling directs multiple stages of tooth morphogenesis. Dev. Biol. 313: 210-224.

Logan, C.Y. and Nusse, R. 2004. The Wnt signaling pathway in development and disease. Annu. Rev. Cell Dev. Biol. 20: 781-810

Lowry, W.E., Blanpain, C., Nowak, J.A., Guasch, G., Lewis, L., and Fuchs, E. 2005. Defining the impact of $\beta$-catenin/Tcf transactivation on epithelial stem cells. Genes \& Dev. 19: 1596-1611.

Lustig, B., Jerchow, B., Sachs, M., Weiler, S., Pietsch, T., Karsten, U., van de Wetering, M., Clevers, H., Schlag, P.M., Birchmeier, W., et al. 2002. Negative feedback loop of Wnt signaling through upregulation of conductin/axin2 in colorectal and liver tumors. Mol. Cell. Biol. 22: 1184-1193.

Lyons, J.P., Mueller, U.W., Ji, H., Everett, C., Fang, X., Hsieh, J.C., Barth, A.M., and McCrea, P.D. 2004. Wnt-4 activates the canonical $\beta$-catenin-mediated Wnt pathway and binds Frizzled-6 CRD: Functional implications of Wnt/ $\beta$-catenin activity in kidney epithelial cells. Exp. Cell Res. 298: 369387.

Lyuksyutova, A.I., Lu, C.C., Milanesio, N., King, L.A., Guo, N., Wang, Y., Nathans, J., Tessier-Lavigne, M., and Zou, Y. 2003. Anterior-posterior guidance of commissural axons by Wntfrizzled signaling. Science 302: 1984-1988.

Machon, O., van den Bout, C.J., Backman, M., Kemler, R., and Krauss, S. 2003. Role of $\beta$-catenin in the developing cortical and hippocampal neuroepithelium. Neuroscience 122: 129143

Majumdar, A., Vainio, S., Kispert, A., McMahon, J., and McMahon, A.P. 2003. Wnt11 and Ret/Gdnf pathways cooperate in regulating ureteric branching during metanephric kidney de- 
velopment. Development 130: 3175-3185.

Mak, K.K., Chen, M.H., Day, T.F., Chuang, P.T., and Yang, Y. 2006. Wnt/ $\beta$-catenin signaling interacts differentially with Ihh signaling in controlling endochondral bone and synovial joint formation. Development 133: 3695-3707.

Malanchi, I., Peinado, H., Kassen, D., Hussenet, T., Metzger, D., Chambon, P., Huber, M., Hohl, D., Cano, A., Birchmeier, W., et al. 2008. Cutaneous cancer stem cell maintenance is dependent on $\beta$-catenin signalling. Nature 452: 650-653.

Mao, J., Wang, J., Liu, B., Pan, W., Farr III, G.H., Flynn, C., Yuan, H., Takada, S., Kimelman, D., Li, L., et al. 2001. Low-density lipoprotein receptor-related protein-5 binds to Axin and regulates the canonical Wnt signaling pathway. Mol. Cell 7: 801-809.

Maretto, S., Cordenonsi, M., Dupont, S., Braghetta, P., Broccoli, V., Hassan, A.B., Volpin, D., Bressan, G.M., and Piccolo, S. 2003. Mapping Wnt $/ \beta$-catenin signaling during mouse development and in colorectal tumors. Proc. Natl. Acad. Sci. 100: 3299-3304.

Marikawa, Y. and Elinson, R.P. 1998. $\beta$-TrCP is a negative regulator of $\mathrm{Wnt} / \beta$-catenin signaling pathway and dorsal axis formation in Xenopus embryos. Mech. Dev. 77: 75-80.

Marose, T.D., Merkel, C.E., McMahon, A.P., and Carroll, T.J. 2008. $\beta$-Catenin is necessary to keep cells of ureteric bud/ Wolffian duct epithelium in a precursor state. Dev. Biol. 314: 112-126.

Marvin, M.J., Di Rocco, G., Gardiner, A., Bush, S.M., and Lassar, A.B. 2001. Inhibition of Wnt activity induces heart formation from posterior mesoderm. Genes \& Dev. 15: 316-327.

McMahon, A.P. and Bradley, A. 1990. The Wnt-1 (int-1) protooncogene is required for development of a large region of the mouse brain. Cell 62: 1073-1085.

McMahon, A.P. and Moon, R.T. 1989. Ectopic expression of the proto-oncogene int-1 in Xenopus embryos leads to duplication of the embryonic axis. Cell 58: 1075-1084.

McMahon, A.P., Joyner, A.L., Bradley, A., and McMahon, J.A. 1992. The midbrain-hindbrain phenotype of Wnt- $1^{-} / \mathrm{Wnt}-1^{-}$ mice results from stepwise deletion of engrailed-expressing cells by 9.5 days postcoitum. Cell 69: 581-595.

McManus, E.J., Sakamoto, K., Armit, L.J., Ronaldson, L., Shpiro, N., Marquez, R., and Alessi, D.R. 2005. Role that phosphorylation of GSK3 plays in insulin and Wnt signalling defined by knockin analysis. EMBO J. 24: 1571-1583.

McQueeney, K., Soufer, R., and Dealy, C.N. 2002. $\beta$-Catenindependent Wnt signaling in apical ectodermal ridge induction and FGF8 expression in normal and limbless mutant chick limbs. Dev. Growth Differ. 44: 315-325.

Megason, S.G. and McMahon, A.P. 2002. A mitogen gradient of dorsal midline Wnts organizes growth in the CNS. Development 129: 2087-2098.

Merkel, C.E., Karner, C.M., and Carroll, T.J. 2007. Molecular regulation of kidney development: Is the answer blowing in the Wnt? Pediatr. Nephrol. 22: 1825-1838.

Merrill, B.J., Gat, U., DasGupta, R., and Fuchs, E. 2001. Tcf3 and Lef1 regulate lineage differentiation of multipotent stem cells in skin. Genes \& Dev. 15: 1688-1705.

Michaelson, J.S. and Leder, P. 2001. $\beta$-Catenin is a downstream effector of Wnt-mediated tumorigenesis in the mammary gland. Oncogene 20: 5093-5099.

Mikels, A.J. and Nusse, R. 2006. Wnts as ligands: Processing, secretion and reception. Oncogene 25: 7461-7468.

Millar, S.E., Willert, K., Salinas, P.C., Roelink, H., Nusse, R., Sussman, D.J., and Barsh, G.S. 1999. WNT signaling in the control of hair growth and structure. Dev. Biol. 207: 133149.

Miller, L.A., Smith, A.N., Taketo, M.M., and Lang, R.A. 2006.
Optic cup and facial patterning defects in ocular ectoderm $\beta$-catenin gain-of-function mice. $B M C$ Dev. Biol. 6: 14. doi: 10.1186/1471-213X-6-14.

Miyoshi, K. and Hennighausen, L. 2003. $\beta$-catenin: A transforming actor on many stages. Breast Cancer Res. 5: 63-68.

Miyoshi, K., Shillingford, J.M., Le Provost, F., Gounari, F., Bronson, R., von Boehmer, H., Taketo, M.M., Cardiff, R.D., Hennighausen, L., and Khazaie, K. 2002. Activation of $\beta$-catenin signaling in differentiated mammary secretory cells induces transdifferentiation into epidermis and squamous metaplasias. Proc. Natl. Acad. Sci. 99: 219-224.

Mohamed, O.A., Clarke, H.J., and Dufort, D. 2004. $\beta$-Catenin signaling marks the prospective site of primitive streak formation in the mouse embryo. Dev. Dyn. 231: 416-424.

Molenaar, M., van de Wetering, M., Oosterwegel, M., PetersonMaduro, J., Godsave, S., Korinek, V., Roose, J., Destree, O., and Clevers, H. 1996. XTcf-3 transcription factor mediates $\beta$-catenin-induced axis formation in Xenopus embryos. Cell 86: 391-399.

Morkel, M., Huelsken, J., Wakamiya, M., Ding, J., van de Wetering, M., Clevers, H., Taketo, M.M., Behringer, R.R., Shen, M.M., and Birchmeier, W. 2003. $\beta$-Catenin regulates Criptoand Wnt3-dependent gene expression programs in mouse axis and mesoderm formation. Development 130: 6283-6294.

Moser, A.R., Pitot, H.C., and Dove, W.F. 1990. A dominant mutation that predisposes to multiple intestinal neoplasia in the mouse. Science 247: 322-324.

Mucenski, M.L., Wert, S.E., Nation, J.M., Loudy, D.E., Huelsken, J., Birchmeier, W., Morrisey, E.E., and Whitsett, J.A. 2003. $\beta$-Catenin is required for specification of proximal/ distal cell fate during lung morphogenesis. J. Biol. Chem. 278: 40231-40238.

Mucenski, M.L., Nation, J.M., Thitoff, A.R., Besnard, V., Xu, Y., Wert, S.E., Harada, N., Taketo, M.M., Stahlman, M.T., and Whitsett, J.A. 2005. $\beta$-Catenin regulates differentiation of respiratory epithelial cells in vivo. Am. J. Physiol. Lung Cell. Mol. Physiol. 289: L971-L979. doi: 10.1152/ajplung. 00172.2005.

Mukhopadhyay, M., Shtrom, S., Rodriguez-Esteban, C., Chen, L., Tsukui, T., Gomer, L., Dorward, D.W., Glinka, A., Grinberg, A., Huang, S.P., et al. 2001. Dickkopf1 is required for embryonic head induction and limb morphogenesis in the mouse. Dev. Cell 1: 423-434.

Müller, T., Anlag, K., Wildner, H., Britsch, S., Treier, M., and Birchmeier, C. 2005. The bHLH factor Olig3 coordinates the specification of dorsal neurons in the spinal cord. Genes \& Dev. 19: $733-743$.

Mulroy, T., Xu, Y., and Sen, J.M. 2003. $\beta$-Catenin expression enhances generation of mature thymocytes. Int. Immunol. 15: 1485-1494.

Munemitsu, S., Albert, I., Souza, B., Rubinfeld, B., and Polakis, P. 1995. Regulation of intracellular $\beta$-catenin levels by the adenomatous polyposis coli (APC) tumor-suppressor protein. Proc. Natl. Acad. Sci. 92: 3046-3050.

Muroyama, Y., Fujihara, M., Ikeya, M., Kondoh, H., and Takada, S. 2002. Wnt signaling plays an essential role in neuronal specification of the dorsal spinal cord. Genes \& Dev. 16: 548-553.

Murtaugh, L.C., Law, A.C., Dor, Y., and Melton, D.A. 2005. $\beta$-Catenin is essential for pancreatic acinar but not islet development. Development 132: 4663-4674.

Nakamura, T., Sano, M., Songyang, Z., and Schneider, M.D. 2003. A Wnt- and $\beta$-catenin-dependent pathway for mammalian cardiac myogenesis. Proc. Natl. Acad. Sci. 100: 5834 5839 . 
Närhi, K., Järvinen, E., Birchmeier, W., Taketo, M.M., Mikkola, M.L., and Thesleff, I. 2008. Sustained epithelial $\beta$-catenin activity induces precocious hair development but disrupts hair follicle down-growth and hair shaft formation. Development 135: 1019-1028.

Nelson, W.J. and Nusse, R. 2004. Convergence of Wnt, $\beta$-catenin, and cadherin pathways. Science 303: 1483-1487.

Niemann, C., Owens, D.M., Hulsken, J., Birchmeier, W., and Watt, F.M. 2002. Expression of $\Delta$ NLef1 in mouse epidermis results in differentiation of hair follicles into squamous epidermal cysts and formation of skin tumours. Development 129: $95-109$.

Niswander, L. 2003. Pattern formation: Old models out on a limb. Nat. Rev. Genet. 4: 133-143.

Nusse, R. and Varmus, H.E. 1982. Many tumors induced by the mouse mammary tumor virus contain a provirus integrated in the same region of the host genome. Cell 31: 99-109.

Nusse, R., Brown, A., Papkoff, J., Scambler, P., Shackleford, G., McMahon, A., Moon, R., and Varmus, H. 1991. A new nomenclature for int-1 and related genes: The Wnt gene family. Cell 64: 231.

Nusslein-Volhard, C. and Wieschaus, E. 1980. Mutations affecting segment number and polarity in Drosophila. Nature 287: 795-801.

Ohtola, J., Myers, J., Akhtar-Zaidi, B., Zuzindlak, D., Sandesara, P., Yeh, K., Mackem, S., and Atit, R. 2008. $\beta$-Catenin has sequential roles in the survival and specification of ventral dermis. Development 135: 2321-2329.

Ohyama, T., Mohamed, O.A., Taketo, M.M., Dufort, D., and Groves, A.K. 2006. Wnt signals mediate a fate decision between otic placode and epidermis. Development 133: 865875.

Ohyama, T., Groves, A.K., and Martin, K. 2007. The first steps towards hearing: Mechanisms of otic placode induction. Int. J. Dev. Biol. 51: 463-472.

Okubo, T. and Hogan, B.L. 2004. Hyperactive Wnt signaling changes the developmental potential of embryonic lung endoderm. J. Biol. 3: 11. doi: 10.1186/jbiol3.

Okubo, T., Pevny, L.H., and Hogan, B.L. 2006. Sox2 is required for development of taste bud sensory cells. Genes \& Dev. 20: 2654-2659.

Olson, L.E., Tollkuhn, J., Scafoglio, C., Krones, A., Zhang, J., Ohgi, K.A., Wu, W., Taketo, M.M., Kemler, R., Grosschedl, R., et al. 2006. Homeodomain-mediated $\beta$-catenin-dependent switching events dictate cell-lineage determination. Cell 125: 593-605.

Osafune, K., Takasato, M., Kispert, A., Asashima, M., and Nishinakamura, R. 2006. Identification of multipotent progenitors in the embryonic mouse kidney by a novel colonyforming assay. Development 133: 151-161.

Osakada, F., Ooto, S., Akagi, T., Mandai, M., Akaike, A., and Takahashi, M. 2007. Wnt signaling promotes regeneration in the retina of adult mammals. J. Neurosci. 27: 4210-4219.

Oshima, M., Oshima, H., Kitagawa, K., Kobayashi, M., Itakura, C., and Taketo, M. 1995. Loss of Apc heterozygosity and abnormal tissue building in nascent intestinal polyps in mice carrying a truncated Apc gene. Proc. Natl. Acad. Sci. 92: 4482-4486.

Ouchi, Y., Tabata, Y., Arai, K., and Watanabe, S. 2005. Negative regulation of retinal-neurite extension by $\beta$-catenin signaling pathway. J. Cell Sci. 118: 4473-4483.

Park, J.S., Valerius, M.T., and McMahon, A.P. 2007. Wnt/ $\beta$ catenin signaling regulates nephron induction during mouse kidney development. Development 134: 2533-2539.

Parr, B.A. and McMahon, A.P. 1995. Dorsalizing signal Wnt-7a required for normal polarity of $\mathrm{D}-\mathrm{V}$ and $\mathrm{A}-\mathrm{P}$ axes of mouse limb. Nature 374: 350-353.

Parr, B.A., Shea, M.J., Vassileva, G., and McMahon, A.P. 1993. Mouse Wnt genes exhibit discrete domains of expression in the early embryonic CNS and limb buds. Development 119: 247-261.

Passegue, E. and Weissman, I.L. 2005. Leukemic stem cells: Where do they come from? Stem Cell Rev. 1: 181-188.

Paus, R. and Foitzik, K. 2004. In search of the 'hair cycle clock': A guided tour. Differentiation 72: 489-511.

Perea-Gomez, A., Lawson, K.A., Rhinn, M., Zakin, L., Brulet, P. Mazan, S., and Ang, S.L. 2001. Otx2 is required for visceral endoderm movement and for the restriction of posterior signals in the epiblast of the mouse embryo. Development 128: 753-765.

Plikus, M.V., Mayer, J.A., de la Cruz, D., Baker, R.E., Maini, P.K., Maxson, R., and Chuong, C.M. 2008. Cyclic dermal BMP signalling regulates stem cell activation during hair regeneration. Nature 451: 340-344.

Polakis, P. 2000. Wnt signaling and cancer. Genes \& Dev. 14: 1837-1851.

Popperl, H., Schmidt, C., Wilson, V., Hume, C.R., Dodd, J., Krumlauf, R., and Beddington, R.S. 1997. Misexpression of Cwnt8C in the mouse induces an ectopic embryonic axis and causes a truncation of the anterior neuroectoderm. Development 124: 2997-3005.

Posthaus, H., Williamson, L., Baumann, D., Kemler, R., Caldelari, R., Suter, M.M., Schwarz, H., and Muller, E. 2002. $\beta$ Catenin is not required for proliferation and differentiation of epidermal mouse keratinocytes. J. Cell Sci. 115: 45874595.

Qu, J., Zhou, J., Yi, X.P., Dong, B., Zheng, H., Miller, L.M., Wang, X., Schneider, M.D., and Li, F. 2007. Cardiac-specific haploinsufficiency of $\beta$-catenin attenuates cardiac hypertrophy but enhances fetal gene expression in response to aortic constriction. J. Mol. Cell. Cardiol. 43: 319-326.

Qyang, Y., Martin-Puig, S., Chiravuri, M., Chen, S., Xu, H., Bu, L., Jiang, X., Lin, L., Granger, A., Moretti, A., et al. 2007. The renewal and differentiation of Isl1+ cardiovascular progenitors are controlled by a Wnt/ $\beta$-catenin pathway. Cell Stem Cell 1: 165-179.

Raible, D.W. and Ragland, J.W. 2005. Reiterated Wnt and BMP signals in neural crest development. Semin. Cell Dev. Biol. 16: 673-682.

Renou, J.P., Bierie, B., Miyoshi, K., Cui, Y., Djiane, J., Reichenstein, M., Shani, M., and Hennighausen, L. 2003. Identification of genes differentially expressed in mouse mammary epithelium transformed by an activated $\beta$-catenin. Oncogene 22: 4594-4610.

Reya, T., Duncan, A.W., Ailles, L., Domen, J., Scherer, D.C., Willert, K., Hintz, L., Nusse, R., and Weissman, I.L. 2003. A role for Wnt signalling in self-renewal of haematopoietic stem cells. Nature 423: 409-414.

Riccomagno, M.M., Takada, S., and Epstein, D.J. 2005. Wntdependent regulation of inner ear morphogenesis is balanced by the opposing and supporting roles of Shh. Genes \& Dev. 19: 1612-1623.

Rijsewijk, F., Schuermann, M., Wagenaar, E., Parren, P., Weigel, D., and Nusse, R. 1987. The Drosophila homolog of the mouse mammary oncogene int- 1 is identical to the segment polarity gene wingless. Cell 50: 649-657.

Rinon, A., Lazar, S., Marshall, H., Buchmann-Moller, S., Neufeld, A., Elhanany-Tamir, H., Taketo, M.M., Sommer, L., Krumlauf, R., and Tzahor, E. 2007. Cranial neural crest cells regulate head muscle patterning and differentiation during vertebrate embryogenesis. Development 134: 3065-3075.

Robinson, G.W., Karpf, A.B., and Kratochwil, K. 1999. Regula- 
tion of mammary gland development by tissue interaction. $J$. Mammary Gland Biol. Neoplasia 4: 9-19.

Rodda, S.J. and McMahon, A.P. 2006. Distinct roles for Hedgehog and canonical Wnt signaling in specification, differentiation and maintenance of osteoblast progenitors. Development 133: 3231-3244.

Roose, J., Molenaar, M., Peterson, J., Hurenkamp, J., Brantjes, H., Moerer, P., van de Wetering, M., Destree, O., and Clevers, H. 1998. The Xenopus Wnt effector XTcf-3 interacts with Groucho-related transcriptional repressors. Nature 395: 608-612.

Rulifson, I.C., Karnik, S.K., Heiser, P.W., ten Berge, D., Chen, H., Gu, X., Taketo, M.M., Nusse, R., Hebrok, M., and Kim, S.K. 2007. Wnt signaling regulates pancreatic $\beta$ cell proliferation. Proc. Nat1. Acad. Sci. 104: 6247-6252.

Saga, Y. and Takeda, H. 2001. The making of the somite: Molecular events in vertebrate segmentation. Nat. Rev. Genet. 2: $835-845$

Saga, Y., Kitajima, S., and Miyagawa-Tomita, S. 2000. Mesp1 expression is the earliest sign of cardiovascular development. Trends Cardiovasc. Med. 10: 345-352.

Saint-Jeannet, J.P., He, X., Varmus, H.E., and Dawid, I.B. 1997. Regulation of dorsal fate in the neuraxis by Wnt-1 and Wnt3a. Proc. Natl. Acad. Sci. 94: 13713-13718.

Saito, H., Yasumoto, K., Takeda, K., Takahashi, K., Yamamoto, H., and Shibahara, S. 2003. Microphthalmia-associated transcription factor in the Wnt signaling pathway. Pigment Cell Res. 16: 261-265.

Saitoh, A., Hansen, L.A., Vogel, J.C., and Udey, M.C. 1998. Characterization of Wnt gene expression in murine skin: Possible involvement of epidermis-derived Wnt-4 in cutaneous epithelial-mesenchymal interactions. Exp. Cell Res. 243: $150-160$.

Salinas, P.C. and Nusse, R. 1992. Regional expression of the Wnt-3 gene in the developing mouse forebrain in relationship to diencephalic neuromeres. Mech. Dev. 39: 151-160.

Salomon, D., Sacco, P.A., Roy, S.G., Simcha, I., Johnson, K.R., Wheelock, M.J., and Ben-Ze'ev, A. 1997. Regulation of $\beta$ catenin levels and localization by overexpression of plakoglobin and inhibition of the ubiquitin-proteasome system. $J$. Cell Biol. 139: 1325-1335.

Sangiorgi, E. and Capecchi, M.R. 2008. Bmil is expressed in vivo in intestinal stem cells. Nat. Genet. 40: 915-920.

Sansom, O.J., Meniel, V.S., Muncan, V., Phesse, T.J., Wilkins, J.A., Reed, K.R., Vass, J.K., Athineos, D., Clevers, H., and Clarke, A.R. 2007. Myc deletion rescues Apc deficiency in the small intestine. Nature 446: 676-679.

Sasaki, T., Ito, Y., Xu, X., Han, J., Bringas Jr., P., Maeda, T., Slavkin, H.C., Grosschedl, R., and Chai, Y. 2005. LEF1 is a critical epithelial survival factor during tooth morphogenesis. Dev. Biol. 278: 130-143.

Saxen, L. 1999. What is needed for kidney differentiation and how do we find it? Int. J. Dev. Biol. 43: 377-380.

Scheller, M., Huelsken, J., Rosenbauer, F., Taketo, M.M., Birchmeier, W., Tenen, D.G., and Leutz, A. 2006. Hematopoietic stem cell and multilineage defects generated by constitutive $\beta$-catenin activation. Nat. Immunol. 7: 1037-1047.

Schier, A.F. and Talbot, W.S. 2005. Molecular genetics of axis formation in zebrafish. Annu. Rev. Genet. 39: 561-613.

Schmidt-Ott, K.M., Masckauchan, T.N., Chen, X., Hirsh, B.J., Sarkar, A., Yang, J., Paragas, N., Wallace, V.A., Dufort, D., Pavlidis, P., et al. 2007. $\beta$-Catenin/TCF/Lef controls a differentiation-associated transcriptional program in renal epithelial progenitors. Development 134: 3177-3190.

Schneider, V.A. and Mercola, M. 2001. Wnt antagonism initiates cardiogenesis in Xenopus laevis. Genes \& Dev. 15:
304-315.

Schuller, U. and Rowitch, D.H. 2007. $\beta$-Catenin function is required for cerebellar morphogenesis. Brain Res. 1140: 161169.

Schwarz-Romond, T., Fiedler, M., Shibata, N., Butler, P.J., Kikuchi, A., Higuchi, Y., and Bienz, M. 2007. The DIX domain of Dishevelled confers Wnt signaling by dynamic polymerization. Nat. Struct. Mol. Biol. 14: 484-492.

Scully, K.M. and Rosenfeld, M.G. 2002. Pituitary development: Regulatory codes in mammalian organogenesis. Science 295: 2231-2235.

Seifert, J.R. and Mlodzik, M. 2007. Frizzled/PCP signalling: A conserved mechanism regulating cell polarity and directed motility. Nat. Rev. Genet. 8: 126-138.

Sekine, S., Lan, B.Y., Bedolli, M., Feng, S., and Hebrok, M. 2006. Liver-specific loss of $\beta$-catenin blocks glutamine synthesis pathway activity and cytochrome p450 expression in mice. Hepatology 43: 817-825.

Sekine, S., Gutierrez, P.J., Lan, B.Y., Feng, S., and Hebrok, M. 2007. Liver-specific loss of $\beta$-catenin results in delayed hepatocyte proliferation after partial hepatectomy. Hepatology 45: 361-368.

Shackleton, M., Vaillant, F., Simpson, K.J., Stingl, J., Smyth, G.K., Asselin-Labat, M.L., Wu, L., Lindeman, G.J., and Visvader, J.E. 2006. Generation of a functional mammary gland from a single stem cell. Nature 439: 84-88.

Shu, W., Guttentag, S., Wang, Z., Andl, T., Ballard, P., Lu, M.M., Piccolo, S., Birchmeier, W., Whitsett, J.A., Millar, S.E., et al. 2005. Wnt/ $\beta$-catenin signaling acts upstream of $\mathrm{N}$-myc, BMP4, and FGF signaling to regulate proximal-distal patterning in the lung. Dev. Biol. 283: 226-239.

Sierra, J., Yoshida, T., Joazeiro, C.A., and Jones, K.A. 2006. The APC tumor suppressor counteracts $\beta$-catenin activation and H3K4 methylation at Wnt target genes. Genes \& Dev. 20: $586-600$

Smith, A.N., Miller, L.A., Song, N., Taketo, M.M., and Lang, R.A. 2005. The duality of $\beta$-catenin function: A requirement in lens morphogenesis and signaling suppression of lens fate in periocular ectoderm. Dev. Biol. 285: 477-489.

Smits, R., Kielman, M.F., Breukel, C., Zurcher, C., Neufeld, K., Jagmohan-Changur, S., Hofland, N., van Dijk, J., White, R., Edelmann, W., et al. 1999. Apc1638T: A mouse model delineating critical domains of the adenomatous polyposis coli protein involved in tumorigenesis and development. Genes \& Dev. 13: 1309-1321.

Sneddon, J.B. and Werb, Z. 2007. Location, location, location: The cancer stem cell niche. Cell Stem Cell 1: 607-611.

Soshnikova, N., Zechner, D., Huelsken, J., Mishina, Y., Behringer, R.R., Taketo, M.M., Crenshaw III, E.B., and Birchmeier, W. 2003. Genetic interaction between Wnt/ $\beta$-catenin and BMP receptor signaling during formation of the AER and the dorsal-ventral axis in the limb. Genes \& Dev. 17: 19631968.

Srivastava, D. 2006. Making or breaking the heart: From lineage determination to morphogenesis. Cell 126: 1037-1048.

Staal, F.J. and Clevers, H.C. 2005. WNT signalling and haematopoiesis: A WNT-WNT situation. Nat. Rev. Immunol. 5: 21-30.

Stanger, B.Z., Tanaka, A.J., and Melton, D.A. 2007. Organ size is limited by the number of embryonic progenitor cells in the pancreas but not the liver. Nature 445: 886-891.

Stark, K., Vainio, S., Vassileva, G., and McMahon, A.P. 1994. Epithelial transformation of metanephric mesenchyme in the developing kidney regulated by Wnt-4. Nature 372: 679683.

Streit, A. 2001. Origin of the vertebrate inner ear: Evolution and 
induction of the otic placode. J. Anat. 199: 99-103.

Stump, R.J., Ang, S., Chen, Y., von Bahr, T., Lovicu, F.J., Pinson, K., de Iongh, R.U., Yamaguchi, T.P., Sassoon, D.A., and McAvoy, J.W. 2003. A role for Wnt $/ \beta$-catenin signaling in lens epithelial differentiation. Dev. Biol. 259: 48-61.

Su, L.K., Kinzler, K.W., Vogelstein, B., Preisinger, A.C., Moser A.R., Luongo, C., Gould, K.A., and Dove, W.F. 1992. Multiple intestinal neoplasia caused by a mutation in the murine homolog of the APC gene. Science 256: 668-670.

Sur, M. and Rubenstein, J.L. 2005. Patterning and plasticity of the cerebral cortex. Science 310: 805-810.

Takada, S., Stark, K.L., Shea, M.J., Vassileva, G., McMahon, J.A., and McMahon, A.P. 1994. Wnt-3a regulates somite and tailbud formation in the mouse embryo. Genes \& Dev. 8: 174-189.

Takeda, S., Yamazaki, H., Seog, D.H., Kanai, Y., Terada, S., and Hirokawa, N. 2000. Kinesin superfamily protein 3 (KIF3) motor transports fodrin-associating vesicles important for neurite building. J. Cell Biol. 148: 1255-1265.

Takeda, H., Lyle, S., Lazar, A.J., Zouboulis, C.C., Smyth, I., and Watt, F.M. 2006. Human sebaceous tumors harbor inactivating mutations in LEF1. Nat. Med. 12: 395-397.

Takeichi, M. 1991. Cadherin cell adhesion receptors as a morphogenetic regulator. Science 251: 1451-1455.

Tamai, K., Semenov, M., Kato, Y., Spokony, R., Liu, C., Katsuyama, Y., Hess, F., Saint-Jeannet, J.P., and He, X. 2000. LDL-receptor-related proteins in Wnt signal transduction. Nature 407: 530-535.

Tan, X., Behari, J., Cieply, B., Michalopoulos, G.K., and Monga, S.P. 2006. Conditional deletion of $\beta$-catenin reveals its role in liver growth and regeneration. Gastroenterology 131: $1561-1572$

Tan, X., Yuan, Y., Zeng, G., Apte, U., Thompson, M.D., Cieply, B., Stolz, D.B., Michalopoulos, G.K., Kaestner, K.H., and Monga, S.P. 2008. $\beta$-Catenin deletion in hepatoblasts disrupts hepatic morphogenesis and survival during mouse development. Hepatology 47: 1667-1679.

Temple, S. 2001. The development of neural stem cells. Nature 414: $112-117$.

Tetsu, O. and McCormick, F. 1999. $\beta$-Catenin regulates expression of cyclin D1 in colon carcinoma cells. Nature 398: 422 426.

Thomas, K.R. and Capecchi, M.R. 1990. Targeted disruption of the murine int-1 proto-oncogene resulting in severe abnormalities in midbrain and cerebellar development. Nature 346: $847-850$.

Treier, M., Gleiberman, A.S., O'Connell, S.M., Szeto, D.P., McMahon, J.A., McMahon, A.P., and Rosenfeld, M.G. 1998. Multistep signaling requirements for pituitary organogenesis in vivo. Genes \& Dev. 12: 1691-1704.

Tsukamoto, A.S., Grosschedl, R., Guzman, R.C., Parslow, T., and Varmus, H.E. 1988. Expression of the int-1 gene in transgenic mice is associated with mammary gland hyperplasia and adenocarcinomas in male and female mice. Cell 55: 619625.

Tzahor, E. and Lassar, A.B. 2001. Wnt signals from the neural tube block ectopic cardiogenesis. Genes \& Dev. 15: 255-260.

van Amerongen, R. and Berns, A. 2006. Knockout mouse models to study Wnt signal transduction. Trends Genet. 22: 678689.

van Genderen, C., Okamura, R.M., Farinas, I., Quo, R.G., Parslow, T.G., Bruhn, L., and Grosschedl, R. 1994. Development of several organs that require inductive epithelialmesenchymal interactions is impaired in LEF-1-deficient mice. Genes \& Dev. 8: 2691-2703.

Veeman, M.T., Axelrod, J.D., and Moon, R.T. 2003. A second canon. Functions and mechanisms of $\beta$-catenin-independent Wnt signaling. Dev. Cell 5: 367-377.

Veltmaat, J.M., Mailleux, A.A., Thiery, J.P., and Bellusci, S. 2003. Mouse embryonic mammogenesis as a model for the molecular regulation of pattern formation. Differentiation 71: $1-17$.

Verbeek, S., Izon, D., Hofhuis, F., Robanus-Maandag, E., te Riele, H., van de Wetering, M., Oosterwegel, M., Wilson, A., MacDonald, H.R., and Clevers, H. 1995. An HMG-box-containing T-cell factor required for thymocyte differentiation. Nature 374: 70-74.

Wang, J. and Shackleford, G.M. 1996. Murine Wnt10a and Wnt10b: Cloning and expression in developing limbs, face and skin of embryos and in adults. Oncogene 13: 1537-1544.

Weissman, I.L., Anderson, D.J., and Gage, F. 2001. Stem and progenitor cells: Origins, phenotypes, lineage commitments, and transdifferentiations. Annu. Rev. Cell Dev. Biol. 17: $387-403$

Wells, J.M. and Melton, D.A. 1999. Vertebrate endoderm development. Annu. Rev. Cell Dev. Biol. 15: 393-410.

Wells, J.M., Esni, F., Boivin, G.P., Aronow, B.J., Stuart, W., Combs, C., Sklenka, A., Leach, S.D., and Lowy, A.M. 2007. Wnt $/ \beta$-catenin signaling is required for development of the exocrine pancreas. BMC Dev. Biol. 7: 4. doi: 10.1186/1471213X-7-4.

Willert, K. and Jones, K.A. 2006. Wnt signaling: Is the party in the nucleus? Genes \& Dev. 20: 1394-1404.

Willert, K., Brown, J.D., Danenberg, E., Duncan, A.W., Weissman, I.L., Reya, T., Yates III, J.R., and Nusse, R. 2003. Wnt proteins are lipid-modified and can act as stem cell growth factors. Nature 423: 448-452.

Wilson, A. and Trumpp, A. 2006. Bone-marrow haematopoieticstem-cell niches. Nat. Rev. Immunol. 6: 93-106.

Wong, M.H., Hermiston, M.L., Syder, A.J., and Gordon, J.I. 1996. Forced expression of the tumor suppressor adenomatosis polyposis coli protein induces disordered cell migration in the intestinal epithelium. Proc. Natl. Acad. Sci. 93: 95889593.

Xu, Y., Banerjee, D., Huelsken, J., Birchmeier, W., and Sen, J.M. 2003. Deletion of $\beta$-catenin impairs $\mathrm{T}$ cell development. Nat. Immunol. 4: 1177-1182.

Yamaguchi, T.P. 2001. Heads or tails: Wnts and anterior-posterior patterning. Curr. Biol. 11: R713-R724. doi: 10.1016/ S0960-9822(01)00417-1.

Yamaguchi, Y., Hearing, V.J., Itami, S., Yoshikawa, K., and Katayama, I. 2005. Mesenchymal-epithelial interactions in the skin: Aiming for site-specific tissue regeneration. J. Dermatol. Sci. 40: 1-9.

Yanagawa, S., Matsuda, Y., Lee, J.S., Matsubayashi, H., Sese, S., Kadowaki, T., and Ishimoto, A. 2002. Casein kinase I phosphorylates the Armadillo protein and induces its degradation in Drosophila. EMBO J. 21: 1733-1742.

Yin, Y., White, A.C., Huh, S.H., Hilton, M.J., Kanazawa, H., Long, F., and Ornitz, D.M. 2008. An FGF-WNT gene regulatory network controls lung mesenchyme development. Dev. Biol. 319: 426-436.

$\mathrm{Yu}, \mathrm{Y}$. and Bradley, A. 2001. Engineering chromosomal rearrangements in mice. Nat. Rev. Genet. 2: 780-790.

Zamora, M., Manner, J., and Ruiz-Lozano, P. 2007. Epicardiumderived progenitor cells require $\beta$-catenin for coronary artery formation. Proc. Natl. Acad. Sci. 104: 18109-18114.

Zechner, D., Fujita, Y., Hulsken, J., Muller, T., Walther, I., Taketo, M.M., Crenshaw III, E.B., Birchmeier, W., and Birchmeier, C. 2003. $\beta$-Catenin signals regulate cell growth and the balance between progenitor cell expansion and differentiation in the nervous system. Dev. Biol. 258: 406-418. 
Zechner, D., Muller, T., Wende, H., Walther, I., Taketo, M.M., Crenshaw III, E.B., Treier, M., Birchmeier, W., and Birchmeier, C. 2007. Bmp and Wnt $/ \beta$-catenin signals control expression of the transcription factor Olig3 and the specification of spinal cord neurons. Dev. Biol. 303: 181-190.

Zeng, L., Fagotto, F., Zhang, T., Hsu, W., Vasicek, T.J., Perry III, W.L., Lee, J.J., Tilghman, S.M., Gumbiner, B.M., and Costantini, F. 1997. The mouse Fused locus encodes Axin, an inhibitor of the Wnt signaling pathway that regulates embryonic axis formation. Cell 90: 181-192.

Zhang, J., He, X.C., Tong, W.G., Johnson, T., Wiedemann, L.M., Mishina, Y., Feng, J.Q., and Li, L. 2006. Bone morphogenetic protein signaling inhibits hair follicle anagen induction by restricting epithelial stem/progenitor cell activation and expansion. Stem Cells 24: 2826-2839.

Zhang, Y., Goss, A.M., Cohen, E.D., Kadzik, R., Lepore, J.J., Muthukumaraswamy, K., Yang, J., Demayo, F.J., Whitsett, J.A., Parmacek, M.S., et al. 2008. A Gata6-Wnt pathway required for epithelial stem cell development and airway regeneration. Nat. Genet. 40: 862-870.

Zhao, C., Blum, J., Chen, A., Kwon, H.Y., Jung, S.H., Cook, J.M., Lagoo, A., and Reya, T. 2007. Loss of $\beta$-catenin impairs the renewal of normal and CML stem cells in vivo. Cancer Cell 12: $528-541$.

Zhao, C., Deng, W., and Gage, F.H. 2008. Mechanisms and functional implications of adult neurogenesis. Cell 132: 645-660.

Zhou, P., Byrne, C., Jacobs, J., and Fuchs, E. 1995. Lymphoid enhancer factor 1 directs hair follicle patterning and epithelial cell fate. Genes \& Dev. 9: 700-713.

Zhou, J., Qu, J., Yi, X.P., Graber, K., Huber, L., Wang, X., Gerdes, A.M., and Li, F. 2007. Upregulation of $\gamma$-catenin compensates for the loss of $\beta$-catenin in adult cardiomyocytes. Am. J. Physiol. Heart Circ. Physiol. 292: H270-H276. doi: 10.1152/ajpheart.00576.2006.

Zhu, X. and Rosenfeld, M.G. 2004. Transcriptional control of precursor proliferation in the early phases of pituitary development. Curr. Opin. Genet. Dev. 14: 567-574. 


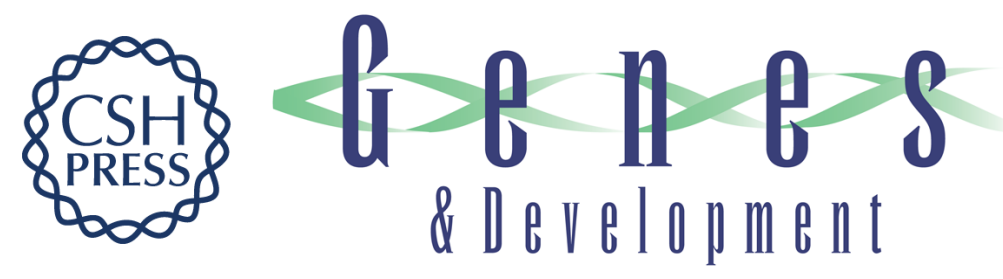

\section{Deciphering the function of canonical Wnt signals in development and disease: conditional loss- and gain-of-function mutations of $\beta$-catenin in mice}

Tamara Grigoryan, Peter Wend, Alexandra Klaus, et al.

Genes Dev. 2008, 22:

Access the most recent version at doi:10.1101/gad.1686208

References This article cites 325 articles, 127 of which can be accessed free at:

http://genesdev.cshlp.org/content/22/17/2308.full.html\#ref-list-1

License

Email Alerting
Service

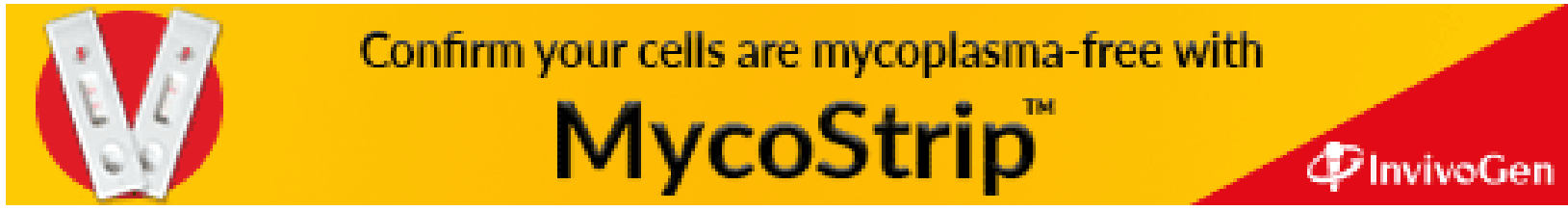

